\title{
Hepatic stellate cells - from past till present: morphology, human markers, human cell lines, behavior in normal and liver pathology
}

\author{
Rada-Teodora Sufletel ${ }^{1)}$, CARmen Stanca Melincovici ${ }^{1)}$, Bogdan-AleXandru Gheban²), \\ ZAHARIE TOADER ${ }^{3)}$, CARMEN MiHAELA MIHU ${ }^{1)}$ \\ 1) Discipline of Histology, Department of Morphological Sciences, Iuliu Hatieganu University of Medicine and Pharmacy, \\ Cluj-Napoca, Romania \\ 2) Discipline of Pathological Anatomy, Department of Morphological Sciences, Iuliu Hatieganu University of Medicine \\ and Pharmacy, Cluj-Napoca, Romania \\ 3) Department of Pathology, Prof. Dr. Octavian Fodor Regional Institute of Gastroenterology and Hepatology, \\ Cluj-Napoca, Romania
}

\begin{abstract}
Hepatic stellate cell (HSC), initially analyzed by von Kupffer, in 1876, revealed to be an extraordinary mesenchymal cell, essential for both hepatocellular function and lesions, being the hallmark of hepatic fibrogenesis and carcinogenesis. Apart from their implications in hepatic injury, HSCs play a vital role in liver development and regeneration, xenobiotic response, intermediate metabolism, and regulation of immune response. In this review, we discuss the current state of knowledge regarding HSCs morphology, human HSCs markers and human HSC cell lines. We also summarize the latest findings concerning their roles in normal and liver pathology, focusing on their impact in fibrogenesis, chronic viral hepatitis and liver tumors.
\end{abstract}

Keywords: hepatic stellate cells, vitamin A, fibrosis, chronic viral hepatitis, liver tumors.

\section{Introduction}

Hepatic stellate cell (HSC), also known as Ito cell, fat storing cell, lipocyte, perisinusoidal cell or parasinusoidal cell [1-3] was first studied by von Kupffer, who used a special staining, gold chloride technique, which detected lipid droplets of vitamin A in the stellate cell cytoplasm $[2,4]$. He called them "sternzellen" (star-shaped cells) $[2,4,5]$, their uniqueness being validated by Rothe, in $1882[2,5]$. HSCs have been highlighted by various stainings, including a lipid staining used by Ito to define the "fat storing cell" [2,6], and silver impregnation used by Suzuki to analyze "interstitial cells". Bronfenmajer et al. $[2,7]$ came with the name "lipocytes" to demonstrate their essential function in fat storage (vitamin A). Researchers like Ito, Nakane \& Wake revealed that stellate cells are capable to deposit lipids and vitamin A [2]. Kent et al. had discovered an essential function of stellate cells in liver cell repair, highlighting the proximity of these cells to collagen fibers in the injured liver $[2,8]$. The international community of investigators proposed the name of "hepatic stellate cells" to these cells, in 1996 [9]. The association between the morphological features of HSCs and the extracellular matrix (ECM) $[2,10]$ caused a huge interest in the early $1980 \mathrm{~s}$, leading to the development of stellate cell isolation methods in rats $[2,11]$, mice $[2,12]$ and human liver $[2,13,14]$.

Due to their key functions in liver homeostasis and fibrogenesis, enormous progress has been made in their study using cellular isolation methods, genetic analysis methods, flow cytometry, real-time quantitative polymerase chain reaction (PCR), confocal imaging, immunohistochemical (IHC) markers revealing their cellular origin and phenotype [2] and Raman spectroscopy $[15,16]$. Improved knowledge of these cells and their crucial roles will open new therapeutic perspectives in patients with liver diseases.

\section{Ultrastructural and morphological aspects of HSCs}

HSCs represent resident non-parenchymal cells (NPCs), fat-storing pericytes [17] existing in the subendothelial space of Disse, between the basolateral surface of hepatocytes and the antiluminal side of sinusoidal endothelial cells (SECs) $[18,19]$. In healthy liver, they account approximately $1.5 \%$ of the whole hepatic parenchyma and $1 / 3$ of the NPCs, representing $10-15 \%$ of all hepatic resident cells $[19,20]$.

The embryological origin of Ito cells was a controversial debate topic. Nowadays, most studies suggest both the endodermal (cytokeratins) $[2,21,22]$ and septum transversum mesenchyme [forkhead box f1 (Foxf1), vimentin] origin $[2,23,24]$. The theory related to the neuroectodermal origin of stellate cells due to their expression of glial markers [glial fibrillary acidic protein (GFAP), synaptophysin (SYN), neural cell adhesion molecule (N-CAM) and p75] [2, 19, 25-27] has been denied [2, 24].

This is an open-access article distributed under the terms of a Creative Commons Attribution-NonCommercial-ShareAlike 4.0 International Public License, which permits unrestricted use, adaptation, distribution and reproduction in any medium, non-commercially, provided the new creations are licensed under identical terms as the original work and the original work is properly cited. 
HSCs (from the Latin terminology "stella", meaning star) exhibit a star like shape [25, 28] and their dendritic cytoplasmic processes surround the neighboring endothelial cells $[20,28]$, just like astrocytes and podocytes embrace the terminal cerebral blood vessels, respectively the glomerular capillaries. By electron microscopy, the cellular body of stellate cell is reduced in volume, spindle shaped and contains a voluminous nucleus, oval or elongated, often compressed by lipid vacuoles of vitamin A [2]. These vacuoles usually represent $20 \%$ of the cell volume, but their distribution from one cell to another is very different [2]. In non-fixed tissues or in cell cultures, under the action of $328 \mathrm{~nm}$ light, the lipid vacuoles of vitamin A express a blue green autofluorescence that diminishes rapidly $[2,29,30]$. The amount of lipid vacuoles varies directly in proportion to the species and the amount of retinol reserves in the body $[2,31,32]$. In the stellate cell, the vacuoles of vitamin A have a mixed appearance, meaning that the variation in the number of vacuoles depends on the localization of the cells within the hepatic lobule [2, 25, 31]. The fluorescence of retinol is more pronounced around the portal and central zones [2, 31, $33,34]$. Two types of vitamin A vacuoles have been described [2, 19, 30, 35]. Type I vacuoles are membranebound vacuoles with variable sizes, that measured less than $2 \mu \mathrm{m}$ in diameter and derive from "multivesicular corpuscles", a form of lysosomes [2, 19, 30, 36, 37]. The second type vacuoles are not linked to the membrane and are larger in size, over $8 \mu \mathrm{m}$. The relationship between types I and II vacuoles and their functional differences is unclear $[2,19,30]$. According to Wake's study, type II lipid vacuoles resulted from the fusion of several type I vacuoles [35]. Furthermore, Yamamoto \& Ogawa [36] considered that type II lipid vacuoles resulted from type I vacuoles, emerging into the spaces in between hepatocytes and attaining the cytoplasmic processes of other stellate cells $[25,28]$. Cellular organelles of HSCs are those of a secretory cell, with a moderately developed rough endoplasmic reticulum, a reduced juxtanuclear Golgi apparatus and protruding dendritic cytoplasmic processes $[2,25]$. Ito cells send different types of visible cytoplasmic extensions, some of which are inter-hepatic, and others are subendothelial prolongations $[2,25,38]$. These subendothelial prolongations display microprojections, like thorns, by which the Ito cell establishes contacts with the hepatocytes [2, 38, 39]. These microprojections detect the chemotactic stimuli and transmit them to the mechanical apparatus of the cell to generate contraction $[2,38,40]$. Due to the close contacts between stellate cells, hepatocytes, Kupffer cells and sinusoids, the transport of soluble mediators and cytokines is simplified [2, 38]. In addition, stellate cells are adjacent to autonomic nerve endings $[2,38,40,41]$, which is why they respond to $\alpha$-adrenergic stimulation.

In hepatic cell injury, the morphological features of HSCs undergo important transformations [2, 28]. They lose their characteristic lipid vacuoles and become activated [19, 28, 38, 42, 43], modifying their appearance and adopting a huge flat shape. Their rough endoplasmic reticulum increases, due to the activation of protein synthesis [2, 28, 38, 44] and in the cytoplasm appear many contractile microfilaments $[2,25,28,38]$. Ito cells undergo transformation into myofibroblast (MFB)-like cells, capable of contraction, proliferation and fibrogenesis $[2,19,28,38,42]$. Thus, according to the various physiological conditions, there are two types of stellate cells: quiescent and activated $[2,19,28,38]$.

It seems like the number, morphology, and cytokine status of quiescent and activated HSCs in the liver are changed in diverse stages and circumstances of liver injury $[2,19,28]$.

\section{ㅁ Human HSCs markers}

Over the past few years, with the discovery of a wide range of specific markers for Ito cells, these cells were extremely well characterized [2]. Thus, stellate cells can be detected using different markers, like those with ectoderm origin [e.g., GFAP, nestin, neurotrophins and their receptors, nerve growth factor (NGF), brain-derived neurotrophic factor (BDNF), SYN and N-CAM]; mesoderm origin [vimentin, desmin, alpha-smooth muscle actin $(\alpha$-SMA) and hematopoietic markers] and lecithin retinol acyltransferase (LRAT) [19, 45].

In 1984, Yokoi et al. found that stellate cells of rodents expressed desmin $[2,46,47]$. Desmin, a musclespecific type III intermediate filament [19], represents a 'gold standard' for detecting HSCs in rodent liver, but its utility has been shown to be reduced due to its low expression in human Ito cells $[2,46,47]$. The positivity of desmin in HSCs has been controversial [46, 48-50]. Some studies indicate that HSCs lack desmin expression in normal and fibrotic human livers [2, 46, 48, 51, 52]. Other studies show that Ito cells express positive desmin immunoreactivity in normal $[46,50]$ and cirrhotic human liver [46, 49]. While researches revealed the existence of desmin-positive stellate cells near blood vessels in fetal liver [19, 53], transformation of HSCs into MFB has also been shown to be related with amplified desmin production and development of desmin containing intermediate filaments in a vimentin-dependent way $[19,53]$.

$\alpha$-SMA, an actin isoform, represents the only most consistent marker of activated and myofibroblastic HSCs $[2,19,28,46,54]$ because it is not present in other liver cells, except portal MFBs and vascular smooth muscle cells $[46,49,55]$. Ito cells show a strong positivity for $\alpha$-SMA in chronic liver disease (Figures 1 and 2) [46, 49, $56,57]$. Some reports have shown no $\alpha$-SMA immunoreactivity in healthy human liver $[46,55,58]$. Yet, it was proven that $\alpha$-SMA can also be expressed by quiescent HSCs in normal liver by applying very sensitive detection methods [19, 59].

In addition, HSCs express vimentin, vinculin, procollagens I, III, collagen IV, V, laminin, and fibronectin $[13,46,60-62]$. HSCs also possess neurotrophin receptors (neural markers) like GFAP, p75 nerve growth factor receptor (p75NGFR), tyrosine kinase receptor 3 (Trk-C), N-CAM, neurotrophin-3 (NT-3) and SYN [46, 63].

GFAP is an intermediate filament, expressed by astrocytes, providing support and strength for these cells $[64,65]$. It seems that HSCs also express GFAP, which is involved in the restoration of the vasculature of injured hepatic tissues during liver fibrosis $[19,66]$. Some studies revealed GFAP immunoreactivity in Ito cells during 
different stages of chronic hepatitis [46, 51]. Also, some authors described a small population of HSCs that were GFAP positive in normal human liver [46, 67]. There are studies suggesting that GFAP is a more specific marker

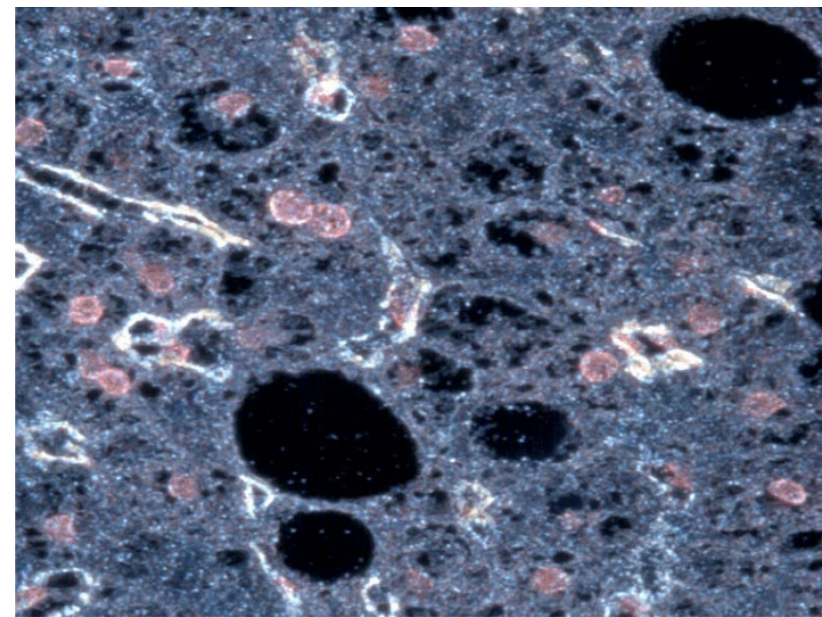

Figure 1 - Activated stellate cells show strong a-SMA cytoplasmic immunostaining in a liver biopsy of a hepatitis B-positive patient. CytoViva's Hyperspectral Microscope, image with the patented CytoViva darkfieldbased microscope, smoothing and subsetting mood. Anti$\alpha-S M A$ antibody immunostaining, $\times 200$. The image was captured at the Research Center for Advanced Medicine, MedFUTURE, Iuliu Hatieganu University of Medicine and Pharmacy, Cluj-Napoca, Romania, during my PhD training. $\alpha-S M A$ : Alpha-smooth muscle actin.

p75NGFR had shown a low expression in HSCs of healthy human livers [46]. Also, HSCs of cirrhotic livers were strongly positive for p75 [46, 51, 63, 69], while inactive HSCs were negative for p75 [46, 69].

Trk-C was positive in Ito cells of normal and injured human liver $[46,51,63]$. Some studies reported that cultured HSCs lost their Trk-C expression [46, 70].

$\mathrm{N}-\mathrm{CAM}$ was positive in periportal and intermediatezone HSCs of normal human liver [46]. Also, Ito cells of cirrhotic human liver were immunoreactive for N-CAM $[46,51]$.

NT-3 was expressed in Ito cells of normal and cirrhotic alcoholic liver [46, 51]. Also, a low immunoreactivity of NT-3 was found in hepatocytes of normal human liver $[46,63]$.

SYN represents a plasma membrane glycoprotein with affinity for neural tissues and is involved in the liberation and/or uptake of neurotransmitters in the synapse [19, 71]. It was strongly expressed by perisinusoidal HSCs in healthy liver, and also had shown enhanced immunoreactivity in chronic biliary disease and chronic viral hepatitis $\mathrm{C}[46,51,72,73]$.

Ito cells express retinol processing proteins [cellular retinol-binding protein-1 (CRBP-1), cytoglobin/stellate cell activation-associated protein (CYGB/STAP) and LRAT) and other membrane proteins [fibroblast activation protein (FAP) and platelet-derived growth factor receptor beta $(\operatorname{PDGFR} \beta)][3,46]$.

CRBP-1 is responsible for the intracellular transport of retinol [46]. Lobular stellate cells were positive for CRBP-1 and the immunoreactivity did not respond to smooth muscle cells and cholangiocytes positivity [46, than $\alpha$-SMA in detecting early active HSCs $[65,66]$. Thus, GFAP has a double utility [19], being a marker for quiescent HSCs [68] or an early marker of HSCs activation [66].

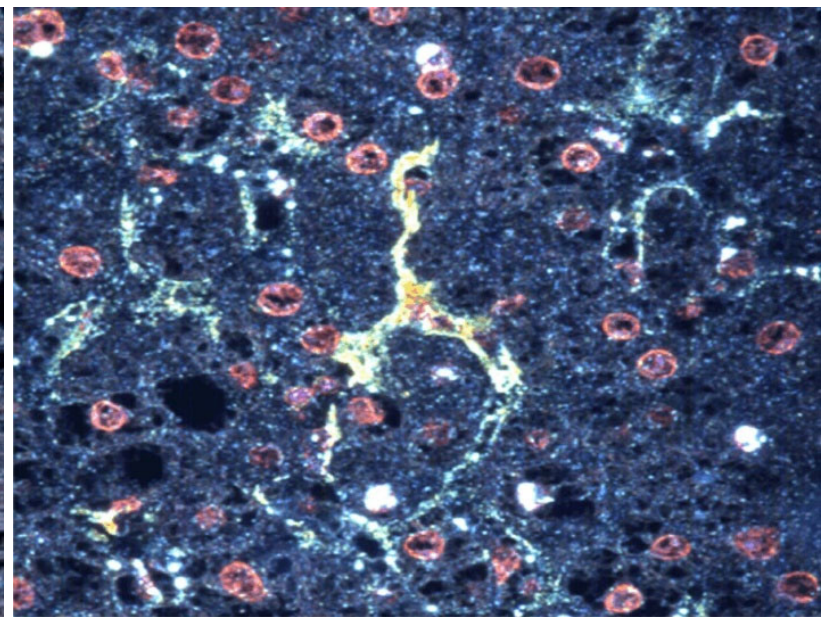

Figure 2 - Activated stellate cells show strong a-SMA cytoplasmic immunostaining in a liver biopsy of a hepatitis C-positive patient. CytoViva's Hyperspectral Microscope, image with the patented CytoViva darkfieldbased microscope, filter square root. Anti-a-SMA antibody immunostaining, $\times 200$. The image was captured at the Research Center for Advanced Medicine, MedFUTURE, Iuliu Hatieganu University of Medicine and Pharmacy, Cluj-Napoca, Romania, during my PhD training. $\alpha-S M A$ : Alpha-smooth muscle actin.

61]. The expression of CRBP-1 was low in human livers with intense fibrosis, probably because of the loss of vitamin A [46, 62].

CYGB/STAP represents a component of the globin family, revealed in 2001 as a protein related with HSCs activation $[74,75]$. It was shown that CYGB could modulate oxygen homeostasis [75]. It seems that when the oxygen homeostasis is disturbed, HSCs are activated and have main functions in liver fibrogenesis [75]. CYGB has a strong immunoreactivity in quiescent Ito cells of human livers [46]. Studies have shown that in fibrotic and cirrhotic human livers the distribution of CYGB was exclusive with the distribution of Thy-1 and fibulin-2 (FBLN2) [46, 62]. It has been revealed that cytoglobin immunoreactivity is associated with a more quiescent phenotype of HSCs and is modulated by ECM proteins via focal adhesion kinase (FAK) signaling in rat HSC-T6 cell line [46, 76].

LRAT proved to be a quiescent HSC marker in human hepatic tissue $[46,58]$. LRAT is an enzyme with a vital role in vitamin A metabolism within the liver [30, 46, 77] and a specific marker for HSCs $[46,78]$. A study reported that HSCs which express both LRAT and CRB-1 are partially responsible for portal fibrogenesis in human viral hepatitis [46, 79].

FAP is a cell surface-bound protease of the prolyl oligopeptidase gene family expressed at sites of tissue remodeling [46]. Ito cells of cirrhotic human liver were immunoreactive for FAP [46]. In normal human livers, Ito cells did not express FAP [46]. It was reported an association between the positivity of FAP and the severity of liver fibrosis $[46,80]$.

PDGFR $\beta$ was the first membrane receptor discovered 
on Ito cells [46]. Human HSCs express important levels of PDGFR $\beta$ and PDGFR $\alpha$ [46, 50, 81-84] and several studies revealed an increased immunoreactivity of PDGFR $\beta$ in Ito cells of cirrhotic human liver [46, 85].

Other markers expressed by HSCs are programmed death-ligand 1 (PD-L1) and alpha B-crystallin (ABCRYS) [46]. PD-L1 also known as B7-H1 is a co-stimulatory molecule positive only in activated HSCs [46, 86]. ABCRYS was expressed by perisinusoidally stellate cells in healthy and cirrhotic human livers $[46,51,70,87]$.

\section{a Human HSCs lines}

In order to accomplish the primary cell isolation, stellate cell clones, which share several characteristics of activated HSCs, have been created [2]. The immortalized HSCs clones have been used in a broad range of studies and have shown to be an important key in understanding HSCs biology and liver fibrosis [46]. It seems that these immortalized cell lines are perfect for genetic research due to their wide resource supply and homogeneity [2, 46].

The current HSCs lines have been produced from primary HSCs by using spontaneous immortalization during long-term culture or by transformation with the simian virus 40 large T-antigen (SV40LT) or ectopic expression of human telomerase reverse transcriptase (hTERT) $[2,46]$. All the reported cell lines proved to be nontumorigenic [46].

A wide range of cell lines have been described, below we discuss the most extensively studied human HSCs lines [2].

The first human HSC line described in the literature was the L190 cell line isolated from a human epithelioid hemangioendothelioma $[2,46,88]$. These cells share similar features with HSCs $[2,46]$. They contain lipid droplets rich in vitamin A, express $\alpha$-SMA, vimentin, matrix elements like collagen I, III, IV, V and VI, fibronectin, laminin and matrix metalloproteinases (MMPs) [2, 3, 89]. They are negative for desmin and endothelial or monocyte/ macrophage-lineage markers [46].

Other cell lines are TWNT-1 and TWNT-4, generated from LI90 line by retrovirally induced human telomerase reverse transcriptase [46]. TWNT-1 express hepatocyte growth factor (HGF), collagen type I, alpha 1 (ColI $\alpha 1$ ) and they may have a role in the assimilation of acetylated low-density lipoproteins. TWNT-4 lines are positive for PDGFR, $\alpha$-SMA, ColI $\alpha 1$ [46].

Another cell line reported is GREF-X, derived from a cirrhotic liver transfected with a plasmid containing the coding sequencing of polyoma virus large T-antigen [46]. An interesting feature is that this cell line is involved in retinol metabolism, produces matrix proteins (collagen I, IV, V and VI, fibronectin, laminin) just like L190 cells and HSCs [2, 46, 90].

A cell line extensively studied by complementary deoxyribonucleic acid (cDNA) microarray is hTERT HSC line [46]. This cell line was derivate from normal human liver using retroviral expression of hTERT [46]. Like activated human HSCs, this cell line express PDGFR $\alpha$ and PDGFR $\beta$, GFAP, ColI $\alpha 1$ and $\alpha$-SMA $[46,91,92]$. An important feature is the ability of cell clone to transdifferentiate into quiescent form under specific conditions like cultured in a matrix similar to the basement membrane [46].
Two human HSCs lines widely utilized are LX-1 and LX-2 [46]. Both were obtained from normal human liver, LX-1 by converting with SV40LT antigen and LX-2 by spontaneous immortalization in low serum culture [2, $46,93]$. These cell lines share the main functions of HSCs like storing retinol and transforming it to retinyl ester [46]. They express $\alpha$-SMA, vimentin, GFAP, PDGFR $\beta$, discoidin domain receptor 2 (DDR2), leptin receptor (Ob-RL), MMP-2, tissue inhibitor of metalloproteinase-1 (TIMP-1), membrane type 1-matrix metalloproteinase (MT1-MMP) and neuronal genes. Also, they express messenger ribonucleic acid (mRNA) for pro-ColI $\alpha 1$ and heat shock protein 47 (HSP47) [46, 94-97]. In addition, LX-2 cell line has a peculiar benefit, their relative transfectability, which improves the transfer of ectopic genes in most cell lines [2].

The most recent human HSC line was generated from normal human liver using the retrovirus SV40LT [46, 98]. By electron microscopy, the HSC-Li cells had spindle-like shape and lipid droplets in their cytoplasm [46]. This cell line express HGF, vascular endothelial growth factor receptor-1 (VEGFR-1), ColI $\alpha 1$, ColI $\alpha 2, \alpha$-SMA, PDGFR $\beta$, vimentin and transforming growth factor-beta 1 (TGF- $\beta 1$ ) [46].

\section{$a$ The roles of HSCs in healthy liver}

\section{Metabolism of vitamin A}

Vitamin A and its metabolites are indispensable in maintaining the systemic homeostasis, including normal cell division and differentiation, immunoregulation, normal reproduction and vision [30, 43, 99]. Retinyl ester, retinol, retinal and retinoic acid (RA) represent the main retinoid components of the body [100, 101].

Under normal conditions, most of body's vitamin A $(80-90 \%)$, is deposited in the liver, as lipid droplets, within the cytoplasm of HSCs [2, 30, 38, 43, 99]. Thus, HSCs have a major role in storing and transporting vitamin $\mathrm{A}$ and its metabolites.

Dietary vitamin A is absorbed in the intestinal epithelium and delivered to the liver, incorporated in chylomicrons. In the liver, the chylomicrons cross sinusoidal capillaries and reach hepatocytes [2, 30, 38, 43, 99]. Within hepatocytes, retinyl esters are converted to free retinol and then quickly transferred to HSCs or storage. A small part is left within hepatocytes [2, 30, 38, 43, 99].

Biochemically, the major components of HSCs lipid droplets are retinyl esters (the most abundant is retinyl palmitate), triglycerides, cholesterol, cholesteryl ester, phospholipids, and free fatty acids [2, 30, 38, 43, 102]. It is demonstrated that the composition, number, and size of lipid droplets are highly influenced by retinoids acquired from diet and not by dietary triglyceride intake $[2,30,43]$. In conditions of intensive dietary retinoid intake, the number and size of the lipid droplets increase, to regulate the retinoid. In conditions of low dietary retinoid intake, the number and size of lipid droplets decrease, in order to ensure tissue retinoid needs [2, 30]. Also, several studies reported important differences between the species, regarding the number of Ito cells localized in the liver and the number and size of lipid droplets contained in their cytoplasm $[2,31,103,104]$. According to these 
findings, HSCs lipid droplets are considered specialized organelles involved in the storage of retinoids [30, 104].

Many proteins involved in the metabolism of HSCs lipid droplets have been discovered, including adipocyte differentiation-related protein (ADRP), perilipin-3 (TIP47), CRBP, retinol palmitate hydrolase, cellular retinoic acid-binding protein (CRABP), bile salt-dependent and -independent retinol ester hydrolase, diacylglycerol acyltransferase 1 (DGAT1), and LRAT [2, 105].

A study conducted by Straub et al. revealed that ADRP and TIP47 are localized in HSCs lipid droplets of healthy mouse, bovine, and human liver [106]. ADRP and TIP47, components of PAT protein family, have a key role in the stabilization of lipid droplets in HSCs, just like in other cells [30].

Due to their role in storing retinoids, HSCs have high concentration of CRBP1 and LRAT. LRAT, an enzyme present in rough endoplasmic reticulum and the "multivesicular bodies" of HSCs has a crucial role in the genesis of HSCs lipid droplets, being involved in all retinyl formation within the liver $[30,58]$. HSCs also contain high levels of DGAT1 [30, 107], an enzyme responsible for triglyceride formation that is used for integration within HSCs lipid droplets [30, 107]. It was reported that DGAT1 can mediate the synthesis of retinyl ester from retinol and fatty acyl-CoA [30, 100, 108, 109].

Retinoids play a key role in modulating HSCs activation $[30,43,110,111]$. After hepatic insult, Ito cells immediately lose their lipid droplets and retinoid deposits. Also, the expression of LRAT and peroxisome proliferator-activated receptor gamma (PPAR $\gamma$ ) decrease $[30,43,110,111]$. It seems that loss of HSCs lipid droplets is the trigger in the development of hepatic disease [30]. Leo \& Lieber observed that hepatic retinoid stores were lower during the progression of alcoholic liver disease (ALD) [30, 112]. They suggested that low levels of hepatic retinoids were either caused by high degradation of the liver retinoid content or by increased mobilization of the retinoid to peripheral tissues [30, 112]. Regarding the existing reports, most retinoids are catabolized [43]. Retinol dehydrogenase 13 (RDH13), alcohol dehydrogenase 3 (ADH3) and adipose triglyceride lipase (ATGL) mediate the retinoid catabolism [43, 113-115]. It was shown that mice with low levels of RDH13 and ADH3 had a mild liver damage and fibrosis, after carbon tetrachloride $\left(\mathrm{CCl}_{4}\right)$ exposure, revealing their main role in fibrogenesis [43, 113, 114]. Also, it seems that ADH3 stimulates HSCs survival by suppressing natural killer (NK) activity [43, 114].

The contribution of retinol metabolism in HSCs activation is also highlighted by two metabolites of the RA catabolism, 9-cis-RA and 9,13-di-cis-RA, which stimulate fibrogenesis by promoting the synthesis and activation of TGF- $\beta 1[2,43,116]$. The studies regarding the roles of retinoids on HSCs and development of fibrosis are not fully understood [43]. It was reported that retinol and RA inhibited HSCs activation in culture [2]. Some studies have shown that RA treatment reduces fibrosis while others have proven that RA stimulates fibrogenesis $[43,117]$. It seems like retinoids can change activated HSCs back into the quiescent form [43, 118]. This feature could influence treatment in different liver pathologies.
Regarding the retinol mobilization, the main enzyme involved in this process is patatine-like phospholipase domain containing protein 3 (PNPLA3), which has triglyceride hydrolase, acetyl-CoA independent transacylase and retinyl esterase properties [43, 119]. The PNPLA3 $I 148 \mathrm{M}$ mutation is responsible for the loss of enzymatic activity and future changes in triglyceride metabolism, which leads to alcohol liver disease, non-alcoholic fatty liver disease (NAFLD) and hepatocellular carcinoma (HCC) $[43,120]$. The contribution of this mutation in retinol metabolism is less known [43]. This mutation could be responsible for HSCs activation, regarding the fact that expression of mutant PNPLA3 in HSCs leads to retinol loss; even so, increased lipid droplet levels were associated with high release of proinflammatory cytokines [43, 121].

Testerink et al. studied in vitro the catabolism of lipid droplets in rat HSCs using confocal Raman microspectroscopy and mass spectrometric analysis of lipids (lipidomic) [16]. They noticed that during activation, HSCs lipid droplets became smaller, but more numerous during the first seven days and the overall volume of neutral lipids was not reduced. It was shown that after seven days, HSCs had lost the majority of their retinyl esters, but preserved their triacylglycerols and cholesterol esters. Also, the investigators observed increased levels of polyunsaturated fatty acids in HSCs lipid droplets, which replaced the retinyl esters. This process supports the idea that both types of lipids influence the activation of HSCs [16]. A study conducted by Galler et al. evaluated the retinoid content of HSCs obtained from healthy mice livers and mice livers treated with lipopolysaccharide (LPS), which induces an inflammatory state, using Raman spectroscopy, in order to reflect the role of retinoid content in hepatic health [15]. They observed that retinoid state was lower in liver samples from LPS-treated mice than in liver samples from healthy mice. Thus, the HSCs retinoid content could be used as a clinical marker to assess the hepatic health state [15].

\section{The impact of HSCs in hepatic development and regeneration}

HSCs have a central role in liver regeneration, being components of the hepatic progenitor cell niche [2, 122]. This statement is suggested by the observation that mouse fetal liver mesenchymal cells, which have similar aspects of HSCs ( $\alpha$-SMA, desmin, and vimentin), stimulate the maturation of hepatoblasts by cell-cell contact in cell culture $[2,123]$. It seems like several growth factors and mitogens are synthesized by HSCs including Wnt9a protein [124], HGF [125], pleiotrophin [126], epidermal growth factor (EGF) [2, 127] and fibroblast growth factor 10 (FGF10) [128, 129]. All of them have a great contribution in the hepatocyte's proliferation through organ development and regeneration [130].

HSCs are implicated in hepatoblast differentiation by establishing cell-cell contact with hepatic epithelial cells and by secreting ECM components which influence hepatocyte and biliary cells fate [130]. Furthermore, Ito cells have a major role in the formation of intrahepatic bile ducts during development [130, 131], idea supported by the fact that rat HSCs express Notch receptors and target genes of Notch signaling [130, 132], which are 
vital in the differentiation and morphogenesis of intrahepatic biliary epithelial cells [133]. In addition, there are reports about paracrine interactions between bile duct epithelium and either HSCs or portal fibroblasts both in culture [2,134] and in vivo [2, 135]. Another finding that highlights the involvement of HSCs in the development of intrahepatic bile ducts is represented by the expression of synemin (an intermediate filament characteristic for HSCs) in both stellate cells and bile ductular epithelial cells, in response to different liver pathologies and cholangiocarcinoma [2, 136].

HSCs may influence the growth, differentiation, or morphogenesis of all the hepatic parenchymal cells, observation supported by the close contacts during development between HSCs, endothelial cells, hematopoietic and hepatic epithelial cells [38, 130].

During angiogenesis, tight contacts between pericytes and endothelial cells represent an important process in the consolidation of vascular elements [130, 137]. HSCs are considered to be the pericytes of the liver and have a major involvement in the development of the hepatic vasculature [130, 138]. This idea is supported by the observation that in mice, lack of $\beta$-catenin in the liver mesenchyme leads to HSCs activation and the liver is occupied by dilated sinusoids [130, 139].

There are reports that highlight the role of HSCs in fetal liver hematopoiesis [130]. Their involvement in liver hematopoiesis is demonstrated by the fact that in mice without the HSCs- expressing HLX homeobox gene, fetal liver hematopoiesis is markedly affected $[130,140]$. In addition, fetal HSCs express stromal cell-derived factor $1 \alpha$ (SDF1 $\alpha$; also known as CXCL12) [141], a strong chemoattractant for hematopoietic stem cells [130]. Thus, they are responsible for the recruitment of hematopoietic stem/progenitor cells into the fetal liver [130].

Another interesting finding is that HSCs could have a pluripotent role in developing or adult liver due the fact that some of them express cluster of differentiation 133 (CD133), which is a stem cell marker [2, 142]. Furthermore, it was discovered that CD133 is marker of stem-like cells in several tissues [143, 144], including colon cancer $[145,146]$.

In addition to their key role in hepatic development, there are numerous reports that HSCs represent the hallmarks of the hepatic regenerative process in adult liver [130]. Knowing the mechanisms of liver regeneration is vital for developing new strategies of differentiating and propagating hepatocytes in vitro, also for promoting hepatic recovery and increasing survival after acute liver failure, liver transplantation, or resection [130]. The most familiar and usual method to explore liver regeneration is partial hepatectomy $(\mathrm{PH})[130,147-149]$. After this procedure, liver regeneration is obtained by the proliferation of residual hepatocytes and takes place in the absence of inflammation or necrosis $[2,148]$. If the proliferation of hepatocytes collapse, it looks like liver regeneration is generated by the activation of other types of cells like oval cells or liver progenitor cells [2, 148].

Activated HSCs are involved in liver regeneration by secreting angiogenetic factors, also cytokines, that mediate endothelial cell and hepatocyte proliferation and by remodeling ECM elements [2, 130, 150]. At initial stages of liver regeneration, Ito cells stimulate the proliferation of liver progenitor cells and hepatocytes [130]. Latest reports reveal the possibility that HSCs could pass through a mesenchymal-to-epithelial transition to become liver progenitor cells and give rise to hepatocytes [130, 151].

The contribution of HSCs in hepatic regeneration is supported by the observation that suppressing activated HSCs using gliotoxin [152, 153] and L-cysteine [154] stops normal regenerative responses of both hepatocytes and oval cells in Acetaminophen and 2-Acetylaminofluorene (2-AAF)/PH-induced liver injuries [130]. Also, Foxf1+/- (forkhead transcription factor) mice treated with $\mathrm{CCl}_{4}$ reveal low HSCs activation and increase hepatocyte necrosis during the regenerative period $[23,130]$. It seems that activated HSCs secrete a wide range of cytokines and chemokines $[2,130]$, which could directly influence the proliferation of liver progenitor cells and hepatocytes or could indirectly stimulate liver regeneration by SECs and immune cells [130]. It was demonstrated that HSCs isolated from rats during initial liver regeneration after 2-AAF/PH injury produce high levels of HGF and stimulate oval cell proliferation $[130,155]$. p75 neurotrophin receptor (p75NTR), which is expressed in human HSCs after fibrotic liver insult, could modulate the synthesis of HGF by HSCs $[130,156]$.

It was noticed that in mice, loss of p75NTR suppressed hepatocyte proliferation in vivo. p75NTR-/- HSCs could not differentiate to MFBs and did not promote hepatocyte proliferation. In addition, suppression of p75NTR signaling to the small guanosine triphosphatase Rho affects HSCs differentiation $[130,156]$. Another key factor that modulates the contacts between HSCs and hepatocytes during regeneration is hedgehog $(\mathrm{Hh})$ signaling [130, 157]. It was observed that in vivo, hepatocyte proliferation is initiated by $\mathrm{Hh}$ ligand following $\mathrm{PH}[130,158]$. In culture, activated HSCs produce Sonic hedgehog (Shh), which has an autocrine growth factor role for these cells [130, 157].

Activated HSCs have a primordial role in ECM remodeling, being the central source of MMPs and their inhibitors, associated with ECM remodeling [130]. It seems like the synthesis of cytokines and remodeling of the ECM are linked, due the fact that the ECM has the ability of sequestering biologically active molecules $[159,160]$. Besides cytokine secretion, stellate cells can regulate their role by splitting or releasing cytokines from the ECM [130].

The liver regeneration process has numerous phases that implicates induction and finalization of hepatic development. This process finishes when the liver accomplishes a propriate cellular mass $[130,161]$. HSCs secrete the best-known hepatocyte antiproliferative factor TGF- $\beta$ [162]. In the final steps of liver regeneration, HSCs suppress hepatocyte proliferation and even initiate apoptosis by secreting increased quantities of TGF- $\beta 1$ [130, 149]. It was demonstrated that in culture, serotonin enhances the expression of TGF- $\beta 1$ in mice HSCs, due the 5-hydroxytryptamine $2 \mathrm{~B}$ (5-HT2B) receptor, and 5-HT2B inhibition stimulates hepatocyte proliferation after $\mathrm{PH}$, bile duct ligation (BDL) and $\mathrm{CCl}_{4}$-induced liver insult [163]. HSCs could modulate the induction and finalization of liver 
regeneration by modifying their cytokine expression profile during this process [130].

In order to get an overview of the role of HSCs in hepatic regeneration, their particular ablation during various phases in the regenerative process is required [130]. At this moment, this process is not feasible.

Genetic methods have discovered new regeneration models like the nitroreductase/Metronidazole cell ablation system [164] and morpholino-based knockdown of a mitochondrial import gene to initiate hepatocyte death [165]. One future method is to create high-through put chemical screens in different zebrafish models of liver insult, searching drugs that influence HSCs during hepatic regeneration [166].

\section{The contribution of HSCs in liver immune} system

HSCs represent the hallmarks of hepatic immunoregulation $[2,17,167]$. This statement is supported by HSCs relationship with inflammatory cells, regulating their activity or stimulating their differentiation [2, 167]. Moreover, HSCs can behave like antigen-presenting cells (APCs), have autophagy ability, secrete many immune factors like cytokines [e.g., interleukin-17 (IL-17)] and chemokines [chemokine (C-C motif) ligand 2 (CCL2)], react to numerous immunological stimuli by expressing Toll-like receptors (TLRs) (e.g., TLR4, TLR9) and transduce signals through pathways and mediators located in immune cells, like Hh pathway or inflammasome activation [17]. In normal conditions, HSCs support immunosuppressive responses, e.g., initiation of regulatory T-cells (Tregs), T-cell apoptosis (via PD-L1) or inhibition of cytotoxic CD8 T-cells. In case of hepatic insult, HSCs detect the affected tissue and promote the activation of innate immune cells [17].

It seems like the interactions between HSCs and liver immune cells are bidirectional [19]. HSCs receive many stimuli from leukocytes, intensify these signals and in response elaborate immune mediators that regulate leukocytes behavior $[17,19]$. The main HSCs activation pathway is represented by the nuclear factor-kappa B $(\mathrm{NF}-\kappa \mathrm{B})$ that stimulates LPS or TLR4 or adenosine triphosphate (ATP)-induced cytosolic $\mathrm{Ca}^{2+}$ influx through purinergic signaling receptors like $\mathrm{P} 2 \mathrm{Y}[17,168]$.

HSCs support leukocyte recruitment and adhesion, and in addition regulate their activation within the hepatic environment by producing immunomodulatory cytokines $[19,167]$. Ito cells can increase the immune response by initiating infiltration of mono- and polymorphonuclear leukocytes [2]. HSCs modulate the recruitment of inflammatory cells, such as neutrophils, macrophages/ monocytes, NK/NKT cells, by elaborating a wide range of chemokines like CCL2 [169], CCL5 [170], CCL21 [171], CCL4 [172], C-X3-C motif chemokine ligand 1 (CX3CL1) [172-174], and others. Furthermore, most of these chemokines have the property to directly regulate the activation, differentiation, proliferation, survival, and apoptosis of leukocytes [19].

HSCs activity is influenced by particular lymphocyte populations [2]. Thus, CD8 cells have an intense fibrogenic activity via stellate cells in comparation with CD4 cells [175], observation which was supported by the fact that high amount of liver fibrosis was noticed in patients with both hepatitis $\mathrm{C}$ virus (HCV) and human immunodeficiency virus (HIV) where CD4+/CD8+ cells rate was lower than in patients with only $\mathrm{HCV}$ infection [2].

There are evidences that in vitro, activated HSCs have a marked T-cell inhibitory capacity due to increased expression of PD-L1 (also known as B7-H1 or CD274), that has a key function in suppressing adaptive immune responses $[17,86]$. The expression of PD-L1 is activated by interferon-gamma (IFN- $\gamma$ ) and contrary PD-L1 inhibition leads to the decrease of HSCs immunoregulatory activity, both in humans and mice. Quiescent HSCs do not express PD-L1 [17].

Stellate cells may act as professional APCs [176-178] that can promote lymphocyte proliferation or apoptosis $[2,179]$. This property is supported by the fact that they express components of the major histocompatibility complex (MHC class I and MHC class II), lipid presenting molecules (CD1b and CD1c), and costimulatory molecules that contribute to T-cell activation (including CD40, CD80 and CD86) [19]. Activated HSCs have the capacity to internalize macromolecules and regulate $\mathrm{T}$-cell proliferation $[19,177]$. During human fibrosis, Ito cells can play as APCs, on account of the fact that they intensively express human leukocyte antigen class II (HLA-II) and CD40 in human cirrhotic livers [19].

Several reports have demonstrated that Ito cells are involved in the activation of T-cell responses by showing lipid and protein specific antigens to CD1d, MHC-I-, and MHC-II-restricted T-cells [178]. Recently, it was proven that highly purified HSCs upregulate MHC class II only in conditions of IFN- $\gamma$ stimulation, supporting the fact that at steady state, HSCs may not have the antigen presentation and costimulatory properties [180]. It was established that, in order to act like APCs, stellate cells need RA, dendritic cells (DCs) and TGF- $\beta 1$, which promote T-lymphocytes activation and could initiate differentiation of forkhead box p3 (Foxp3)+ subpopulation [181].

This theory supports the immunomodulation role of HSCs. Increase expression of CD54 in HSCs stops the activation of naïve T-cells by DCs by limiting IL-2 and interleukin-2 receptor (IL-2R) expression on T-cells [182]. This ability of Ito cells to modulate $\mathrm{T}$-cell response could be used as an alternative mechanism to regulate T-cell suppression and tolerance in the liver [182]. All these findings show that HSCs have a primordial role in liver immunity.

The role of HSCs in xenobiotic metabolism, $\mathrm{pH}$ regulation and oxidant stress response

It was reported that HSCs contain enzymes like alcohol dehydrogenase [183] and acetaldehyde dehydrogenase [184] that contributes both in intermediary metabolism and detoxification of ethanol and xenobiotics [2].

Ito cells express different isoforms of cytochrome $\mathrm{P} 450$ [2, 19] like CYP2C11, CYP3A2, CYP2D1, CYP2S1 [185], and CYP3A [186]. It seems that during cellular activation, the activity of these enzymes is reduced [2, 187]. This finding could be essential in xenobiotic detoxification and oxidant stress response [2]. The $\alpha$-, $\mu$-, and $\pi$-isoforms of glutathione S-transferase (GST) enzymes, found in HSCs using enzymatic assay and 
Northern and Western blots [188], are fundamental for detoxification of xenobiotics and the response to oxidant stress, due to their roles in both normal liver function and response to injury [189]. In addition, stellate cells express CYGB, an endogenous peroxidase that catabolizes hydrogen peroxide and lipid hydroperoxides [74].

In vivo [2], HSCs activation initiates the accumulation of glutathione synthase [190] and mRNA for the glutathione peroxidase I, the selenium-dependent isoform [191], in stellate cells. It seems like glutathione levels could make the difference between oxidative stress and activation due to TGF- $\beta 1$ [192]. Besides that, handling of glutathione deposits in stellate cells does not influence cellular activation [190]. A particular observation is that cultureinduced stellate cell activation determinates the accumulation of glutathione, while in vivo activation does not [193]. By adding N-acetyl-L-cysteine (NAC) to stellate cells, the cellular glutathione levels are restored, which stops the stellate cell cycle and leads to the initiation of p21, a cell cycle-dependent kinase inhibitor, which promotes cell cycle arrest [194].

HSCs are equipped with regulated systems that evaluate cellular pH [195], which are associated with cellular activation [2]. Particularly, the principal intracellular $\left(\mathrm{pH}_{\mathrm{i}}\right)$ modulator in rat stellate cells is the $\mathrm{Na}^{+} / \mathrm{H}^{+}$exchanger [2]. During HSCs activation, $\mathrm{pH}_{\mathrm{i}}$ and PDGF-stimulated activity of the $\mathrm{Na}^{+} / \mathrm{H}^{+}$exchanger increase $[195,196]$.

There are a wide range of reports that reveal the crucial role of nicotinamide adenine dinucleotide phosphate (NADPH) oxidase (NOX) in regulating some pathways with a very important role in stellate cell activation, such as reactions to angiotensinogen II and PDGF, apoptosis of cellular debris, and production of oxidative stress [197]. A characteristic feature is that stellate cells express essential parts (p22 phox, gp9 $1^{\text {phox }}, \mathrm{p} 47^{\text {phox }}$, and p67 ${ }^{\text {hox }}$ ) of a nonphagocytic type of NOX that generates superoxide [198]. During stellate cell activation, the nonphagocytic form of NOX is initiated and produces superoxide by connecting angiotensinogen II (ANG II) to its receptors [199]. It seems that ANG II signaling is responsible for the phosphorylation of the p47 subunit of NOX, enhanced superoxide secretion, and stellate cell activation, reactions that are dulled in p47-/- mice [199]. It was shown that these mice had decreased fibrosis following liver insult due to BDL, confirming the biological role of this pathway.

Another interesting finding is that the phagocytic role of stellate cells towards apoptotic bodies is also connected to NOX initiation, with enhanced oxidative stress [200]. The NOX inhibitor Diphenyleneiodonium (DPI) suppresses this reaction [200]. Furthermore, NOX regulates downstream effects of PDGFR signaling, and DPI stops the proliferative effects of PDGF [198].

Synthesis of lipoproteins, growth factors, and cytokines

It seems that Ito cells produce molecules with autocrine and paracrine functions, like lipoproteins, growth factors, and cytokines [2]. Like various quiescent perivascular cells, HSCs produce apolipoprotein E (ApoE) [153, 201]. ApoE, the plasma lipoprotein involved in lipid metabolism, is highly expressed in quiescent vascular smooth muscle cells [202]. ApoE has an essential role in preserving hepatic homeostasis, theory supported by the fact that ApoE-deficient mice expressed enhanced TGF- $\beta$, monocyte chemoattractant protein-1 (MCP-1), and TIMP-1 in the liver when compared to wild-type (WT) mice $[153,203]$. It was reported that HCSs also expressed apo A-I and apo A-IV [204].

Stellate cells also produce other types of lipids like prostaglandins (PGs). PGs have key functions in liver metabolism and inflammatory response, also as neuralmediated vasoregulation [2]. At initial phases in primary culture, stellate cells of rat quickly secrete $\mathrm{PGF}_{2 \alpha}$ and $\mathrm{PGD}_{2}$ during incubation with the neurotransmitter norepinephrine or ATP [205]. In vivo, this evidence has a particular importance due to the vicinity of stellate cells to nerve terminations in healthy liver [2]. In response to ethanol stimulation, HSCs become intensively activated and secrete $\mathrm{PGI}_{2}$ and $\mathrm{PGE}_{2}$ [206]. HSCs also secrete leukotriene $\mathrm{C}_{4}$ and $\mathrm{B}_{4}$ [207]. The implications of leukotriene in the activity of HSCs are not completely elucidated [2].

HSCs secrete a wide range of growth factors and cytokines in the liver [2]. It seems like for every growth factor, stellate cells not only produce cytokines but also react to them, accenting the value of closely mediated local control of cytokine activity within the pericellular environment [2]. Stellate cells produce two strong epithelial growth factors, transforming growth factor-alpha (TGF- $\alpha$ ) and EGF, that have key functions in hepatocyte proliferation during hepatic regeneration [127, 208, 209]. Moreover, TGF $-\alpha$ and EGF promote the mitotic activity in stellate cells [2]. HGF is a stronger hepatocyte mitotic factor generated by stellate cells $[125,210]$. During acute hepatic insult, the secretion of HGF by stellate cells is reduced [125]. Stellate cells also secrete stem cell factor (SCF) in rats during liver regeneration initiated by $\mathrm{PH}$ combined with 2-AAF [211]. Furthermore, Ito cells secrete insulin-like growth factor (IGF) I and II [212, 213]. In addition, HSCs produce the strongest mitotic factor, PDGF, a dimer composed of two subunits A- and B-chain [214-216]. PDGF A-chain mRNA has been found in activated human HSCs [217]. Stellate cells produce high levels of PDGF and show also enhanced upregulation of PDGFRs, during hepatic insult [83, 218]. A fascinating model emphasizing the role of PDGF in liver is one in which a mouse with transgenic expression of PDGF-C induces the fibrogenesis process, and promotes HCC development $[2,219]$. In tardive hepatic development and during liver regeneration, stellate cells in situ secrete acidic fibroblast growth factor (aFGF), another mitotic factor [2, 220].

Stellate cells secrete macrophage colony-stimulating factor (M-CSF) and MCP-1 [221], which modulate macrophage accumulation and growth [2]. The synthesis of these macrophage growth factors could be involved in the intensification of the inflammatory and fibrogenic reactions during hepatic injury [2]. Also, HSCs promote the neutrophil inflammatory response in injured liver by secreting platelet-activating factor (PAF) [2]. PAF favors the recruitment of neutrophils and promotes their activation [222]. It was revealed that during experimental fibrosis, PAF and its receptors are initiated on stellate cells [223]. Stellate cells generate numerous chemokines, such as 
cytokine-induced neutrophil chemoattractant (CINC), a rat variant of human IL-8 [224], regulated upon activation, normal T-cell expressed and presumably secreted (RANTES) [170], C-X-C chemokine ligand 1 (CXCL1) [225], macrophage inflammatory protein-2 (MIP-2) [225] and others [226].

Stellate cells could increase the acute phase response by producing IL-6 [227, 228]. On the other hand, stellate cells also secrete anti-inflammatory cytokines like follistatin and IL-10 [2, 153]. Both cytokines have antifibrotic roles $[2,153]$. It was demonstrated that rats exposed to $\mathrm{CCl}_{4}$ and treated with follistatin presented low liver fibrosis and reduced HSCs proliferation [153]. IL-10 represents a hepatoprotective cytokine with an important antifibrotic role by decreasing collagen I expression while increasing interstitial collagenase [2]. This role of IL-10 is supported by the observation that IL-10-deficient mice acquired increase liver fibrosis after $\mathrm{CCl}_{4}$ administration [229].

Stellate cells also display various adhesion molecules, such as intercellular adhesion molecule-1 (ICAM-1) [230], vascular cell adhesion molecule-1 (VCAM-1) [231], and neural cell adhesion molecule (NCAM) [232-234]. It seems that the expression of ICAM-1 is enhanced after stellate cell activation and could be involved in lymphocyte adherence to activated stellate cells [230]. In situ studies revealed that after $\mathrm{CCl}_{4}$-induced liver injury, both ICAM-1 and VCAM-1 were upregulated [231]. ICAM and VCAM may have a role in regulating the recruitment of inflammatory cells during liver injury [2]. Stellate cells showing NCAM have been detected in the vicinity of nerve terminations in the liver [232].

Stellate cells secrete TGF- $\beta 1$, one of the most crucial cytokines after liver injury [2]. This cytokine is produced in a latent form in reaction to injury, and following its activation, has strong fibrogenic properties in both autocrine and paracrine forms, especially autocrine [2]. It was reported that TGF- $\beta 1$ was enhanced in experimental and human liver fibrosis [2]. There are several processes regulating the activation of latent TGF- $\beta 1$ like cell surface activation after binding to cell-surface mannose-6-phosphate/IGF-II receptor [235] or binding to several proteins secreted by stellate cells [236], including $\alpha_{2}$-macroglobulin [237], decorin, and biglycan [2]. In addition, local plasminogen activator (PA)/plasmin is involved in the activation of latent TGF- $\beta 1$ [2].

Furthermore, Ito cells produce a growth factor regulator protein, connective tissue growth factor (CTGF) protein that favors fibrogenesis in skin, lung, and kidney. This cytokine is very increased during liver fibrogenesis [2].

Stellate cells represent an important source of endothelin-1 (ET-1) during liver injury [2]. ET-1 is a strong vasoconstrictor, which could be responsible for portal hypertension in the cirrhotic liver due to its contractile role on stellate cells and MFBs [238, 239]. Also, ET-1 favors the proliferation of early-cultured stellate cells and suppressed those completely activated [240]. On the other hand, stellate cells represent the source of nitric oxide (NO), a physiological opponent to ET-1 [241]. NO could be involved in the sustainment of microcirculation during hepatic insult [2].

In addition, stellate cells produce cystatin C [242], a serum protein filtered by the kidney and used as a sensitive marker of glomerular filtration rate [243].

\section{a The involvement of HSCs in liver pathology}

Due to their key roles in normal and injured liver, stellate cells have been characterized in numerous human diseases [2] like alcoholic steatohepatitis (ASH) [244, 245], NAFLD [2, 19, 153], hepatitis B virus (HBV) or HCV infection $[19,65,246-253]$, HCC $[2,130,153,254$ 257], cholangiocarcinoma [254], vascular disease [258], hematological malignancy [258], biliary disease [258], mucopolysaccharidosis [259], Acetaminophen overdose [260], leishmaniasis [19, 261] and schistosomiasis [19]. In this review, we discuss their behavior in the context of liver fibrosis, viral hepatitis, and liver tumors.

\section{From normal to a fibrotic liver}

The liver represents a complex organ with multiple functions like biosynthesis, metabolism, clearance, and host defense [262]. The particular and various structural and cellular composition of the liver are responsible for these specific functions [262].

From a structural point of view, the liver is composed of five components: $(i)$ hepatocytes and hepatic lobules; (ii) vascular system; (iii) hepatic sinusoidal cells; (iv) biliary tract; and (v) stroma [257, 263]. Hepatocytes and cholangiocytes are parenchymal cells with glandular, metabolic, and detoxifying roles [262]. They represent $70 \%$ of totally cells in the liver [262]. The remaining cells are the NPCs, that occupy the $30 \%$ of the liver and include endothelial cells, Kupffer cells, stellate cells, and lymphocytes [257, 262]. All of them have systemic and local functions [262]; systemically, these specific cells are involved in blood filtration, molecular cleaning, also in inflammatory and immune responses, and locally they ensure the liver microcirculation, ECM structure and, in addition, liver tissue replacement and regeneration [262, 264].

During hepatic injuries, the liver histological structure is replaced with a scar tissue [257]. During the fibrotic process, the liver parenchyma is permanently replaced with abnormal regenerative nodules, separated by rich collagen bundles, secreted by activated Ito cells [265].

Fibrosis is the main pathophysiological result of chronic liver injury and represents the most frequent path responsible for liver failure and for most of the clinical complications of end-stage liver disease [28].

\section{Liver fibrosis and HSCs activation}

Fibrosis represents an active and permanent process that takes place in response to a chronic injury and affects the homeostasis of the ECM [28, 43]. The most common types of fibrotic liver disorder are ALD, NAFLD, which usually develops into non-alcoholic steatohepatitis (NASH) [266], and viral hepatitis [43].

Fibrosis refers to an abnormal accumulation of fibrillar ECM components, like collagen I and III, in the space of Disse [267, 268]. The accumulation of ECM components in the space of Disse is responsible for the impairment of the normal, fenestrated liver sinusoids in a process defined as capillarization of these vessels [28, 268, 269]. These alterations affect the normal nutrient transport between sinusoidal blood and neighboring cells, particularly hepatocytes, inducing functional perturbation 
$[268,269]$. The fibrotic process is associated with immune infiltrations and changes in angiogenesis [43]. All these processes are responsible for the disruption of the normal liver architecture, for the liver elasticity loss, and finally for the alteration in organ structure and function [43, $270]$.

The main cell type involved in liver fibrogenesis is represented by HSCs [2, 28, 43, 153, 271]. In response to hepatic injury, Ito cells become activated, and they convert from inactive rich vitamin A cells into MFBlike cells with proliferative, contractile, migratory, and fibrogenic properties [2, 28, 42, 43, 45].

During activation, they lose their specific lipid droplets, gain a fibroblast-like shape, and express high levels of $\alpha$-SMA (Figures 1 and 2) and ECM elements [2, 28, 42, 43, 153, 268]. Furthermore, activated stellate cells are rich in rough endoplasmic reticulum, associated with a well-formed Golgi apparatus and development of many microfilaments bundles beneath the cell membrane [2, 19, 28, 42, 43, 153, 268]. Activation of HSCs happens in three stages: initiation, perpetuation, and resolution [2, 28, 42]. Initiation is characterized by the initial modifications in gene expression and morphology that make the cells responsive to other cytokines and stimuli $[2,28,42,43]$. The second phase, perpetuation, is the result of the stimuli effects on sustaining the activated phenotype and producing fibrosis. Perpetuation includes proliferation, contractility, fibrogenesis, matrix degradation, retinoid loss, and inflammatory cell infiltration $[2,28$, 42]. The third phase, resolution of fibrosis, comprises pathways that either promote stellate cell apoptosis, or lead to their return to the quiescent form [2, 28, 42]. During these phases, HSCs are stimulated in an autocrine and paracrine manner by various cytokines and growth factors produced by several liver resident cell types, such as Kupffer cells, hepatocytes, platelets, leukocytes, and SECs [19, 28, 153].

The best analyzed mediators that activate HSCs include PDGF, TGF- $\beta$, cell surface death receptor (Fas), apoptotic bodies, extracellular vesicles (EVs), and stiffness $[2,153$, 272, 273]. These mediators are secreted by various cell types like SECs [272], Kupffer cells [274], injured hepatocytes [275, 276], and HSCs [277].

In liver injury, Kupffer cells can influence the activation and proliferation of HSCs through cytokine secretion, including TGF- $\beta 1$, IL- 1 , TNF- $\alpha$, reactive oxygen species (ROS), and lipid peroxides [2, 43, 45]. Also, Kupffer cells promote HSCs migration by secreting PDGF [42, 153]. Moreover, Kupffer cells produce MCP-1 in a sphingosine kinase-1 (SK-1)-dependent fashion [278]. MCP-1 connects to $\mathrm{C}-\mathrm{C}$ motif chemokine receptor 2 (CCR2), which is expressed in both HSCs and Kupffer cells, causing their migration $[278,279]$ and finally hepatic fibrosis [280]. It was shown that mice treated with a specific inhibitor of SK-1 did not developed liver fibrosis in $\mathrm{CCl}_{4}$ and BDL-induced liver injuries [153, 278].

Hepatocytes, the main hepatic parenchymal cells, also contribute to the activation of HSCs [19, 43, 153]. It seems that damaged hepatocytes undergo apoptosis by a Fas-dependent mechanism and elaborate apoptotic bodies, which are swallowed by HSCs [275, 276]. This process promotes the fibrogenic activity of HSCs through the enhanced production of collagen $\alpha 1$, TGF- $\beta 1$, and $\alpha$-SMA $[153,276]$. In addition, injured hepatocytes elaborate ROS and lipid peroxides, which activate HSCs and cause hepatic fibrosis [42, 153, 281].

Another cell type involved in HSCs activation is activated or capillarized SECs [19, 28, 43, 153]. Capillarized SECs stimulate HSCs contraction by increasing ET-1 secretion and decreasing NO liberation [42, 153, 272]. SECs promote HSCs migration through the secretion of SDF-1/C-X-C motif chemokine ligand 12 (CXCL12) $[153,282]$ and the liberation of SK-1-containing EVs $[153,283]$. Also, in liver fibrogenesis, SECs modulate fibroblast growth factor receptor 1 (FGFR1) and $\mathrm{C}-\mathrm{X}-\mathrm{C}$ motif chemokine receptor 4 (CXCR4) expressions, consolidating the fibrogenic phenotype of HSCs [153, 284].

Platelets also are involved in HSCs activation by secreting pro-fibrogenic growth factors like PDGF, TGF$\beta 1$ and EGF [19, 20, 285]. Furthermore, neutrophils are also responsible for the activation of stellate cells by secreting $\operatorname{ROS}[2,19,43,45]$. Also, it seems that lymphocytes may generate pro-fibrogenic cytokines [43].

Along SECs, Kupffer cells, hepatocytes, platelets, leucocytes, activated HSCs can also generate pro-fibrogenic cytokines, growth factors, and morphogenetic proteins, which in turn modulate and alter tissue architecture [153]. It is known that activated HSCs produce pro-fibrogenic molecules like ColI $\alpha 1$, TGF- $\beta$, and PDGF-BB [2, 153, 286]. In addition, the reduction of RA level in HSCs leads to the initiation of TGF- $\beta 1$ expression and activation of HSCs, supporting the contribution of RA in HSCs quiescence [153, 287].

It was established that bacterial LPS, has a key function in the reduction of RA signaling through the initiation of the autophagy of HSCs lipid droplets and determining the HSCs activation [153, 288]. HSCs activated by LPS initiate the secretion of interferon-beta (IFN- $\beta$ ), which favors hepatocyte apoptosis [153, 289]. Successively, apoptotic hepatocytes are involved in the activation of HSCs [153, 275, 276].

Additionally, activated HSCs and MFBs represent the source of a strong angiogenic factor, VEGF, which binds to VEGFR expressed by SECs and initiates angiogenesis in the context of fibrosis [153,290].

It was reported that activated HSCs generate PDGFR $\alpha$ enriched EVs, which have a paracrine role in stimulating in vitro cell migration and in vivo fibrogenesis [153, 277]. The PDGFR $\alpha$ enrichment in HSC-derived EVs is associated to Src homology-2 domain-containing protein tyrosine phosphatase-2 (SHP2) and it seems like hepatic fibrogenesis was highly decreased in mice treated with SHP2 inhibitor, SHP099 [153, 277].

A surprising finding is that $\mathrm{G}$ protein-coupled receptors (GPCRs) are rising as new perspectives in hepatic fibrosis [153]. It seems like activated stellate cells express proteaseactivated receptor-2 (PAR2) [153] and proliferation of HSCs and collagen accumulation were reduced by suppressing PAR2 with PZ-235 [153, 291].

Another factor involved in the activation of stellate cells is hepatic stiffness [28, 153]. This role is suggested by the fact that freshly isolated Ito cells placed on a tender substrate, preserve their lipid droplets and increase 
concentrations of PPAR $\gamma$ [153]. In contrast, HSCs drop off their lipid droplets and upregulate $\alpha$-SMA and collagen I expression, when are placed on a stiff substrate [292]. Furthermore, recently it was shown that substrate stiffness initiates HSCs activation by translocation into the nucleus of histone acetyl transferase p300, which is responsible for the upregulation transcription of HSCs activation genes [153, 273].

Activated HSCs predominantly secrete collagens type I and III and ECM proteins like fibronectin, thrombospondin-1 and proteoglycans [43]. Ito cells secrete collagen in the form of pre-procollagen [43]. In addition, activated stellate cells express and modulate the actions of various families of ECM regulatory factors. The main enzymes secreted by stellate cells are lysyl oxidase (LOX), lysyl oxidaselike (LOXL) proteins, and transglutaminase, responsible for the regulation of crosslinking of collagen in the extracellular space [43, 293-295]. HSCs expressed tissue inhibitors, including adamalysins [A disintegrin and metalloproteinases (ADAMs) and ADAM with thrombospondin motifs (ADAMTS)], meprins, etc., which may suppress the actions of MMPs, involved in the degradation of ECM at physiological $\mathrm{pH}[43,296]$.

It is well known that activated stellate cells express $\alpha$-SMA, an authentic marker of HSCs activation [2, 19, $28,42,43]$. Quantitative study of HSCs activation using $\alpha$-SMA has been demonstrated to be a helpful prognostic marker in evaluating the evolution of liver fibrosis in some hepatic diseases [28]. It was revealed that during activation, the levels of microRNA (miRNA) levels are modified [19, 297, 298]. A new microarray study of human quiescent HSCs revealed 47 downregulated and 212 upregulated miRNAs [19, 299]. It was demonstrated that let7A and let7B miRNAs modulate HSCs activation in reply to LPS and TGF- $\beta[19,300]$. Overexpression of let7 $\mathrm{A}$ and let7B suppressed myofibroblastic activation of HSCs as evident by downregulation of actin alpha 2 (ACTA2), collagen type I alpha 1 (COL1A1), TIMP-1 and fibronectin-1 (FN1) [19, 300]. In the same manner, there was enhanced expression of miR-27a and miR$27 \mathrm{~b}$ in activated HSCs, and their downregulation was responsible for the decreased HSCs proliferation and increased in lipid droplets showing that miR-27a and miR-27b could have a trigger role in HSCs quiescent phenotype [19, 301]. In addition, it was established that miR-27a and miR-27b directly targeted the 3'-untranslated region (3'-UTR) of retinoid X receptor-alpha $(\mathrm{RXR} \alpha)$ to suppress its expression in HSCs reducing DNA synthesis and, consequently, cell proliferation [19, 45, 302].

\section{HSCs in viral hepatitis B and C}

Viral hepatitis $\mathrm{B}(\mathrm{HBV})$ and $\mathrm{C}(\mathrm{HCV})$ are liver diseases that can lead to cirrhosis, liver failure and HCC [303]. They are the most frequent infectious diseases responsible for human liver diseases, including acute, fulminant, and chronic hepatitis [303].

HBV infection is still a crucial worldwide health issue, as it affects more than 350 million people chronically and kills approximately 600000 people every year [304]. In $\mathrm{HBV}$, the proliferation of the healthy population of HSCs is increased by PDGF and TGF- $\beta$ [305-307] and is decreased once they get infected with the extracellular virus [304]. It was reported that hepatitis $B$ virus $X$ protein $(\mathrm{HBx})$ is responsible for the activation of human HSCs by upregulating TGF- $\beta 1$ [307, 308]. Thus, HBx may stimulate hepatic fibrosis by supporting HSCs proliferation and upregulating the expression of fibrosis-associated molecules [271, 307, 308].

It seems that during chronic HBV infection activated Ito cells secrete IL- 6 and IL- $1 \beta$, leading to T-helper 17 (Th17) cells activation [19]. IL-17 generated by the Th17 cells stimulates stellate cells through IL-17 receptor (IL$17 \mathrm{R})$, contributing to upregulation of profibrogenic factors, such as IL-6, TGF- $\beta, \alpha$-SMA and collagen I [309, 310], supporting the fact that IL-17 has a key role in liver fibrosis [19]. In the same manner, IL-22 also is involved in HCV-related fibrosis through the activation of HSCs [19]. Also, IL-22 is responsible for LX-2 cell proliferation, overexpression of $\alpha$-SMA and up-regulation of collagen synthesis by LX-2 cells [311].

A study conducted by Łotowska \& Lebensztejn revealed that HSCs in children with chronic hepatitis B exhibited a tight positive correlation between the cell count and the severity of fibrosis, concluding that they have prognostic roles in this disease [253].

Chronic viral hepatitis $\mathrm{C}$ affects around 3\% of world population [251]. It seems that $\mathrm{C}$ viral proteins regulate apoptosis and steatosis, finally leading to HSCs activation, fibrogenesis and hepatocarcinogenesis [251]. At first, the immune cells try to eliminate the virus, but in the background of chronic infection, perhaps they induce hepatocyte impairment and fibrosis by direct cellular toxicity and by producing inflammatory cytokines [251, $312,313]$. It seems that several patients with chronic hepatitis C will undergo cirrhosis rapidly ("fast fibrosers"), several will develop cirrhosis slowly ("slow fibrosers") and the remainders are named as "intermediate fibrosers" [251]. It is well documented that HSCs have a crucial role in the process of fibrosis and its progress to cirrhosis $[51,314,315]$. In case of stress and injury, like in chronic viral hepatitis C, HSCs become activated and develop myofibroblastic features, producing increased ECM accumulation [251].

$\mathrm{HCV}$ activates HSCs in a direct or indirect way, promoting fibrogenesis [316]. It was reported that E2 protein of $\mathrm{HCV}$ directly binds CD81 existing on the surface of Ito cells [317]. Moreover, the interaction between HCV core proteins, NS3-NS5 and HSCs lead to the initiation of pro-inflammatory cytokines including RANTES, MCP-1, and IL-8 [318]. In addition, double-stranded RNA (dsRNA) could stimulate HSCs activation by TLR3 leading to the secretion of type 1 IFNs (IFN- $\alpha /-\beta$ ) [319]. Also, retinoic acid-inducible gene I (RIG-I), a cytoplasmic detector of viral RNA, was involved in the activation of LX-2 cells (HSCs) generating type 1 IFN (IFN- $\beta$ ) and type III IFN $(\mathrm{IFN}-\gamma)$ [319].

A recent study conducted by Shahin et al. revealed that carboxyl and amino termini of $\mathrm{HCV}$ core protein could activate HSCs [320]. It was shown that HCVinfected hepatocytes can indirectly activate stellate cells through TGF- $\beta 1$ and other profibrogenic factors [321]. HSCs have the property to enclose by phagocytosis apoptotic bodies, released from infected apoptotic 
hepatocytes, which triggers a profibrogenic response $[200$, 322]. In addition, activated Ito cells are responsible for the elaboration of IL- $1 \alpha$, which successively induce $\mathrm{HCV}$-infected hepatocytes, leading to the initiation of proinflammatory cytokines and chemokines like IL-6, IL-8, MIP- $1 \alpha$ and MIP- $1 \beta$ [323]. Furthermore, other reports have revealed indirect activation of stellate cells through ubiquitin carboxy-terminal hydrolase L1 (UCHL1), a new protein generated from $\mathrm{HCV}$-infected hepatocytes involved in the activation of c-Jun N-terminal kinase (JNK) signaling leading to the overexpression of $\alpha$-SMA and later activation of HSCs [324].

It was reported that IL-18, a component of the IL-1 family, supports the proliferation of $\mathrm{HSCs}$, during $\mathrm{HCV}$ infection by modulating the activation of c-Jun levels [325]. It was demonstrated that quantitative assessment of activated HSCs, by immunohistochemistry, could be a helpful marker in prognosticate the development and evolution of liver fibrosis in patients with recurrent hepatitis $\mathrm{C}$ after liver transplantation [28, 326].

Many studies conducted on viral hepatitis [246-250] and livers with severe necrosis [2, 327, 328] revealed the morphology and the IHC profile of stellate cell activation. Using the $\alpha$-SMA IHC marker, several studies revealed that the number of activated HSCs increased, due to the severity of chronic hepatic lesions in $\mathrm{HCV}$-infected patients, pointing to a strong correlation between HSCs activity, liver fibrosis and necroinflammatory activity [250, 327-331]. On the other hand, there are authors who did not find a relationship between activated HSCs and necroinflammatory activity, probably because most HSCs were directly activated by $\mathrm{HCV}$, while necroinflammatory activity only played a secondary role $[250,251,326]$.

\section{$\square$ The role of HSCs in liver tumors}

HCC and intrahepatic cholangiocarcinoma (ICC) are the most frequent forms of primary liver tumors [254]. Furthermore, the liver is the organ most affected by metastasis, after lymph nodes, for the main cancers, including gastrointestinal cancers, breast and prostate carcinomas, uveal melanoma, neuroendocrine tumors, and sarcomas [254, 262, 332-335]. Also, metastases are more frequent than primary liver tumors [254, 336, 337].

The tumor microenvironment (TEM) has a key role in the development of liver tumors [254]. TEM is also known as stroma, and essentially is composed of the ECM and stromal cells [254, 257]. Under physiological conditions, stroma ensures the tissue homeostasis and prevents tumor development; even so, when a cell becomes malignant, its supporting matrix changes in a manner to sustain tumor development [254, 257, 338, 339]. This changed stroma that supports cancerous cells is named TEM [257, 340]. TEM is composed of fibroblasts, MFBs, SECs, Kupffer cells, HSCs, immune and inflammatory cells, and the ECM components [254, 257, 338, 341]. The mutual crosstalk between all these TEM components lead significantly to tumor progression [254]. It seems like HSCs have a crucial role in the TEM crosstalk [254].

Regarding the fact that HSCs stimulate and influence the production of cytokines and growth factors which regulate liver proliferation and regeneration, in several clinical situations, their increased activation led to liver malignancies, like HCC and ICC [254].

\section{a The role of HSCs in HCC}

$\mathrm{HCC}$ is one of the most fatal and common tumors in the human population [254, 256, 257, 336, 342]. HCC represents the main primary liver tumor and the fourth leading cause responsible for cancer deaths in the whole world [254, 336, 342]. It is responsible for $90 \%$ of whole cases of primary hepatic tumors [343]. The main etiology for HCC is chronic infection with HBV or HCV [254, $256,257]$. Other etiological factors are alcohol abuse, autoimmune hepatitis, and NASH [254, 257]. Persistent inflammation from time to time alters the hepatocytes DNA in a regenerating liver, thereby maximizing the occasion of gene modification, leading to carcinogenesis [254]. It is well established that the majority of HCC occurs after a chronic liver injury, and subsequently liver cirrhosis represents the principal risk factor for generating HCC [254, 257].

The evolution of HCC is controlled by the liver microenvironment [254, 256, 257]. Activated HSCs represent the main elements of the HCC microenvironment and have a crucial role in the development and progression of HCC through the production of growth factors, cytokines, ECM and MMPs [153, 254, 256, 257, 262]. Also, they promote tumor neoangiogenesis and immunosuppression [153, 254, 256, 257, 262]. It is well established that activated Ito cells infiltrate the stroma of $\mathrm{HCC}$ and peritumoral tissue and are found around tumor sinusoids, fibrous septa and the tumor capsule $[130,254,256,257$, 344]. In addition, activated HSCs have been found around the periphery of dysplastic nodules within the liver [256, 345]. After activation, HSCs produce increase quantity of ECM proteins into the stroma [256]. The accumulation and degradation of fibrotic matrix by stellate cells is closely modulated in the liver [256]. Thus, TIMP-1 secretion promotes scar accumulation through suppression of endogenous matrix-degrading activities of different MMPs [256]. HSCs generate proteolytic enzymes that influence the ECM turnover, such as tissue inhibitor of metalloproteinase-2 (MMP-2/TIMP-2) and A disintegrin and metalloproteinase domain-containing protein 9 (ADAM-9) [262]. Furthermore, the elevation of TIMPs increases ECM accumulation, which promotes the progression of HCC [254]. Another interesting finding is that the biomechanical features of the ECM also contribute to the evolution of HCC [256]. There are evidences that in vitro increasing matrix stiffness promotes the growth of the HCC cell lines, HuH-7 and HepG2, and decrease the apoptosis related to chemotherapy $[256,346]$. In addition, stromal stiffness is responsible for stellate cell activation, leading to fibrosis [256]. It seems that mechanical tension supported by a modified ECM may promote HCC development and progression by external signals, like integrins, which provide tumor growth and evolution [256].

Integrins mediate the crosstalk between HSCs and HCC cells [256]. Integrins represent a family of transmembrane receptors that 'incorporate' the extracellular and intracellular domains by connecting the ECM and the cytoskeleton [256, 347]. Thus, integrins modulate cell adherence, disseminating, migration, proliferation, and differentiation, even ECM accumulation and remodulation $[256,348]$. It seems that in activated stellate cells down- 
stream integrin signaling, through FAK-phosphatidylinositol 3-kinase (PI3K)-Akt signaling pathway, stimulates ECM accumulation [349]. In vitro studies revealed that the expression and activity of integrins and focal cohesivity are increased by enhanced ECM stiffness, leading to the activation of downstream integrin signals within the hepatocyte, that could favor the development and survival of preneoplastic cells [256]. Evidences have shown that softer matrices abolished hepatoma growth and stiffer matrices favored proliferation, suggesting that matrix stiffness influences differentiation and chemotherapeutic opposition of human HCC cell lines [346, 350]. Another study revealed that HSCs cultured on a stiff medium elicited a higher tumor development compared to HSCs cultured on soft environment [273], supporting the contribution of stiffness in tumor evolution [153].

Studies in human HCC and murine HCC models highlighted connections between collagen expression, integrin expression and tumorigenicity [256, 351, 352]. Analysis of integrin expression in HCC cell lines have shown a high grade of inhomogeneity in integrin expression [353]. A study conducted by Lai et al. using two clinically pertinent mouse models of HCC, PDGF-C overexpression and Pten $-/-$ null mice, established that each model had a characteristic type of integrin gene expression, ultimately showing the heterogeneity of HCC biology [352].

$\beta 1$ Integrin subfamily has been intensively analyzed in HCC; hepatocarcinogenesis is associated with increased expression of integrins $\alpha 1 \beta 1, \alpha 2 \beta 1$ and $\alpha 3 \beta 1$ and the acquirement of a migratory phenotype by hepatocytes [256]. In addition, it was established a positive association between integrin $\beta 1$ expression in human HCC tissues and ECM stiffness, histological tumor grade and metastasis [354]. It seems like the inhibition of integrin $\beta 1$ in vitro importantly abolishes migration and invasion of HCC cell lines elicited by TGF- $\beta 1$ and EGF $[355,356]$. In contrast, enhance of integrin $\beta 1$ has been reported to increase the migration of HepG2 cell [357]. A study conducted by Dong et al. using a strong-stiffness gel to culture HCC cell lines, discovered that VEGF expression is inhibited by treatment with an integrin $\beta 1$-specific antibody [350]. Other integrin subunits have been found to have a major contribution in the evolution of HCC [256]. For example, Fan et al. have demonstrated that integrin $\alpha 6$ expression is strongly associated with $\mathrm{HCC}$ in humans [358]. It has been reported that superexpressed integrin $\alpha 6$ can form a complex with CD151, a tetraspanin protein, which promotes HCC invasion, and the PI3K-Akt signaling pathway, leading to increased epithelial-to-mesenchymal (EMT) of HCC cell lines [358]. Furthermore, evidences have shown that the suppression of integrin $\alpha 3$ on HCC cells abolished the anti-apoptotic role of laminin-332 [359]. Also, the expression of neuropilin-1 by HSCs-derived MFBs supported the production of fibronectin, promoting the TEM stiffness and leading to increased tumor growth [360].

It seems like the crosstalk between integrins and TGF- $\beta$ signaling is also involved in hepatocarcinogenesis [256]. It has been shown that the HCC cell invasiveness was stimulated by the activation of TGF- $\beta$ receptor inhibitor (RI) through phosphorylation of the intracellular component of the $\beta 1$ subunit of the integrin $\alpha 5 \beta 1$ by Smad- 2 and Smad-3, leading to an inside-out conformational modification and promoting vascular invasion [361]. Moreover, the interconnection between integrins, growth factor receptors and ECM proteins like collagen, have demonstrated to modify downstream signal activity pathways like Smad, favoring hepatocyte proliferation and preserving HSCs activation $[362,363]$.

Activated HSCs promote tumor cell proliferation, migration, and invasion by production of a wide range of growth factors and cytokines, including TGF- $\beta$, HGF, PDGF, SDF-1, VEGF, and CXCL12 [273, 360, 364-367], and by downregulating other molecules like endosialin [368]. It seems that tumor cell invasion and proliferation were stimulated by conditioned media of activated stellate cells in vitro [153, 364, 365] and in vivo [153, 273]. Furthermore, it was observed that co-incorporating stellate cells with HCC cells into the nude mice amplified the tumor development and invasiveness by activating NF- $\kappa \mathrm{B}$ and extracellular signal-regulated kinase (ERK) signaling pathways [257, 365, 369]. Moreover, microarray examinations have shown the activation of some genes of inflammation, MMPs, chemotaxis and angiogenesis, succeeding the co-implantation of hepatic tumoral cells with activated stellate cells [370].

Studies using a co-transplant model of HCC cells and HSCs revealed that TGF- $\beta$ signaling intrusion diminished the growth of HCC in vivo [254]. Also, TGF- $\beta$ was regularly secreted in an autocrine fashion by HCC cells [371-373]. It was reported that HSCs stimulated EMT in HCC cells by TGF- $\beta$ [374]. Thus, TGF- $\beta$ plays a key role in the interaction between HCC cells and stellate cells [254].

It seems that the downregulation of the expression levels of TGF- $\beta$ receptors in HCC compared with those in the neighboring normal tissues demonstrated the significance of TGF- $\beta$ signaling in the induction of HCC [375]. Moreover, this downregulation was responsible for an increase tumor growth and a higher proliferation ability [375]. It was reported that the gene expression changes were also detected in co-Smad subunits [257]. For example, in HCC tissues the expression of Smad-4 was amplified and its small interfering RNA (siRNA)mediated inhibition, suppressed the colony development in Huh7 and PLC cell lines [376]. Hepatic tumor-initiating cells could be originated from hepatic progenitor cells, chronic stimulated by TGF- $\beta$ in cirrhotic liver [377]. It was shown that hypoxic hepatocytes produce enzymes that activate dormant TGF- $\beta$; hypoxia stimulates EMT in hepatocytes in a TGF- $\beta$-dependent way [377].

TGF- $\beta$ stimulates the growth of a TEM by producing cancer-associated fibroblasts (CAFs), which generate growth factors and cytokines [378-380]. Furthermore, TGF- $\beta$ activates HSCs into MFBs [254].

Another growth factor secreted by stellate cells and involved in tumor cell invasion and metastasis is HGF [256]. It is known that HGF controls cell proliferation, migration, survival and angiogenesis [256, 381, 382]. It seems that HGF fixes to its receptor, c-MET, leading to a phosphorylation cascade [256]. It was shown that 20 $48 \%$ of HCCs contain a transmembrane receptor tyrosine kinase, c-MET, which is expressed by numerous HCC 
cell lines [365]. Several studies highlighted associations between enhanced c-MET and tumor size or invasiveness of HCC [383, 384]. In addition, c-MET-regulated expression signature of HCC cells has been associated with a poor prognosis, reduced 5-year survival and an aggressive phenotype of HCC $[385,386]$. Also, activation of HGF/ c-MET signaling has been proven to increase HCC chemoresistance [256].

It was shown that conditioned media collected from the activated HSCs cell line LX-2 increased resistance of the HCC cell line Hep3B to the chemotherapeutic agent Cisplatin, reaction regulated via HGF [387]. Neoplastic cells could also amplify prometastatic c-MET signaling through an autocrine pathway including TIMP-1, leading to downstream expression of metastasis-promoting genes [388, 389].

Evidence have shown that LPS and the gut microbiome also promote hepatocarcinogenesis [153, 256]. It was observed that LPS and the gut microbiome can initiate HSCs activation, leading to the secretion of the mitotic factors HGF and epiregulin, which probably act on tumoral hepatocytes [256]. It is known that epiregulin represents a component of the EGF family and leads to the activation of EGF receptor and human epidermal growth factor receptor 2 (HER2) during initial phases of Diethylnitrosamine (DEN)/ $\mathrm{CCl}_{4}$ carcinogenesis, whereas it decreases hepatocyte apoptosis via NF- $\kappa \mathrm{B}$ nuclear translocation during advanced phases [390, 391].

Another crucial role of HSCs in HCC growth, evolution, and metastasis is the induction of angiogenesis [254, 256, $257,262]$. In order to develop, neoplastic hepatocytes need new vessel generation, initiated by numerous proangiogenic factors [256]. It seems that these pro-angiogenic factors promote tumor evolution and metastasis [256].

It is well known that activated stellate cells generate numerous angiogenic factors, such as VEGF, PDGF, MMPs, FGF, TGF- $\beta 1$, EGF, angiopoietin-1 (Ang-1) and Ang-2 [392-394]. Moreover, Ito cells exhibit angiogenic growth factor receptors, like VEGFR, PDGFR and Tie2 [256]. In hepatic insult and HCC, this simplifies mutual signaling between stellate cells and endothelial cells or tumoral hepatocytes and favors a pro-angiogenic microenvironment. It was observed that during the coimplantation of HSCs with HCC cells, HCC cells increase the expression of pro-angiogenic genes ( VEGF- $A$ and $M M P-2)$ in HSCs, as well as their proliferation and migration [395].

In vitro studies have reported that VEGF enhances endothelial cells migration, stimulates their proliferation, and diminishes apoptosis, all phases being mandatory for new vessel development [262]. Furthermore, mutually in vitro and in vivo researches have reported that the secretion of VEGF is stimulated by hypoxic situations, a usual feature of the TEM [262]. Also, it seems like activated stellate cells initiate vascular tube development by liver SECs and vascular endothelial cells. In addition, they intensely accumulated matrix laminin, which favors both tumor survival and evolution through EMT, and is also involved in synthesis of the basement membrane the for the new vessels [262].

A research conducted by Lin et al. using a murine HCC cell line and rat colon microvascular endothelial cells, observed amplified angiogenesis by activated HSCs in vitro [396]. Lin et al. also revealed, by utilizing an orthotopic HCC model, that activated HSCs stimulate tumor angiogenesis by enhanced VEGF and probably PDGF production [396]. An interesting finding in HCC is the crosstalk between tumoral hepatocytes, endothelial cells and activated HSCs. It has been described the increased expression of Ang-1, Ang-2 and Tie2 receptors in cultured HCC cell lines (HLE and $\mathrm{HuH}-7$ ) and in human HCC specimens [397]. This study established that angiopoietin-Tie 2 signaling in the vascular wall could promote vessel remodeling in HCC [396].

Ang-2 produced by HCC cells, Ito cells and smooth muscle cells fixes Tie2 receptor (expressed on HSCs, smooth muscle, and endothelial cells) and alters the contacts between endothelial cells, perivascular support cells and ECM [256]. This supports the contact with VEGF, which in these fairly hypoxic circumstances, is upregulated. All these events lead to endothelial cells proliferation, neovascularization, and tumor progression [256].

It was reported that Metformin suppresses angiogenesis in vitro, in an HCC (HepG2 line) and HSCs (LX-2) co-culture environment [398]. Tumor immune escape mechanism plays a key role in cancer evolution [256]. One path by which tumors escape the immune reaction is via the increase number and activity of immunosuppressive cells in the tumor and within lymphoid organs [399]. Such immunosuppressive cells comprise of Tregs and myeloid-derived suppressor cells (MDSCs). There are a wide range of studies that show the immunomodulatory roles of HSCs, which could encourage the existence, growth, and evolution of $\mathrm{HCC}$ in vitro and in vivo $[400,401]$.

It was demonstrated that activated stellate cells increase immunosuppressive cell populations in the HCC microenvironment by stimulating T-cell apoptosis and modifying the equilibrium of diverse T-cell populations [256]. Also, a close association between the intratumoral number of HSCs, T-cell apoptosis and lung metastatic nodules was observed in an orthotopic rat model of HCC [402]. This finding highlights the role of HSCs in HCC metastasis through an immunosuppressive way.

It was reported that co-implantation of $\mathrm{HCC}$ cells with HSCs in immunocompetent mice stimulated HCC proliferation and increased tumor angiogenesis, in correlation with suppression of lymphocyte infiltration and apoptosis of infiltrating monocytes [256].

A study conducted by Zhao et al. revealed, in an orthotopic liver tumor mouse model, that HSCs have an immunosuppressive function for HCC via initiation of Tregs and MDSCs, perhaps due to activation of cyclooxygenase-2 (COX2)-PGE2-EP4 signaling pathway [403]. Furthermore, it seems that activated HSCs suppress antitumor cytotoxic T-cells, therefore defending the hepatic tumor. Tumor-related HSCs stimulate DC-derived immunoglobulin receptor 2 (DIgR2) in DCs, which ultimately suppress the inflammatory reply of T-cells [404].

In a different perspective, it is believed that tumoral hepatocytes and activated stellate cells create, together with CAFs and immune cells, a tumor-related environment in which the receptiveness of tumor cells to soluble factors 
is augmented [380]. Thus, activated HSCs represent the hallmarks in tumor cell milieu creation that determines the malignancy and prognostic of the tumor event.

\section{a Behavior of HSCs in ICC}

ICC is the next most frequent form of primary liver cancers, representing $5 \%$ of primary liver tumors [254]. It represents a destructive type of malignancy and has a worse prognosis, as therapeutic schemes against ICC are restrained [254]. Chemotherapy and radiotherapy are partially successful as ICC shows a fibrous stroma that is opposing to these treatments [254].

There are fewer reports concerning the role of TEM in ICC compared with those involving the HCC tumor milieu [254]. It seems that the desmoplastic stroma adjacent to ICC cells play a key role for the growth of ICC [254].

TEM composed of HSCs, SECs, CAFs, Kupffer cells and tumor-infiltrating lymphocytes (TILs) is responsible for the development, evolution, metastasis, and invasion of ICC. These cells promote the tumor development by producing many soluble factors [254]. It seems like these factors increase ICC cell multiplication and migration and also encourage the abnormal activation of other stromal cells $[405,406]$. A study conducted by Sulpice et al. revealed that the stroma of ICC contains upregulated genes associated with the cell cycle, ECM and TGF- $\beta$. In addition, it was proved that the ICC prognosis is strongly associated with the stromal expression of osteopontin (OPN) [405]. It is known that osteopontin is involved in HSCs activation via TGF- $\beta$ 1. Thus, activated HSCs may contribute to ICC evolution via OPN [406].

HSCs produce SDF-1, which controls ICC cell migration and survival [407]. Furthermore, SDF-1 increases the EMT via the crosstalk between activated HSCs and the SDF-1/ CXCR4 axis in ICC [408]. Also, HSCs are activated by SDF-1 in an autocrine way. It seems that in ICC, elevated expression of ECM was related with a worse prognosis [254]. One of the main ECM components in ICC is represented by HSCs. It was shown that ICC tumors displayed an elevated expression of $\alpha$-SMA, a marker of HSCs, as well as significantly poor survival, in contrast to low- $\alpha$-SMA-expression tumors [364, 409]. The proliferation and invasion of ICC cells were enhanced by co-implanting an ICC cell line with an HSCs line [364].

A study conducted by Kim et al. established that HSCs promote the proliferation, migration, angiogenesis, and invasion of ICC cells, induce angiogenesis by Hh signaling pathway activation, and makes ICC more vulnerable to necrosis by Hh pathway inhibitors [410]. All this evidence shows the key role of HSCs in the progression of ICC.

\section{a Conclusions}

From past till nowadays, many findings have been made regarding these "pluripotent cells" and no one could have imagined their complex capacity when they were first discovered. HSCs represent the remarkable cells of the liver due to their ability to preserve hepatic homeostasis, development, and regeneration as well as their crucial roles in the pathogenesis of liver diseases. All of these fundamental characteristics make the HSCs a powerful therapeutic target for liver pathology. By isolating diverse HSCs subpopulations and particularly targeting the highly fibrogenic types, researchers aim to create new therapies in liver diseases. Some promising anti-fibrotic approaches aspiring the inhibition or reversal of HSCs stimulated liver fibrosis have been created [411]. In addition, Cenicriviroc, a double $\mathrm{C}-\mathrm{C}$ chemokine receptor type 2 and 5 (CCR2/ CCR5) antagonist, was used in phase 2 clinical trial and has been assessed in liver inflammation and fibrosis in the setting of NASH [412]. Furthermore, activated HSCs represent a main component of the TEM. Thus, they could be an important therapeutic target for hepatic tumors. For example, human monoclonal antibodies against FAP, Sibrotuzumab and Val-boroPro could be applied for targeting activated stellate cells [413, 414]. Another therapeutic strategy could be Hh signaling pathway [415]. Suppressing the Hh signaling pathway may inhibit the activation of HSCs. As our knowledge regarding HSCs and their essential involvement in liver homeostasis and pathology increases, the cure of hepatic diseases will become promising.

\section{Conflict of interests}

The authors declare that they have no conflict of interests.

\section{References}

[1] ${ }^{* * *}$. Hepatic stellate cell nomenclature. Hepatology, 1996, 23(1):193. PMID: 8550043

[2] Friedman SL. Hepatic stellate cells: protean, multifunctional, and enigmatic cells of the liver. Physiol Rev, 2008, 88(1): 125-172. https://doi.org/10.1152/physrev.00013.2007 PMID: 18195085 PMCID: PMC2888531

[3] Senoo H. Structure and function of hepatic stellate cells. Med Electron Microsc, 2004, 37(1):3-15. https://doi.org/10.1007/ s00795-003-0230-3 PMID: 15057600

[4] Wake K. "Sternzellen" in the liver: perisinusoidal cells with special reference to storage of vitamin A. Am J Anat, 1971, 132(4):429-462. https://doi.org/10.1002/aja.1001320404 PMID: 4942297

[5] Wake K. Perisinusoidal stellate cells (fat-storing cells, interstitial cells, lipocytes), their related structure in and around the liver sinusoids, and vitamin A-storing cells in extrahepatic organs. Int Rev Cytol, 1980, 66:303-353. https://doi.org/10.1016/s00 74-7696(08)61977-4 PMID: 6993411

[6] Ito T. Cytological studies on stellate cells of Kupffer and fat storing cells in the capillary wall of human liver (abstract). Acta Anat Jpn, 1951, 26:42.

[7] Bronfenmajer S, Schaffner F, Popper $\mathrm{H}$. Fat-storing cells (lipocytes) in human liver. Arch Pathol, 1966, 82(5):447-453. PMID: 5923468

[8] Kent G, Gay S, Inouye T, Bahu R, Minick OT, Popper H. Vitamin A-containing lipocytes and formation of type III collagen in liver injury. Proc Natl Acad Sci U S A, 1976, 73(10):3719-3722. https://doi.org/10.1073/pnas.73.10.3719 PMID: 1068482 PMCID: PMC431190

[9] Gutiérrez-Ruiz MC, Gómez-Quiroz LE. Liver fibrosis: searching for cell model answers. Liver Int, 2007, 27(4):434-439. https:// doi.org/10.1111/j.1478-3231.2007.01469.x PMID: 17403182

[10] Martinez-Hernandez A. The hepatic extracellular matrix. I. Electron immunohistochemical studies in normal rat liver. Lab Invest, 1984, 51(1):57-74. PMID: 6376944

[11] Friedman SL, Roll FJ. Isolation and culture of hepatic lipocytes, Kupffer cells, and sinusoidal endothelial cells by density gradient centrifugation with Stractan. Anal Biochem, 1987, 161(1):207-218. https://doi.org/10.1016/0003-2697(87)9067 3-7 PMID: 3578783

[12] Chen W, Gendrault JL, Steffan AM, Jeandidier E, A. Kirn A. Isolation, culture and main characteristics of mouse fat-storing cells: interaction with viruses. Hepatology, 1989, 9(3):352-362. https://doi.org/10.1002/hep.1840090303 PMID: 2465986 
[13] Friedman SL, Rockey DC, McGuire RF, Maher JJ, Boyles JK Yamasaki G. Isolated hepatic lipocytes and Kupffer cells from normal human liver: morphological and functional characteristics in primary culture. Hepatology, 1992, 15(2):234-243. https://doi.org/10.1002/hep.1840150211 PMID: 1735526

[14] Zhai X, Wang W, Dou D, Ma Y, Gang D, Jiang Z, Shi B, Jin B. A novel technique to prepare a single cell suspension of isolated quiescent human hepatic stellate cells. Sci Rep, 2019, 9(1):12757. https://doi.org/10.1038/s41598-019-49287-7 PMID: 31485000 PMCID: PMC6726602

[15] Galler K, Requardt RP, Glaser U, Markwart R, Bocklitz T, Bauer M, Popp J, Neugebauer U. Single cell analysis in native tissue: quantification of the retinoid content of hepatic stellate cells. Sci Rep, 2016, 6:24155. https://doi.org/10.1038/srep 24155 PMID: 27063397 PMCID: PMC4827054

[16] Testerink N, Ajat M, Houweling M, Brouwers JF, Pully VV, van Manen HJ, Otto C, Helms JB, Vaandrager AB. Replacement of retinyl esters by polyunsaturated triacylglycerol species in lipid droplets of hepatic stellate cells during activation. PLoS One, 2012, 7(4):e34945. https://doi.org/10.1371/journal.pone. 0034945 PMID: 22536341 PMCID: PMC3335019

[17] Weiskirchen R, Tacke F. Cellular and molecular functions of hepatic stellate cells in inflammatory responses and liver immunology. Hepatobiliary Surg Nutr, 2014, 3(6):344-363. https://doi.org/10.3978/j.issn.2304-3881.2014.11.03 PMID: 25568859 PMCID: PMC4273119

[18] Giampieri MP, Jezequel AM, Orlandi F. The lipocytes in normal human liver. A quantitative study. Digestion, 1981, 22(4):165169. https://doi.org/10.1159/000198640 PMID: 7308589

[19] Gupta G, Khadem F, Uzonna JE. Role of hepatic stellate cell (HSC)-derived cytokines in hepatic inflammation and immunity. Cytokine, 2019, 124:154542. https://doi.org/10.1016/j.cyto. 2018.09.004 PMID: 30241896

[20] Gressner AM, Weiskirchen R. Modern pathogenetic concepts of liver fibrosis suggest stellate cells and TGF-beta as major players and therapeutic targets. J Cell Mol Med, 2006, 10(1): 76-99. https://doi.org/10.1111/j.1582-4934.2006.tb00292.x PMID: 16563223 PMCID: PMC3933103

[21] Vassy J, Rigaut JP, Briane D, Kraemer M. Confocal microscopy immunofluorescence localization of desmin and other intermediate filament proteins in fetal rat livers. Hepatology, 1993, 17(2):293-300. https://doi.org/10.1002/hep.1840170221 PMID 7679087

[22] Suskind DL, Muench MO. Searching for common stem cells of the hepatic and hematopoietic systems in the human fetal liver: CD34+ cytokeratin 7/8+ cells express markers for stellate cells. J Hepatol, 2004, 40(2):261-268. https://doi.org/ 10.1016/j.jhep.2003.11.007 PMID: 14739097

[23] Kalinichenko VV, Bhattacharyya D, Zhou Y, Gusarova GA Kim W, Shin B, Costa RH. Foxf1 +/- mice exhibit defective stellate cell activation and abnormal liver regeneration following $\mathrm{CCl}_{4}$ injury. Hepatology, 2003, 37(1):107-117. https://doi.org/ 10.1053/jhep.2003.50005 PMID: 12500195

[24] Asahina K, Zhou B, Pu WT, Tsukamoto H. Septum transversumderived mesothelium gives rise to hepatic stellate cells and perivascular mesenchymal cells in developing mouse liver. Hepatology, 2011, 53(3):983-995. https://doi.org/10.1002/ hep.24119 PMID: 21294146 PMCID: PMC3078645

[25] Geerts A. History, heterogeneity, developmental biology, and functions of quiescent hepatic stellate cells. Semin Liver Dis, 2001, 21(3):311-335. https://doi.org/10.1055/s-2001-17550 PMID: 11586463

[26] Geerts A. On the origin of stellate cells: mesodermal, endodermal or neuro-ectodermal? J Hepatol, 2004, 40(2):331-334 https://doi.org/10.1016/j.jhep.2003.12.006 PMID: 14739107

[27] Kendall TJ, Hennedige S, Aucott RL, Hartland SN, Vernon MA Benyon RC, Iredale JP. p75 Neurotrophin receptor signaling regulates hepatic myofibroblast proliferation and apoptosis in recovery from rodent liver fibrosis. Hepatology, 2009, 49(3): 901-910. https://doi.org/10.1002/hep.22701 PMID: 19072833

[28] Moreira RK. Hepatic stellate cells and liver fibrosis. Arch Pathol Lab Med, 2007, 131(11):1728-1734. https://doi.org/ 10.1043/1543-2165(2007)131[1728:HSCALF]2.0.CO;2 PMID: 17979495

[29] Friedman SL, Roll FJ, Boyles J, Bissell DM. Hepatic lipocytes: the principal collagen-producing cells of normal rat liver. Proc Natl Acad Sci U S A, 1985, 82(24):8681-8685. https://doi.org/ 10.1073/pnas.82.24.8681 PMID: 3909149 PMCID: PMC391500
[30] Blaner WS, O'Byrne SM, Wongsiriroj N, Kluwe J, D'Ambrosio DM, Jiang $\mathrm{H}$, Schwabe RF, Hillman EM, Piantedosi R, Libien J. Hepatic stellate cell lipid droplets: a specialized lipid droplet for retinoid storage. Biochim Biophys Acta, 2009, 1791(6): 467-473. https://doi.org/10.1016/j.bbalip.2008.11.001 PMID: 19071229 PMCID: PMC2719539

[31] Senoo H, Kojima N, Sato NM. Vitamin A-storing cells (stellate cells). Vitam Horm, 2007, 75:131-159. https://doi.org/10.10 16/S0083-6729(06)75006-3 PMID: 17368315

[32] Senoo H, Sato M, Imai K. Hepatic stellate cells - from the viewpoint of retinoid handling and function of the extracellular matrix. Kaibogaku Zasshi, 1997, 72(2):79-94. PMID: 9153961

[33] Zou Z, Ekataksin W, Wake K. Zonal and regional differences identified from precision mapping of vitamin A-storing lipid droplets of the hepatic stellate cells in pig liver: a novel concept of addressing the intralobular area of heterogeneity. Hepatology, 1998, 27(4):1098-1108. https://doi.org/10.1002/ hep.510270427 PMID: 9537451

[34] Wake K, Sato T. Intralobular heterogeneity of perisinusoidal stellate cells in porcine liver. Cell Tissue Res, 1993, 273(2): 227-237. https://doi.org/10.1007/BF00312824 PMID: 7689937

[35] Wake K. Development of vitamin A-rich lipid droplets in multivesicular bodies of rat liver stellate cells. J Cell Biol, 1974, 63(2 Pt 1):683-691. https://doi.org/10.1083/jcb.63.2.683 PMID: 4421899 PMCID: PMC2110931

[36] Yamamoto K, Ogawa K. Fine structure and cytochemistry of lysosomes in the Ito cells of the rat liver. Cell Tissue Res, 1983, 233(1):45-57. https://doi.org/10.1007/BF00222231 PMID: 6616565

[37] Geerts A, Bouwens L, Wisse E. Ultrastructure and function of hepatic fat-storing and pit cells. J Electron Microsc Tech, 1990, 14(3):247-256. https://doi.org/10.1002/jemt.1060140 306 PMID: 2187064

[38] Grigoraş A, Giuşcă SE, Avădănei ER, Amălinei C, Căruntu ID. Pointing at Ito cell, from structure to function (... or Cinderella story in liver histology). Rom J Morphol Embryol, 2016, 57(3): 915-923. PMID: 28002505

[39] Wake K. Cell-cell organization and functions of 'sinusoids' in liver microcirculation system. J Electron Microsc (Tokyo), 1999, 48(2):89-98. https://doi.org/10.1093/oxfordjournals.jmicro. a023666 PMID: 10356785

[40] Melton AC, Yee HF. Hepatic stellate cell protrusions couple platelet-derived growth factor-BB to chemotaxis. Hepatology, 2007, 45(6):1446-1453. https://doi.org/10.1002/hep.21606 PMID: 17465006

[41] Bioulac-Sage P, Lafon ME, Saric J, Balabaud C. Nerves and perisinusoidal cells in human liver. J Hepatol, 1990, 10(1):105112. https://doi.org/10.1016/0168-8278(90)90080-b PMID: 2407769

[42] Tsuchida T, Friedman SL. Mechanisms of hepatic stellate cell activation. Nat Rev Gastroenterol Hepatol, 2017, 14(7):397411. https://doi.org/10.1038/nrgastro.2017.38 PMID: 28487545

[43] Khomich O, Ivanov AV, Bartosch B. Metabolic hallmarks of hepatic stellate cells in liver fibrosis. Cells, 2019, 9(1):24. https://doi.org/10.3390/cells9010024 PMID: 31861818 PMCID: PMC7016711

[44] Ueno T, Sata M, Sakata R, Torimura T, Sakamoto M, Sugawara H, Tanikawa K. Hepatic stellate cells and intralobular innervation in human liver cirrhosis. Hum Pathol, 1997, 28(8):953-959. https://doi.org/10.1016/s0046-8177(97)90011-3 PMID: 9269832

[45] Puche JE, Saiman Y, Friedman SL. Hepatic stellate cells and liver fibrosis. Compr Physiol, 2013, 3(4):1473-1492. https:// doi.org/10.1002/cphy.c120035 PMID: 24265236

[46] Shang L, Hosseini M, Liu X, Kisseleva T, Brenner DA. Human hepatic stellate cell isolation and characterization. J Gastroenterol, 2018, 53(1):6-17. https://doi.org/10.1007/s00535-0 17-1404-4 PMID: 29094206

[47] Yokoi Y, Namihisa T, Kuroda H, Komatsu I, Miyazaki A, Watanabe S, Usui K. Immunocytochemical detection of desmin in fat-storing cells (Ito cells). Hepatology, 1984, 4(4):709-714. https://doi.org/10.1002/hep.1840040425 PMID: 6204917

[48] Nouchi T, Tanaka Y, Tsukada T, Sato C, Marumo F. Appearance of alpha-smooth-muscle-actin-positive cells in hepatic fibrosis. Liver, 1991, 11(2):100-105. https://doi.org/10.1111/j.1600-06 76.1991.tb00499.x PMID: 2051901 
[49] Schmitt-Gräff A, Krüger S, Bochard F, Gabbiani G, Denk H. Modulation of alpha smooth muscle actin and desmin expression in perisinusoidal cells of normal and diseased human livers. Am J Pathol, 1991, 138(5):1233-1242. PMID: 2024709 PMCID: PMC1886014

[50] Win KM, Charlotte F, Mallat A, Cherqui D, Martin N, Mavier P, Preaux AM, Dhumeaux D, Rosenbaum J. Mitogenic effect of transforming growth factor-beta 1 on human lto cells in culture: evidence for mediation by endogenous platelet-derived growth factor. Hepatology, 1993, 18(1):137-145. PMID: 8325605

[51] Cassiman D, Libbrecht L, Desmet V, Denef C, Roskams T. Hepatic stellate cell/myofibroblast subpopulations in fibrotic human and rat livers. J Hepatol, 2002, 36(2):200-209. https:// doi.org/10.1016/s0168-8278(01)00260-4 PMID: 11830331

[52] Ramm GA, Britton RS, O'Neill R, Blaner WS, Bacon BR. Vitamin A-poor lipocytes: a novel desmin-negative lipocyte subpopulation, which can be activated to myofibroblasts. Am J Physiol, 1995, 269(4 Pt 1):G532-G541. https://doi.org/10.11 52/ajpgi.1995.269.4.G532 PMID: 7485505

[53] Nitou M, Ishikawa K, Shiojiri N. Immunohistochemical analysis of development of desmin-positive hepatic stellate cells in mouse liver. J Anat, 2000, 197(Pt 4):635-646. https://doi.org/ 10.1046/j.1469-7580.2000.19740635.x PMID: 11197537 PMCID: PMC1468179

[54] Skalli O, Ropraz P, Trzeciak A, Benzonana G, Gillessen D, Gabbiani G. A monoclonal antibody against alpha-smooth muscle actin: a new probe for smooth muscle differentiation. J Cell Biol, 1986, 103(6Pt 2):2787-2796. https://doi.org/10. 1083/jcb.103.6.2787 PMID: 3539945 PMCID: PMC2114627

[55] Levy MT, McCaughan GW, Abbott CA, Park JE, Cunningham AM Müller E, Rettig WJ, Gorrell MD. Fibroblast activation protein: a cell surface dipeptidyl peptidase and gelatinase expressed by stellate cells at the tissue remodelling interface in human cirrhosis. Hepatology, 1999, 29(6):1768-1778. https://doi.org/ 10.1002/hep.510290631 PMID: 10347120

[56] Yamaoka K, Nouchi T, Marumo F, Sato C. Alpha-smoothmuscle actin expression in normal and fibrotic human livers. Dig Dis Sci, 1993, 38(8):1473-1479. https://doi.org/10.1007/ BF01308606 PMID: 8344103

[57] Enzan H, Himeno $H$, Iwamura S, Saibara T, Onishi S, Yamamoto $\mathrm{Y}$, Hara $\mathrm{H}$. Immunohistochemical identification of Ito cells and their myofibroblastic transformation in adult human liver. Virchows Arch, 1994, 424(3):249-256. https:// doi.org/10.1007/BF00194608 PMID: 8186890

[58] Nagatsuma K, Hayashi $Y$, Hano H, Sagara H, Murakami K, Saito M, Masaki T, Lu T, Tanaka M, Enzan H, Aizawa Y, Tajiri $\mathrm{H}$, Matsuura $\mathrm{T}$. Lecithin: retinol acyltransferase protein is distributed in both hepatic stellate cells and endothelial cells of normal rodent and human liver. Liver Int, 2009, 29(1):4754. https://doi.org/10.1111/j.1478-3231.2008.01773.x PMID: 18544127

[59] Lepreux S, Dubuisson L, Le Bail B, Desmoulière A, Balabaud C, Bioulac-Sage P. Can hepatic stellate cells express alphasmooth muscle actin in normal human liver? Liver, 2001 21(4):293-294. https://doi.org/10.1034/j.1600-0676.2001.02 1004293.x PMID: 11454194

[60] Blazejewski S, Preaux AM, Mallat A, Brocheriou I, Mavier P Dhumeaux D, Hartmann D, Schuppan D, Rosenbaum J. Human myofibroblastlike cells obtained by outgrowth are representative of the fibrogenic cells in the liver. Hepatology, 1995, 22(3):788-797. PMID: 7657284

[61] Van Rossen E, Vander Borght S, van Grunsven LA, Reynaert H Bruggeman V, Blomhoff R, Roskams T, Geerts A. Vinculin and cellular retinol-binding protein-1 are markers for quiescent and activated hepatic stellate cells in formalin-fixed paraffin embedded human liver. Histochem Cell Biol, 2009, 131(3): 313-325. https://doi.org/10.1007/s00418-008-0544-2 PMID: 19052772

[62] Motoyama H, Komiya T, Thuy le TT, Tamori A, Enomoto M, Morikawa H, Iwai S, Uchida-Kobayashi S, Fujii H, Hagihara A Kawamura E, Murakami Y, Yoshizato K, Kawada N. Cytoglobin is expressed in hepatic stellate cells, but not in myofibroblasts, in normal and fibrotic human liver. Lab Invest, 2014, 94(2): 192-207. https://doi.org/10.1038/labinvest.2013.135 PMID: 24296877

[63] Cassiman D, Denef C, Desmet VJ, Roskams T. Human and rat hepatic stellate cells express neurotrophins and neurotrophin receptors. Hepatology, 2001, 33(1):148-158. https:// doi.org/10.1053/jhep.2001.20793 PMID: 11124831
[64] Bai X, Saab AS, Huang W, Hoberg IK, Kirchhoff F, Scheller A. Genetic background affects human glial fibrillary acidic protein promoter activity. PLoS One, 2013, 8(6):e66873. https://doi. org/10.1371/journal.pone.0066873 PMID: 23826164 PMCID: PMC3691242

[65] Hassan S, Syed S, Kehar SI. Glial fibrillary acidic protein (GFAP) as a mesenchymal marker of early hepatic stellate cells activation in liver fibrosis in chronic hepatitis $C$ infection. Pak J Med Sci, 2014, 30(5):1027-1032. https://doi.org/10. 12669/pjms.305.5534 PMID: 25225520 PMCID: PMC4163226

[66] Carotti S, Morini S, Corradini SG, Burza MA, Molinaro A, Carpino G, Merli M, De Santis A, Muda AO, Rossi M, Attili AF, Gaudio E. Glial fibrillary acidic protein as an early marker of hepatic stellate cell activation in chronic and posttransplant recurrent hepatitis C. Liver Transpl, 2008, 14(6):806-814. https://doi.org/10.1002/It.21436 PMID: 18508359

[67] Niki T, Pekny M, Hellemans K, Bleser PD, Berg KV, Vaeyens F, Quartier E, Schuit F, Geerts A. Class VI intermediate filament protein nestin is induced during activation of rat hepatic stellate cells. Hepatology, 1999, 29(2):520-527. https://doi.org/10.10 02/hep.510290232 PMID: 9918930

[68] Neubauer K, Knittel T, Aurisch S, Fellmer P, Ramadori G. Glial fibrillary acidic protein - a cell type specific marker for Ito cells in vivo and in vitro. J Hepatol, 1996, 24(6):719730. https://doi.org/10.1016/s0168-8278(96)80269-8 PMID: 8835748

[69] Trim N, Morgan S, Evans M, Issa R, Fine D, Afford S, Wilkins B, Iredale J. Hepatic stellate cells express the low affinity nerve growth factor receptor $\mathrm{p} 75$ and undergo apoptosis in response to nerve growth factor stimulation. Am J Pathol, 2000, 156(4): 1235-1243. https://doi.org/10.1016/S0002-9440(10)64994-2 PMID: 10751349 PMCID: PMC1876895

[70] Cassiman D, Roskams T. Beauty is in the eye of the beholder: emerging concepts and pitfalls in hepatic stellate cell research. $\mathrm{J}$ Hepatol, 2002, 37(4):527-535. https://doi.org/10.1016/s01 68-8278(02)00263-5 PMID: 12217608

[71] Evans GJO, Cousin MA. Tyrosine phosphorylation of synaptophysin in synaptic vesicle recycling. Biochem Soc Trans, 2005, 33(Pt 6):1350-1353. https://doi.org/10.1042/BST20051350 PMID: 16246116 PMCID: PMC2077014

[72] Cassiman D, van Pelt J, De Vos R, Van Lommel F, Desmet V, Yap SH, Roskams T. Synaptophysin: a novel marker for human and rat hepatic stellate cells. Am J Pathol, 1999, 155(6):18311839. https://doi.org/10.1016/S0002-9440(10)65501-0 PMID: 10595912 PMCID: PMC1866940

[73] Elrick LJ, Leel V, Blaylock MG, Duncan L, Drever MR, Strachan G, Charlton KA, Koruth M, Porter AJ, Wright MC. Generation of a monoclonal human single chain antibody fragment to hepatic stellate cells - a potential mechanism for targeting liver anti-fibrotic therapeutics. J Hepatol, 2005, 42(6): 888-896. https://doi.org/10.1016/j.jhep.2005.01.028 PMID: 15885360

[74] Kawada N, Kristensen DB, Asahina K, Nakatani K, Minamiyama Y, Seki S, Yoshizato K. Characterization of a stellate cell activation-associated protein (STAP) with peroxidase activity found in rat hepatic stellate cells. J Biol Chem, 2001, 276(27):25318-25323. https://doi.org/10.1074/jbc.M102630 200 PMID: 11320098

[75] Yoshizato K, Thuy LTT, Shiota G, Kawada N. Discovery of cytoglobin and its roles in physiology and pathology of hepatic stellate cells. Proc Jpn Acad Ser B Phys Biol Sci, 2016, 92(3): 77-97. https://doi.org/10.2183/pjab.92.77 PMID: 26972599 PMCID: PMC4925767

[76] Stone LC, Thorne LS, Weston CJ, Graham M, Hodges NJ. Cytoglobin expression in the hepatic stellate cell line HSCT6 is regulated by extracellular matrix proteins dependent on FAK-signalling. Fibrogenesis Tissue Repair, 2015, 8:15. https://doi.org/10.1186/s13069-015-0032-y PMID: 26300973 PMCID: PMC4546255

[77] De Minicis S, Seki E, Uchinami H, Kluwe J, Zhang Y, Brenner DA, Schwabe RF. Gene expression profiles during hepatic stellate cell activation in culture and in vivo. Gastroenterology, 2007, 132(5):1937-1946. https://doi.org/10.1053/ j.gastro.2007.02.033 PMID: 17484886

[78] Mederacke I, Hsu CC, Troeger JS, Huebener P, Mu X, Dapito DH, Pradere JP, Schwabe RF. Fate tracing reveals hepatic stellate cells as dominant contributors to liver fibrosis independent of its aetiology. Nat Commun, 2013, 4(1):2823. https://doi.org/10.1038/ncomms3823 PMID: 24264436 PMCID: PMC4059406 
[79] Nagatsuma K, Hano H, Murakami K, Shindo D, Matsumoto $Y$, Mitobe J, Tanaka K, Saito M, Maehashi H, Owada M, Ikegami M, Tsubota A, Ohkusa T, Aizawa Y, Takagi I, Tajiri H, Matsuura T. Hepatic stellate cells that coexpress LRAT and CRBP-1 partially contribute to portal fibrogenesis in patients with human viral hepatitis. Liver Int, 2014, 34(2):243-252. https://doi.org/10.1111/liv.12255 PMID: 23890161

[80] Levy MT, McCaughan GW, Marinos G, Gorrell MD. Intrahepatic expression of the hepatic stellate cell marker fibroblas activation protein correlates with the degree of fibrosis in hepatitis C virus infection. Liver, 2002, 22(2):93-101. https:// doi.org/10.1034/j.1600-0676.2002.01503.x PMID: 12028401

[81] Davis BH, Coll D, Beno DW. Retinoic acid suppresses the response to platelet-derived growth factor in human hepatic Ito-cell-like myofibroblasts: a post-receptor mechanism independent of raf/fos/jun/egr activation. Biochem J, 1993 294(Pt 3):785-791. https://doi.org/10.1042/bj2940785 PMID: 8379934 PMCID: PMC1134530

[82] Pinzani M. PDGF and signal transduction in hepatic stellate cells. Front Biosci, 2002, 7:d1720-d1726. https://doi.org/10. 2741/a875 PMID: 12133817

[83] Pinzani M, Milani S, Grappone C, Weber FL Jr, Gentilini P, Abboud HE. Expression of platelet-derived growth factor in a model of acute liver injury. Hepatology, 1994, 19(3):701-707. https://doi.org/10.1002/hep.1840190323 PMID: 8119696

[84] Heldin P, Pertoft $\mathrm{H}$, Nordlinder $\mathrm{H}$, Heldin $\mathrm{CH}$, Laurent TC. Differential expression of platelet-derived growth factor alphaand beta-receptors on fat-storing cells and endothelial cells of rat liver. Exp Cell Res, 1991, 193(2):364-369. https://doi.org/ 10.1016/0014-4827(91)90108-7 PMID: 1848517

[85] Pinzani M, Milani S, Herbst H, DeFranco R, Grappone C, Gentilini A, Caligiuri A, Pellegrini G, Ngo DV, Romanelli RG, Gentilini P. Expression of platelet-derived growth factor and its receptors in normal human liver and during active hepatic fibrogenesis. Am J Pathol, 1996, 148(3):785-800. PMID: 8774134 PMCID: PMC1861723

[86] Yu MC, Chen CH, Liang X, Wang L, Gandhi CR, Fung JJ, Lu L, Qian S. Inhibition of T-cell responses by hepatic stellate cells via B7-H1-mediated T-cell apoptosis in mice. Hepatology, 2004, 40(6):1312-1321. https://doi.org/10.1002/hep.20488 PMID: 15565659

[87] Cassiman D, Roskams T, van Pelt J, Libbrecht L, Aertsen P, Crabbé T, Vankelecom H, Denef C. Alpha B-crystallin expression in human and rat hepatic stellate cells. J Hepatol, 2001, 35(2):200-207. https://doi.org/10.1016/s0168-8278(01)0012 2-2 PMID: 11580142

[88] Murakami K, Abe T, Miyazawa M, Yamaguchi M, Masuda T, Matsuura T, Nagamori S, Takeuchi K, Abe K, Kyogoku M. Establishment of a new human cell line, LI90, exhibiting characteristics of hepatic Ito (fat-storing) cells. Lab Invest, 1995, 72(6):731-739. PMID: 7540235

[89] Migita K, Maeda Y, Abiru S, Nakamura M, Komori A, Yokoyama T, Takii Y, Mori T, Yatsuhashi H, Eguchi K, Ishibashi H. Immunosuppressant FK506 inhibits matrix metalloproteinase-9 induction in TNF-alpha-stimulated human hepatic stellate cells. Life Sci, 2006, 78(21):2510-2515. https://doi.org/ 10.1016/j.Ifs.2005.10.003 PMID: 16303143

[90] Weill FX, Blazejewski S, Blanc JF, Huet S, Gauthier JM, Neaud V, Olaso E, Dubuisson L, Azais-Braesco V, VidalVanaclocha F, Balabaud C, Bioulac-Sage P, Rosenbaum J. Characterization of a new human liver myofibroblast cell line: transcriptional regulation of plasminogen activator inhibitor type I by transforming growth factor beta 1. Lab Invest, 1997, 77(1):63-70. PMID: 9251679

[91] Schnabl B, Choi YH, Olsen JC, Hagedorn CH, Brenner DA. Immortal activated human hepatic stellate cells generated by ectopic telomerase expression. Lab Invest, 2002, 82(3): 323-333. https://doi.org/10.1038/labinvest.3780426 PMID: 11896211

[92] Schnabl B, Purbeck CA, Choi YH, Hagedorn CH, Brenner D. Replicative senescence of activated human hepatic stellate cells is accompanied by a pronounced inflammatory but less fibrogenic phenotype. Hepatology, 2003, 37(3):653-664. https://doi.org/10.1053/ihep.2003.50097 PMID: 12601363

[93] Xu L, Hui AY, Albanis E, Arthur MJ, O'Byrne SM, Blaner WS Mukherjee P, Friedman SL, Eng FJ. Human hepatic stellate cell lines, LX-1 and LX-2: new tools for analysis of hepatic fibrosis. Gut, 2005, 54(1):142-151. https://doi.org/10.1136/ gut.2004.042127 PMID: 15591520 PMCID: PMC1774377
[94] Zhao C, Chen W, Yang L, Chen L, Stimpson SA, Diehl AM. PPARgamma agonists prevent TGFbeta1/Smad3-signaling in human hepatic stellate cells. Biochem Biophys Res Commun, 2006, 350(2):385-391. https://doi.org/10.1016/j.bbrc.2006.09. 069 PMID: 17010940 PMCID: PMC1760476

[95] Rashid ST, Humphries JD, Byron A, Dhar A, Askari JA, Selley JN, Knight D, Goldin RD, Thursz M, Humphries MJ. Proteomic analysis of extracellular matrix from the hepatic stellate cell line LX-2 identifies CYR61 and Wnt-5a as novel constituents of fibrotic liver. J Proteome Res, 2012, 11(8):40524064. https://doi.org/10.1021/pr3000927 PMID: 22694338 PMCID: PMC3411196

[96] Ding N, Hah N, Yu RT, Sherman MH, Benner C, Leblanc M, He M, Liddle C, Downes M, Evans RM. BRD4 is a novel therapeutic target for liver fibrosis. Proc Natl Acad Sci U S A, 2015, 112(51):15713-15718. https://doi.org/10.1073/pnas.1 522163112 PMID: 26644586 PMCID: PMC4697417

[97] Ajat M, Molenaar M, Brouwers JFHM, Vaandrager $A B$, Houweling M, Helms JB. Hepatic stellate cells retain the capacity to synthesize retinyl esters and to store neutral lipids in small lipid droplets in the absence of LRAT. Biochim Biophys Acta Mol Cell Biol Lipids, 2017, 1862(2):176-187. https://doi.org/10.1016/j.bbalip.2016.10.013 PMID: 27815220

[98] Pan XP, Wang Y, Yu XP, Li JZ, Zhou N, Du WB, Zhang YH, Cao HC, Zhu DH, Chen Y, Li LJ. Establishment and characterization of an immortalized human hepatic stellate cell line for applications in co-culturing with immortalized human hepatocytes. Int J Med Sci, 2015, 12(3):248-255. https://doi.org/10.7150/ijms.11002 PMID: 25678842 PMCID: PMC4323363

[99] Shirakami Y, Lee SA, Clugston RD, Blaner WS. Hepatic metabolism of retinoids and disease associations. Biochim Biophys Acta, 2012, 1821(1):124-136. https://doi.org/10.1016/ j.bbalip.2011.06.023 PMID: 21763780 PMCID: PMC3488285

[100] O'Byrne SM, Blaner WS. Retinol and retinyl esters: biochemistry and physiology. J Lipid Res, 2013, 54(7):1731-1743. https:// doi.org/10.1194/jl.R037648 PMID: 23625372 PMCID: PMC 3679378

[101] Schreiber R, Taschler U, Preiss-Landl K, Wongsiriroj N Zimmermann R, Lass A. Retinyl ester hydrolases and their roles in vitamin A homeostasis. Biochim Biophys Acta, 2012, 1821(1):113-123. https://doi.org/10.1016/j.bbalip.2011.05. 001 PMID: 21586336 PMCID: PMC3242165

[102] Yamada M, Blaner WS, Soprano DR, Dixon JL, Kjeldbye HM, Goodman DS. Biochemical characteristics of isolated rat liver stellate cells. Hepatology, 1987, 7(6):1224-1229. https:// doi.org/10.1002/hep.1840070609 PMID: 2824313

[103] Higashi N, Imai K, Sato M, Sato T, Kojima N, Miura M, Wold HL, Moskaug J JØ, Berg T, Norum KR, Roos N, Wake K, Blomhoff R, Senoo H. Intralobular distribution of vitamin A-storing lipid droplets in hepatic stellate cells with special reference to polar bear and arctic fox. Comp Hepatol, 2004, 3(Suppl 1):S16. https://doi.org/10.1186/1476-59262-S1-S16 PMID: 14960168 PMCID: PMC2409438

[104] Senoo H, Yoshikawa K, Morii M, Miura M, Imai K, Mezaki Y. Hepatic stellate cell (vitamin A-storing cell) and its relative past, present and future. Cell Biol Int, 2010, 34(12):12471272. https://doi.org/10.1042/CBI20100321 PMID: 21067523

[105] Friedman SL, Wei S, Blaner WS. Retinol release by activated rat hepatic lipocytes: regulation by Kupffer cell-conditioned medium and PDGF. Am J Physiol, 1993, 264(5 Pt 1):G947G952. https://doi.org/10.1152/ajpgi.1993.264.5.G947 PMID: 8498521

[106] Straub BK, Stoeffel P, Heid H, Zimbelmann R, Schirmacher P. Differential pattern of lipid droplet-associated proteins and de novo perilipin expression in hepatocyte steatogenesis. Hepatology, 2008, 47(6):1936-1946. https://doi.org/10.1002/ hep.22268 PMID: 18393390

[107] Yamaguchi K, Yang L, McCall S, Huang J, Yu XX, Pandey SK, Bhanot S, Monia BP, Li YX, Diehl AM. Diacylglycerol acyltransferase 1 anti-sense oligonucleotides reduce hepatic fibrosis in mice with nonalcoholic steatohepatitis. Hepatology, 2007, 47(2):625-635. https://doi.org/10.1002/hep.21988 PMID: 18000880

[108] Yen CLE, Monetti M, Burri BJ, Farese RV Jr. The triacylglycerol synthesis enzyme DGAT1 also catalyzes the synthesis of diacylglycerols, waxes, and retinyl esters. J Lipid Res, 2005, 46(7):1502-1511. https://doi.org/10.1194/jlr.M50003 6-JLR200 PMID: 15834126 
[109] Orland MD, Anwar K, Cromley D, Chu CH, Chen L, Billheimer JT, Hussain MM, Cheng D. Acyl coenzyme A dependent retinol esterification by acyl coenzyme A: diacylglycerol acyltransferase 1. Biochim Biophys Acta, 2005 1737(1):76-82. https://doi.org/10.1016/j.bbalip.2005.09.003 PMID: 16214399

[110] Carmona R, Barrena S, Muñoz-Chápuli R. Retinoids in stellate cells: development, repair, and regeneration. J Dev Biol 2019, 7(2):10. https://doi.org/10.3390/jdb7020010 PMID: 31137700 PMCID: PMC6630434

[111] Bobowski-Gerard M, Zummo FP, Staels B, Lefebvre P Eeckhoute J. Retinoids issued from hepatic stellate cell lipid droplet loss as potential signaling molecules orchestrating a multicellular liver injury response. Cells, 2018, 7(9):137. https://doi.org/10.3390/cells7090137 PMID: 30217095 PMCID: PMC6162435

[112] Leo MA, Lieber CS. Hepatic vitamin A depletion in alcoholic liver injury. N Engl J Med, 1982, 307(10):597-601. https:// doi.org/10.1056/NEJM198209023071006 PMID: 7202119

[113] Cui X, Dang S, Wang Y, Chen Y, Zhou J, Shen C, Kuang Y, Fei J, Lu L, Wang Z. Retinol dehydrogenase 13 deficiency diminishes carbon tetrachloride-induced liver fibrosis in mice. Toxicol Lett, 2017, 265:17-22. https://doi.org/10.1016/j.tox let.2016.11.010 PMID: 27865848

[114] Yi HS, Lee YS, Byun JS, Seo W, Jeong JM, Park O Duester G, Haseba T, Kim SC, Park KG, Gao B, Jeong WI. Alcohol dehydrogenase III exacerbates liver fibrosis by enhancing stellate cell activation and suppressing natural killer cells in mice. Hepatology, 2014, 60(3):1044-1053. https://doi.org/10.1002/hep.27137 PMID: 24668648 PMCID: PMC4867000

[115] Taschler U, Schreiber R, Chitraju C, Grabner GF, Romauch M Wolinski H, Haemmerle G, Breinbauer R, Zechner R, Lass A, Zimmermann R. Adipose triglyceride lipase is involved in the mobilization of triglyceride and retinoid stores of hepatic stellate cells. Biochim Biophys Acta, 2015, 1851(7):937-945 https://doi.org/10.1016/j.bbalip.2015.02.017 PMID: 25732851 PMCID: PMC4408194

[116] Okuno M, Sato T, Kitamoto T, Imai S, Kawada N, Suzuki $Y$, Yoshimura $\mathrm{H}$, Moriwaki $\mathrm{H}$, Onuki K, Masushige S, Muto $\mathrm{Y}$, Friedman SL, Kato S, Kojima S. Increased 9,13-di-cis-retinoic acid in rat hepatic fibrosis: implication for a potential link between retinoid loss and TGF- $\beta$ mediated fibrogenesis in vivo. J Hepatol, 1999, 30(6):1073-1080. https://doi.org/ 10.1016/s0168-8278(99)80262-1 PMID: 10406186

[117] Zhou TB, Drummen GPC, Qin YH. The controversial role of retinoic acid in fibrotic diseases: analysis of involved signaling pathways. Int J Mol Sci, 2012, 14(1):226-243. https:// doi.org/10.3390/ijms14010226 PMID: 23344030 PMCID: PMC3565260

[118] Panebianco C, Oben JA, Vinciguerra M, Pazienza V. Senescence in hepatic stellate cells as a mechanism of liver fibrosis reversal: a putative synergy between retinoic acid and PPAR-gamma signalings. Clin Exp Med, 2017 17(3):269-280. https://doi.org/10.1007/s10238-016-0438-x PMID: 27655446

[119] Pirazzi C, Valenti L, Motta BM, Pingitore P, Hedfalk K, Mancina RM, Burza MA, Indiveri C, Ferro $Y$, Montalcini T, Maglio C, Dongiovanni P, Fargion S, Rametta R, Pujia A Andersson L, Ghosal S, Levin M, Wiklund O, lacovino M, Borén J, Romeo S. PNPLA3 has retinyl-palmitate lipase activity in human hepatic stellate cells. Hum Mol Genet, 2014 23(15):4077-4085. https://doi.org/10.1093/hmg/ddu121 PMID: 24670599 PMCID: PMC4082369

[120] Bruschi FV, Tardelli M, Claudel T, Trauner M. PNPLA3 expression and its impact on the liver: current perspectives. Hepat Med, 2017, 9:55-66. https://doi.org/10.2147/HMER. S125718 PMID: 29158695 PMCID: PMC5683790

[121] Bruschi FV, Claudel T, Tardelli M, Caligiuri A, Stulnig TM, Marra F, Trauner M. The PNPLA3 I148M variant modulates the fibrogenic phenotype of human hepatic stellate cells. Hepatology, 2017, 65(6):1875-1890. https://doi.org/10.1002/ hep.29041 PMID: 28073161

[122] Roskams T. Different types of liver progenitor cells and their niches. J Hepatol, 2006, 45(1):1-4. https://doi.org/10.1016/ j.jhep.2006.05.002 PMID: 16723168

[123] Baba S, Fujii H, Hirose T, Yasuchika K, Azuma H, Hoppo T, Naito M, Machimoto T, Ikai I. Commitment of bone marrow cells to hepatic stellate cells in mouse. J Hepatol, 2004 40(2):255-260. https://doi.org/10.1016/j.jhep.2003.10.012 PMID: 14739096
[124] Matsumoto K, Miki R, Nakayama M, Tatsumi N, Yokouchi Y. Wnt9a secreted from the walls of hepatic sinusoids is essential for morphogenesis, proliferation, and glycogen accumulation of chick hepatic epithelium. Dev Biol, 2008, 319(2):234-247. https://doi.org/10.1016/j.ydbio.2008.04.021 PMID: 18513713

[125] Maher JJ. Cell-specific expression of hepatocyte growth factor in liver. Upregulation in sinusoidal endothelial cells after carbon tetrachloride. J Clin Invest, 1993, 91(5):22442252. https://doi.org/10.1172/JCI116451 PMID: 7683700 PMCID: PMC288227

[126] Asahina K, Sato H, Yamasaki C, Kataoka M, Shiokawa M, Katayama S, Tateno C, Yoshizato K. Pleiotrophin/heparinbinding growth-associated molecule as a mitogen of rat hepatocytes and its role in regeneration and development of liver. Am J Pathol, 2002, 160(6):2191-2205. https://doi. org/10.1016/S0002-9440(10)61167-4 PMID: 12057922 PMCID: PMC1850835

[127] Mullhaupt B, Feren A, Fodor E, Jones A. Liver expression of epidermal growth factor RNA. Rapid increases in immediateearly phase of liver regeneration. J Biol Chem, 1994, 269(31): 19667-19670. PMID: 7519599

[128] Sekhon SS, Tan X, Micsenyi A, Bowen WC, Monga SPS. Fibroblast growth factor enriches the embryonic liver cultures for hepatic progenitors. Am J Pathol, 2004, 164(6):2229_ 2240. https://doi.org/10.1016/S0002-9440(10)63779-0 PMID: 15161655 PMCID: PMC1615755

[129] Berg T, Rountree CB, Lee L, Estrada J, Sala FG, Choe A, Veltmaat JM, De Langhe S, Lee R, Tsukamoto H, Crooks GM, Bellusci S, Wang KS. Fibroblast growth factor 10 is critical for liver growth during embryogenesis and controls hepatoblast survival via $\beta$-catenin activation. Hepatology, 2007, 46(4):11871197. https://doi.org/10.1002/hep.21814 PMID: 17668871 PMCID: PMC3494299

[130] Yin C, Evason KJ, Asahina K, Stainier DYR. Hepatic stellate cells in liver development, regeneration, and cancer. J Clin Invest, 2013, 123(5):1902-1910. https://doi.org/10.1172/JCI 66369 PMID: 23635788 PMCID: PMC3635734

[131] Libbrecht L, Cassiman D, Desmet V, Roskams T. The correlation between portal myofibroblasts and development of intrahepatic bile ducts and arterial branches in human liver. Liver, 2002, 22(3):252-258. https://doi.org/10.1046/ j.0106-9543.2002.01674.x PMID: 12100576

[132] Sawitza I, Kordes C, Reister S, Häussinger D. The niche of stellate cells within rat liver. Hepatology, 2009, 50(5):16171624. https://doi.org/10.1002/hep.23184 PMID: 19725107

[133] Zong Y, Panikkar A, Xu J, Antoniou A, Raynaud P, Lemaigre F, Stanger BZ. Notch signaling controls liver development by regulating biliary differentiation. Development, 2009, 136(10): 1727-1739. https://doi.org/10.1242/dev.029140 PMID: 19369401 PMCID: PMC2673761

[134] Kruglov EA, Nathanson RA, Nguyen T, Dranoff JA. Secretion of MCP-1/CCL2 by bile duct epithelia induces myofibroblastic transdifferentiation of portal fibroblasts. Am J Physiol Gastrointest Liver Physiol, 2006, 290(4):G765-G771. https://doi.org/ 10.1152/ajpgi.00308.2005 PMID: 16282363

[135] Kinnman N, Francoz C, Barbu V, Wendum D, Rey C, Hultcrantz R, Poupon R, Housset C. The myofibroblastic conversion of peribiliary fibrogenic cells distinct from hepatic stellate cells is stimulated by platelet-derived growth factor during liver fibrogenesis. Lab Invest, 2003, 83(2):163-173. https://doi.org/10.1097/01.lab.0000054178.01162.e4 PMID: 12594232

[136] Schmitt-Graeff A, Jing R, Nitschke R, Desmoulière A, Skalli O. Synemin expression is widespread in liver fibrosis and is induced in proliferating and malignant biliary epithelial cells. Hum Pathol, 2006, 37(9):1200-1210. https://doi.org/10.10 16/j.humpath.2006.04.017 PMID: 16938526

[137] Hellström M, Kalén M, Lindahl P, Abramsson A, Betsholtz C. Role of PDGF-B and PDGFR-beta in recruitment of vascular smooth muscle cells and pericytes during embryonic blood vessel formation in the mouse. Development, 1999, 126(14): 3047-3055. PMID: 10375497

[138] Semela D, Das A, Langer D, Kang N, Leof E, Shah V. Platelet-derived growth factor signaling through ephrin-b2 regulates hepatic vascular structure and function. Gastroenterology, 2008, 135(2):671-679. https://doi.org/10.1053/ j.gastro.2008.04.010 PMID: 18570897 PMCID: PMC2639748 
[139] Berg T, DeLanghe S, Al Alam D, Utley S, Estrada J, Wang KS $\beta$-Catenin regulates mesenchymal progenitor cell differentiation during hepatogenesis. J Surg Res, 2010, 164(2):276-285. https://doi.org/10.1016/j.jss.2009.10.033 PMID: 20381814 PMCID: PMC2904820

[140] Hentsch B, Lyons I, Li R, Hartley L, Lints TJ, Adams JM, Harvey RP. HIx homeo box gene is essential for an inductive tissue interaction that drives expansion of embryonic liver and gut. Genes Dev, 1996, 10(1):70-79. https://doi.org/10. 1101/gad.10.1.70 PMID: 8557196

[141] Kubota H, Yao HL, Reid LM. Identification and characterization of vitamin A-storing cells in fetal liver: implications for functional importance of hepatic stellate cells in liver development and hematopoiesis. Stem Cells, 2007, 25(9): 2339-2349. https://doi.org/10.1634/stemcells.2006-0316 PMID: 17585172

[142] Kordes C, Sawitza I, Müller-Marbach A, Ale-Agha N, Keitel V, Klonowski-Stumpe H, Häussinger D. CD133+ hepatic stellate cells are progenitor cells. Biochem Biophys Res Commun 2007, 352(2):410-417. https://doi.org/10.1016/j.bbrc.2006. 11.029 PMID: 17118341

[143] Rizzo S, Attard G, Hudson DL. Prostate epithelial stem cells. Cell Prolif, 2005, 38(6):363-374. https://doi.org/10.1111/j. 1365-2184.2005.00356.x PMID: 16300650 PMCID: PMC 6496238

[144] Yu Y, Fuhr J, Boye E, Gyorffy S, Soker S, Atala A, Mulliken JB, Bischoff $\mathrm{J}$. Mesenchymal stem cells and adipogenesis in hemangioma involution. Stem Cells, 2006, 24(6):1605-1612. https://doi.org/10.1634/stemcells.2005-0298 PMID: 16456130

[145] O'Brien CA, Pollett A, Gallinger S, Dick JE. A human colon cancer cell capable of initiating tumour growth in immunodeficient mice. Nature, 2007, 445(7123):106-110. https:// doi.org/10.1038/nature05372 PMID: 17122772

[146] Ricci-Vitiani L, Lombardi DG, Pilozzi E, Biffoni M, Todaro M, Peschle C, De Maria R. Identification and expansion of human colon-cancer-initiating cells. Nature, 2007, 445(7123):111115. https://doi.org/10.1038/nature05384 PMID: 17122771

[147] Rutherford A, Chung RT. Acute liver failure: mechanisms of hepatocyte injury and regeneration. Semin Liver Dis, 2008, 28(2):167-174. https://doi.org/10.1055/s-2008-1073116 PMID: 18452116

[148] Curado S, Stainier DYR. deLiver'in regeneration: injury response and development. Semin Liver Dis, 2010, 30(3): 288-295. https://doi.org/10.1055/s-0030-1255357 PMID: 20665380

[149] Preziosi ME, Monga SP. Update on the mechanisms of liver regeneration. Semin Liver Dis, 2017, 37(2):141-151. https://doi.org/10.1055/s-0037-1601351 PMID: 28564722 PMCID: PMC5700459

[150] Roskams T. Relationships among stellate cell activation, progenitor cells, and hepatic regeneration. Clin Liver Dis, 2008, 12(4):853-860. ix. https://doi.org/10.1016/j.cld.2008. 07.014 PMID: 18984470

[151] Yang L, Jung Y, Omenetti A, Witek RP, Choi S, Vandongen HM, Huang J, Alpini GD, Diehl AM. Fate-mapping evidence that hepatic stellate cells are epithelial progenitors in adult mouse livers. Stem Cells, 2008, 26(8):2104-2113. https://doi.org/ 10.1634/stemcells.2008-0115 PMID: 18511600 PMCID: PMC3633413

[152] Shen K, Chang W, Gao X, Wang H, Niu W, Song L, Qin X. Depletion of activated hepatic stellate cell correlates with severe liver damage and abnormal liver regeneration in acetaminophen-induced liver injury. Acta Biochim Biophys Sin (Shanghai), 2011, 43(4):307-315. https://doi.org/10.1093/ abbs/gmr005 PMID: 21335335

[153] Kostallari E, Shah VH. Pericytes in the liver. Adv Exp Med Biol, 2019, 1122:153-167. https://doi.org/10.1007/978-3-0 30-11093-2 9 PMID: 30937868 PMCID: PMC7137998

[154] Pintilie DG, Shupe TD, Oh SH, Salganik SV, Darwiche H, Petersen BE. Hepatic stellate cells' involvement in progenitormediated liver regeneration. Lab Invest, 2010, 90(8):11991208. https://doi.org/10.1038/labinvest.2010.88 PMID: 20440274 PMCID: PMC2912420

[155] Chen L, Zhang W, Zhou QD, Yang HQ, Liang HF, Zhang BX, Long X, Chen XP. HSCs play a distinct role in different phases of oval cell-mediated liver regeneration. Cell Biochem Funct, 2012, 30(7):588-596. https://doi.org/10.1002/cbf.2838 PMID: 22535704
[156] Passino MA, Adams RA, Sikorski SL, Akassoglou K. Regulation of hepatic stellate cell differentiation by the neurotrophin receptor p75NTR. Science, 2007, 315(5820): 1853-1856. https://doi.org/10.1126/science.1137603 PMID: 17395831

[157] Yang L, Wang Y, Mao H, Fleig S, Omenetti A, Brown KD, Sicklick JK, Li YX, Diehl AM. Sonic hedgehog is an autocrine viability factor for myofibroblastic hepatic stellate cells. J Hepatol, 2008, 48(1):98-106. https://doi.org/10.1016/ j.jhep.2007.07.032 PMID: 18022723 PMCID: PMC2196213

[158] Ochoa B, Syn WK, Delgado I, Karaca GF, Jung Y, Wang J, Zubiaga AM, Fresnedo O, Omenetti A, Zdanowicz M, Choi SS, Diehl AM. Hedgehog signaling is critical for normal liver regeneration after partial hepatectomy in mice. Hepatology, 2010, 51(5):1712-1723. https://doi.org/10.1002/hep.23525 PMID: 20432255 PMCID: PMC2920129

[159] Schuppan D, Schmid M, Somasundaram R, Ackermann R, Ruehl M, Nakamura T, Riecken EO. Collagens in the liver extracellular matrix bind hepatocyte growth factor. Gastroenterology, 1998, 114(1):139-152. https://doi.org/10.1016/ s0016-5085(98)70642-0 PMID: 9428228

[160] Pi L, Ding X, Jorgensen M, Pan JJ, Oh SH, Pintilie D, Brown A, Song WY, Petersen BE. Connective tissue growth factor with a novel fibronectin binding site promotes cell adhesion and migration during rat oval cell activation. Hepatology, 2008, 47(3):996-1004. https://doi.org/10.1002/ hep.22079 PMID: 18167060 PMCID: PMC3130595

[161] Taub R. Liver regeneration: from myth to mechanism. Nat Rev Mol Cell Biol, 2004, 5(10):836-847. https://doi.org/10. 1038/nrm1489 PMID: 15459664

[162] Karkampouna S, Ten Dijke P, Dooley S, Julio MK. TGF $\beta$ signaling in liver regeneration. Curr Pharm Des, 2012, 18(27): 4103-4113. https://doi.org/10.2174/138161212802430521 PMID: 22630085

[163] Ebrahimkhani MR, Oakley F, Murphy LB, Mann J, Moles A, Perugorria MJ, Ellis E, Lakey $A F$, Burt $A D$, Douglass $A$, Wright MC, White SA, Jaffré F, Maroteaux L, Mann DA. Stimulating healthy tissue regeneration by targeting the $5-\mathrm{HT}_{2} \mathrm{~B}$ receptor in chronic liver disease. Nat Med, 2011, 17(12):1668-1673. https://doi.org/10.1038/nm.2490 PMID: 22120177 PMCID: PMC3428919

[164] Curado S, Anderson RM, Jungblut B, Mumm J, Schroeter E, Stainier DYR. Conditional targeted cell ablation in zebrafish: a new tool for regeneration studies. Dev Dyn, 2007, 236(4): 1025-1035. https://doi.org/10.1002/dvdy.21100 PMID: 17326133

[165] Curado S, Ober EA, Walsh S, Cortes-Hernandez P, Verkade $\mathrm{H}$, Koehler CM, Stainier DY. The mitochondrial import gene tomm22 is specifically required for hepatocyte survival and provides a liver regeneration model. Dis Model Mech, 2010, 3(7-8):486-495. https://doi.org/10.1242/dmm. 004390 PMID: 20483998 PMCID: PMC2898538

[166] Yin C, Evason KJ, Maher JJ, Stainier DYR. The basic helix-loop-helix transcription factor, heart and neural crest derivatives expressed transcript 2 , marks hepatic stellate cells in zebrafish: analysis of stellate cell entry into the developing liver. Hepatology, 2012, 56(5):1958-1970. https:// doi.org/10.1002/hep.25757 PMID: 22488653 PMCID: PMC 3407311

[167] Maher JJ. Interactions between hepatic stellate cells and the immune system. Semin Liver Dis, 2001, 21(3):417-426. https://doi.org/10.1055/s-2001-17555 PMID: 11586469

[168] Dranoff JA, Ogawa M, Kruglov EA, Gaça MD, Sévigny J, Robson SC, Wells RG. Expression of P2Y nucleotide receptors and ectonucleotidases in quiescent and activated rat hepatic stellate cells. Am J Physiol Gastrointest Liver Physiol, 2004, 287(2):G417-G424. https://doi.org/10.1152/ajpgi.00294.2003 PMID: 14764443 PMCID: PMC5241161

[169] Racine-Samson L, Rockey DC, Bissell DM. The role of alpha1beta1 integrin in wound contraction. A quantitative analysis of liver myofibroblasts in vivo and in primary culture. J Biol Chem, 1997, 272(49):30911-30917. https://doi.org/ 10.1074/jbc.272.49.30911 PMID: 9388237

[170] Schwabe RF, Bataller R, Brenner DA. Human hepatic stellate cells express CCR5 and RANTES to induce proliferation and migration. Am J Physiol Gastrointest Liver Physiol, 2003, 285(5):G949-G958. https://doi.org/10.1152/ajpgi.00 215.2003 PMID: 12829440 
[171] Bonacchi A, Petrai I, Defranco RM, Lazzeri E, Annunziato F Efsen E, Cosmi L, Romagnani P, Milani S, Failli P, Batignani G, Liotta F, Laffi G, Pinzani M, Gentilini P, Marra F. The chemokine CCL21 modulates lymphocyte recruitment and fibrosis in chronic hepatitis C. Gastroenterology, 2003 125(4):1060-1076. https://doi.org/10.1016/s0016-5085(03) 01194-6 PMID: 14517790

[172] Seki E, De Minicis S, Osterreicher $\mathrm{CH}$, Kluwe J, Osawa Y, Brenner DA, Schwabe RF. TLR4 enhances TGF- $\beta$ signaling and hepatic fibrosis. Nat Med, 2007, 13(11):1324-1332. https://doi.org/10.1038/nm1663 PMID: 17952090

[173] Marra F, Tacke F. Roles for chemokines in liver disease. Gastroenterology, 2014, 147(3):577-594. https://doi.org/10. 1053/j.gastro.2014.06.043 PMID: 25066692

[174] Karlmark KR, Zimmermann HW, Roderburg C, Gassler N, Wasmuth HE, Luedde T, Trautwein C, Tacke F. The fractalkine receptor $\mathrm{CX} 3 \mathrm{CR} 1$ protects against liver fibrosis by controlling differentiation and survival of infiltrating hepatic monocytes. Hepatology, 2010, 52(5):1769-1782. https:// doi.org/10.1002/hep.23894 PMID: 21038415

[175] Safadi R, Ohta M, Alvarez CE, Fiel MI, Bansal M, Mehal WZ Friedman SL. Immune stimulation of hepatic fibrogenesis by CD8 cells and attenuation by transgenic interleukin-10 from hepatocytes. Gastroenterology, 2004, 127(3):870-882. https://doi.org/10.1053/j.gastro.2004.04.062 PMID: 15362042

[176] Unanue ER. Ito cells, stellate cells, and myofibroblasts: new actors in antigen presentation. Immunity, 2007, 26(1):9-10. https://doi.org/10.1016/j.immuni.2007.01.001 PMID: 17241956

[177] Viñas O, Bataller R, Sancho-Bru P, Ginès P, Berenguer C, Enrich C, Nicolás JM, Ercilla G, Gallart T, Vives J, Arroyo V, Rodés J. Human hepatic stellate cells show features of antigen-presenting cells and stimulate lymphocyte proliferation. Hepatology, 2003, 38(4):919-929. https://doi.org/10. 1053/jhep.2003.50392 PMID: 14512879

[178] Winau F, Hegasy G, Weiskirchen R, Weber S, Cassan C Sieling PA, Modlin RL, Liblau RS, Gressner AM, Kaufmann SH. Ito cells are liver-resident antigen-presenting cells for activating T cell responses. Immunity, 2007, 26(1):117-129. https:// doi.org/10.1016/j.immuni.2006.11.011 PMID: 17239632

[179] Kobayashi S, Seki S, Kawada N, Morikawa H, Nakatani K, Uyama N, Ikeda K, Nakajima Y, Arakawa T, Kaneda K. Apoptosis of $T$ cells in the hepatic fibrotic tissue of the rat: a possible inducing role of hepatic myofibroblast-like cells. Cell Tissue Res, 2003, 311(3):353-364. https://doi.org/10. 1007/s00441-002-0670-4 PMID: 12658443

[180] Ichikawa S, Mucida D, Tyznik AJ, Kronenberg M, Cheroutre H. Hepatic stellate cells function as regulatory bystanders. J Immunol, 2011, 186(10):5549-5555. https://doi.org/10.40 49/jimmunol.1003917 PMID: 21460203 PMCID: PMC3132534

[181] Dunham RM, Thapa M, Velazquez VM, Elrod EJ, Denning TL, Pulendran B, Grakoui A. Hepatic stellate cells preferentially induce Foxp3+ regulatory $\mathrm{T}$ cells by production of retinoic acid. J Immunol, 2013, 190(5):2009-2016. https://doi.org/ 10.4049/jimmunol.1201937 PMID: 23359509 PMCID: PMC 3575565

[182] Schildberg FA, Wojtalla A, Siegmund SV, Endl E, Diehl L, Abdullah Z, Kurts C, Knolle PA. Murine hepatic stellate cells veto CD8 T cell activation by a CD54-dependent mechanism Hepatology, 2011, 54(1):262-272. https://doi.org/10.1002/ hep.24352 PMID: 21488077

[183] Casini A, Pellegrini G, Ceni E, Salzano R, Parola M, Robino G, Milani S, Dianzani MU, Surrenti C. Human hepatic stellate cells express class I alcohol dehydrogenase and aldehyde dehydrogenase but not cytochrome P4502E1. J Hepatol, 1998, 28(1):40-45. https://doi.org/10.1016/s0168-8278(98) 80200-6 PMID: 9537862

[184] Yamauchi M, Potter JJ, Mezey E. Characteristics of alcoho dehydrogenase in fat-storing (Ito) cells of rat liver. Gastroenterology, 1988, 94(1):163-169. https://doi.org/10.1016/ 0016-5085(88)90625-7 PMID: 3335287

[185] March S, Graupera M, Rosa Sarrias M, Lozano F, Pizcueta P, Bosch J, Engel P. Identification and functional characterization of the hepatic stellate cell CD38 cell surface molecule. Am J Pathol, 2007, 170(1):176-187. https://doi. org/10.2353/ajpath.2007.051212 PMID: 17200192 PMCID: PMC1762705

[186] Parola M, Robino G, Bordone R, Leonarduzzi G, Casini A Pinzani M, Neve E, Bellomo G, Dianzani MU, IngelmanSundberg M, Albano E. Detection of cytochrome P4503A
(CYP3A) in human hepatic stellate cells. Biochem Biophys Res Commun, 1997, 238(2):420-424. https://doi.org/10.10 06/bbrc.1997.7307 PMID: 9299524

[187] Yamada T, Imaoka S, Kawada N, Seki S, Kuroki T, Kobayashi K, Monna T, Funae Y. Expression of cytochrome P450 isoforms in rat hepatic stellate cells. Life Sci, 1997, 61(2):171-179. https://doi.org/10.1016/s0024-3205(97)003 72-x PMID: 9217276

[188] Lee SJ, Friedman SL, Whalen R, Boyer TD. Cellular sources of glutathione S-transferase $\mathrm{P}$ in primary cultured rat hepatocytes: localization by in situ hybridization. Biochem J, 1994, 299(Pt 1):79-83. https://doi.org/10.1042/bj2990079 PMID: 8166662 PMCID: PMC1138023

[189] DeLeve LD. Glutathione defense in non-parenchymal cells. Semin Liver Dis, 1998, 18(4):403-413. https://doi.org/10. 1055/s-2007-1007173 PMID: 9875557

[190] Maher JJ, Neuschwander-Tetri BA. Manipulation of glutathione stores in rat hepatic stellate cells does not alter collagen synthesis. Hepatology, 1997, 26(3):618-623. https://doi.org/ 10.1002/hep.510260313 PMID: 9303491

[191] Lalazar A, Wong L, Yamasaki G, Friedman SL. Early genes induced in hepatic stellate cells during wound healing. Gene, 1997, 195(2):235-243. https://doi.org/10.1016/s0378-1119 (97)00159-5 PMID: 9305769

[192] De Bleser PJ, Xu G, Rombouts K, Rogiers V, Geerts A. Glutathione levels discriminate between oxidative stress and transforming growth factor-beta signaling in activated rat hepatic stellate cells. J Biol Chem, 1999, 274(48):3388133887. https://doi.org/10.1074/jbc.274.48.33881 PMID: 10567349

[193] Maher JJ, Saito JM, Neuschwander-Tetri BA. Glutathione regulation in rat hepatic stellate cells. Comparative studies in primary culture and in liver injury in vivo. Biochem Pharmacol, 1997, 53(5):637-641. https://doi.org/10.1016/s0006-2952(96) 00865-9 PMID: 9113082

[194] Kim KY, Rhim T, Choi I, Kim SS. N-acetylcysteine induces cell cycle arrest in hepatic stellate cells through its reducing activity. J Biol Chem, 2001, 276(44):40591-40598. https:// doi.org/10.1074/jbc.M100975200 PMID: 11509553

[195] Di Sario A, Baroni GS, Bendia E, D’Ambrosio L, Ridolfi F, Marileo JR, Jezequel AM, Benedetti A. Characterization of ion transport mechanisms regulating intracellular $\mathrm{pH}$ in hepatic stellate cells. Am J Physiol, 1997, 273(1 Pt 1):G39-G48. https://doi.org/10.1152/ajpgi.1997.273.1.G39 PMID: 9252507

[196] Svegliati-Baroni G, Di Sario A, Casini A, Ferretti G, D'Ambrosio L, Ridolfi F, Bolognini L, Salzano R, Orlandi F, Benedetti $A$. The $\mathrm{Na}^{+} / \mathrm{H}^{+}$exchanger modulates the fibrogenic effect of oxidative stress in rat hepatic stellate cells. J Hepatol, 1999, 30(5):868-875. https://doi.org/10.1016/s0168-8278(99) 80141-x PMID: 10365814

[197] Paik YH, Kim J, Aoyama T, De Minicis S, Bataller R, Brenner DA. Role of NADPH oxidases in liver fibrosis. Antioxid Redox Signal, 2014, 20(17):2854-2872. https:// doi.org/10.1089/ars.2013.5619 PMID: 24040957 PMCID: PMC4026397

[198] Adachi T, Togashi H, Suzuki A, Kasai S, Ito J, Sugahara K, Kawata S. NAD(P)H oxidase plays a crucial role in PDGFinduced proliferation of hepatic stellate cells. Hepatology, 2005, 41(6):1272-1281. https://doi.org/10.1002/hep.20719 PMID: 15915457

[199] Bataller R, Schwabe RF, Choi YH, Yang L, Paik YH, Lindquist J, Qian T, Schoonhoven $\mathrm{R}$, Hagedorn $\mathrm{CH}$, Lemasters JJ, Brenner DA. NADPH oxidase signal transduces angiotensin II in hepatic stellate cells and is critical in hepatic fibrosis. J Clin Invest, 2003, 112(9):1383-1394. https://doi.org/10.1172/JCI18212 PMID: 14597764 PMCID: PMC228420

[200] Zhan SS, Jiang JX, Wu J, Halsted C, Friedman SL, Zern MA, Torok NJ. Phagocytosis of apoptotic bodies by hepatic stellate cells induces NADPH oxidase and is associated with liver fibrosis in vivo. Hepatology, 2006, 43(3):435-443. https:// doi.org/10.1002/hep.21093 PMID: 16496318

[201] Ramadori G, Rieder H, Theiss F, Meyer zum Büschenfelde KH. Fat-storing (Ito) cells of rat liver synthesize and secrete apolipoproteins: comparison with hepatocytes. Gastroenterology, 1989, 97(1):163-172. https://doi.org/10.1016/0016-5085(89) 91431-5 PMID: 2721867

[202] Majack RA, Castle CK, Goodman LV, Weisgraber KH, Mahley RW, Shooter EM, Gebicke-Haerter PJ. Expression of apolipoprotein $\mathrm{E}$ by cultured vascular smooth muscle cells 
is controlled by growth state. J Cell Biol, 1988, 107(3):12071213. https://doi.org/10.1083/jcb.107.3.1207 PMID: 2458361 PMCID: PMC2115305

[203] Ferré N, Martínez-Clemente M, López-Parra M, GonzálezPériz A, Horrillo R, Planagumà A, Camps J, Joven J, Tres A Guardiola F, Bataller R, Arroyo V, Clària J. Increased susceptibility to exacerbated liver injury in hypercholesterolemic ApoE-deficient mice: potential involvement of oxysterols. Am J Physiol Gastrointest Liver Physiol, 2009 296(3):G553-G562. https://doi.org/10.1152/ajpgi.00547.2007 PMID: 19136384

[204] Ramadori G, Knittel T, Schwögler S, Bieber F, Rieder H, Meyer zum Büschenfelde KH. Dexamethasone modulates alpha 2-macroglobulin and apolipoprotein $\mathrm{E}$ gene expression in cultured rat liver fat-storing (Ito) cells. Hepatology, 1991, 14(5):875-882. https://doi.org/10.1002/hep.1840140520 PMID: 1718836

[205] Athari A, Hänecke K, Jungermann K. Prostaglandin F2 alpha and D2 release from primary Ito cell cultures after stimulation with noradrenaline and ATP but not adenosine. Hepatology, 1994, 20(1 Pt 1):142-148. https://doi.org/10. 1016/0270-9139(94)90146-5 PMID: 8020883

[206] Flisiak R, Baraona E, Li J, Lieber CS. Effects of ethanol on prostanoid production by liver fat-storing cells. Hepatology, 1993, 18(1):153-159. PMID: 8325606

[207] Beno DW, Mullen J, Davis BH. Lipoxygenase inhibitors block PDGF-induced mitogenesis: a MAPK-independent mechanism that blocks fos and egr. Am J Physiol, 1995, 268(3 Pt 1): C604-C610. https://doi.org/10.1152/ajpcell.1995.268.3.C604 PMID: 7900768

[208] Bachem MG, Meyer D, Melchior R, Sell KM, Gressner AM. Activation of rat liver perisinusoidal lipocytes by transforming growth factors derived from myofibroblastlike cells. A potential mechanism of self perpetuation in liver fibrogenesis. J Clin Invest, 1992, 89(1):19-27. https://doi.org/10.1172/JCI115561 PMID: 1729271 PMCID: PMC442814

[209] Meyer DH, Bachem MG, Gressner AM. Modulation of hepatic lipocyte proteoglycan synthesis and proliferation by Kupffer cell-derived transforming growth factors type beta 1 and type alpha. Biochem Biophys Res Commun, 1990, 171(3):11221129. https://doi.org/10.1016/0006-291x(90)90801-s PMID: 1699522

[210] Schirmacher P, Geerts A, Jung W, Pietrangelo A, Rogler CE, Dienes HP. The role of Ito cells in the biosynthesis of HGFSF in the liver. EXS, 1993, 65:285-299. PMID: 8380738

[211] Fujio K, Evarts RP, Hu Z, Marsden ER, Thorgeirsson SS. Expression of stem cell factor and its receptor, c-kit, during liver regeneration from putative stem cells in adult rat. Lab Invest, 1994, 70(4):511-516. PMID: 7513770

[212] Pinzani M, Abboud HE, Aron DC. Secretion of insulin-like growth factor-I and binding proteins by rat liver fat-storing cells: regulatory role of platelet-derived growth factor. Endocrinology, 1990, 127(5):2343-2349. https://doi.org/10.1210/ endo-127-5-2343 PMID: 1699746

[213] Zindy F, Lamas E, Schmidt S, Kirn A, Brechot C. Expression of insulin-like growth factor II (IGF-II) and IGF-II, IGF-I and insulin receptors mRNAs in isolated non-parenchymal rat liver cells. J Hepatol, 1992, 14(1):30-34. https://doi.org/10. 1016/ 0168-8278(92)90127-b PMID: 1310705

[214] Pinzani M, Abboud HE, Gesualdo L, Abboud SL. Regulation of macrophage colony-stimulating factor in liver fat-storing cells by peptide growth factors. Am J Physiol, 1992, 262(4 Pt 1): C876-C881. https://doi.org/10.1152/ajpcell.1992.262.4.C876 PMID: 1566815

[215] Pinzani M, Gesualdo L, Sabbah GM, Abboud HE. Effects of platelet-derived growth factor and other polypeptide mitogens on DNA synthesis and growth of cultured rat liver fat-storing cells. J Clin Invest, 1989, 84(6):1786-1793. https://doi.org/ 10.1172/JCI114363 PMID: 2592560 PMCID: PMC304056

[216] Pinzani M, Knauss TC, Pierce GF, Hsieh P, Kenney W, Dubyak GR, Abboud HE. Mitogenic signals for plateletderived growth factor isoforms in liver fat-storing cells. Am J Physiol, 1991, 260(3 Pt 1):C485-C491. https://doi.org/10. 1152/ajpcell.1991.260.3.C485 PMID: 2003575

[217] Marra F, Choudhury GG, Pinzani M, Abboud HE. Regulation of platelet-derived growth factor secretion and gene expression in human liver fat-storing cells. Gastroenterology, 1994 107(4):1110-1117. https://doi.org/10.1016/0016-5085(94)90 236-4 PMID: 7926460
[218] Wong L, Yamasaki G, Johnson RJ, Friedman SL. Induction of beta-platelet-derived growth factor receptor in rat hepatic lipocytes during cellular activation in vivo and in culture. J Clin Invest, 1994, 94(4):1563-1569. https://doi.org/10. 1172/JCI117497 PMID: 7929832 PMCID: PMC295310

[219] Czochra P, Klopcic B, Meyer E, Herkel J, Garcia-Lazaro JF, Thieringer F, Schirmacher P, Biesterfeld S, Galle PR, Lohse AW, Kanzler S. Liver fibrosis induced by hepatic overexpression of PDGF-B in transgenic mice. J Hepatol, 2006, 45(3):419-428. https://doi.org/10.1016/j.jhep.2006.04. 010 PMID: 16842882

[220] Marsden ER, Hu Z, Fujio K, Nakatsukasa H, Thorgeirsson SS, Evarts RP. Expression of acidic fibroblast growth factor in regenerating liver and during hepatic differentiation. Lab Invest, 1992, 67(4):427-433. PMID: 1279268

[221] Marra F, Valente AJ, Pinzani M, Abboud HE. Cultured human liver fat-storing cells produce monocyte chemotactic protein-1. Regulation by proinflammatory cytokines. J Clin Invest, 1993, 92(4):1674-1680. https://doi.org/10.1172/JCl116753 PMID: 8408620 PMCID: PMC288326

[222] Pinzani M, Carloni V, Marra F, Riccardi D, Laffi G, Gentilini P. Biosynthesis of platelet-activating factor and its 10-acyl analogue by liver fat-storing cells. Gastroenterology, 1994, 106(5):1301-1311. https://doi.org/10.1016/0016-5085(94)90 023-x PMID: 8174891

[223] Yang Y, Nemoto EM, Harvey SAK, Subbotin VM, Gandhi CR. Increased hepatic platelet activating factor (PAF) and PAF receptors in carbon tetrachloride induced liver cirrhosis. Gut, 2004, 53(6):877-883. https://doi.org/10.1136/gut.2003. 024893 PMID: 15138217 PMCID: PMC1774060

[224] Maher JJ, Lozier JS, Scott MK. Rat hepatic stellate cells produce cytokine-induced neutrophil chemoattractant in culture and in vivo. Am J Physiol, 1998, 275(4):G847-G853. https://doi.org/10.1152/ajpgi.1998.275.4.G847 PMID: 9756517

[225] Canbay A, Feldstein A, Baskin-Bey E, Bronk SF, Gores GJ. The caspase inhibitor IDN-6556 attenuates hepatic injury and fibrosis in the bile duct ligated mouse. J Pharmacol Exp Ther, 2004, 308(3):1191-1196. https://doi.org/10.1124/jpet. 103.060129 PMID: 14617689

[226] Marra F. Chemokines in liver inflammation and fibrosis. Front Biosci, 2002, 7:d1899-d1914. PMID: 12161342

[227] Greenwel P, Rubin J, Schwartz M, Hertzberg EL, Rojkind M. Liver fat-storing cell clones obtained from a $\mathrm{CCl}_{4}$-cirrhotic rat are heterogeneous with regard to proliferation, expression of extracellular matrix components, interleukin- 6 , and connexin 43. Lab Invest, 1993, 69(2):210-216. PMID: 8394478

[228] Tiggelman AM, Boers W, Linthorst C, Brand HS, Sala M, Chamuleau RA. Interleukin-6 production by human liver (myo)fibroblasts in culture. Evidence for a regulatory role of LPS, IL-1 beta and TNF alpha. J Hepatol, 1995, 23(3):295306. PMID: 8550994

[229] Thompson K, Maltby J, Fallowfield J, McAulay M, MillwardSadler $\mathrm{H}$, Sheron $\mathrm{N}$. Interleukin-10 expression and function in experimental murine liver inflammation and fibrosis. Hepatology, 1998, 28(6):1597-1606. https://doi.org/10.1002/ hep.510280620 PMID: 9828224

[230] Hellerbrand, Wang SC, Tsukamoto H, Brenner DA, Rippe RA. Expression of intracellular adhesion molecule 1 by activated hepatic stellate cells. Hepatology, 1996, 24(3):670-676. https://doi.org/10.1002/hep.510240333 PMID: 8781341

[231] Knittel T, Dinter C, Kobold D, Neubauer K, Mehde M, Eichhorst $S$, Ramadori G. Expression and regulation of cell adhesion molecules by hepatic stellate cells (HSC) of rat liver: involvement of $\mathrm{HSC}$ in recruitment of inflammatory cells during hepatic tissue repair. Am J Pathol, 1999, 154(1): 153-167. https://doi.org/10.1016/s0002-9440(10)65262-5 PMID: 9916930 PMCID: PMC1853435

[232] Knittel T, Aurisch S, Neubauer K, Eichhorst S, Ramadori G. Cell-type-specific expression of neural cell adhesion molecule (N-CAM) in Ito cells of rat liver. Up-regulation during in vitro activation and in hepatic tissue repair. Am J Pathol, 1996, 149(2):449-462. PMID: 8701984 PMCID: PMC1865318

[233] Nakatani K, Seki S, Kawada N, Kobayashi K, Kaneda K. Expression of neural cell adhesion molecule (N-CAM) in perisinusoidal stellate cells of the human liver. Cell Tissue Res, 1996, 283(1):159-165. https://doi.org/10.1007/s0044 10050524 PMID: 8581955 
[234] Nakatani K, Tanaka H, Ikeda K, Sakabe M, Kadoya H, Seki S, Kaneda K, Nakajima Y. Expression of NCAM in activated portal fibroblasts during regeneration of the rat liver after partial hepatectomy. Arch Histol Cytol, 2006, 69(1): 61-72. https://doi.org/10.1679/aohc.69.61 PMID: 16609270

[235] de Bleser PJ, Jannes P, van Buul-Offers SC, Hoogerbrugge CM, van Schravendijk CF, Niki T, Rogiers V, van den Brande JL, Wisse E, Geerts A. Insulinlike growth factor-II/mannose 6phosphate receptor is expressed on $\mathrm{CCl}_{4}$-exposed rat fatstoring cells and facilitates activation of latent transforming growth factor-beta in cocultures with sinusoidal endothelial cells. Hepatology, 1995, 21(5):1429-1437. https://doi.org/10. 1002/hep.1840210529 PMID: 7737649

[236] Gressner AM. Cytokines and cellular crosstalk involved in the activation of fat-storing cells. J Hepatol, 1995, 22(2 Suppl): 28-36. PMID: 7665846

[237] Andus T, Ramadori G, Heinrich PC, Knittel T, Meyer zum Büschenfelde $\mathrm{KH}$. Cultured Ito cells of rat liver express the $\alpha_{2}$-macroglobulin gene. Eur J Biochem, 1987, 168(3):641646. https://doi.org/10.1111/j.1432-1033.1987.tb13464.x PMID: 2444437

[238] Kinnman N, Housset C. Peribiliary myofibroblasts in biliary type liver fibrosis. Front Biosci, 2002, 7:d496-d503. PMID: 11815289

[239] Marra F, Pinzani M. Role of hepatic stellate cells in the pathogenesis of portal hypertension. Nefrologia, 2002, 22(Suppl 5):34-40. PMID: 12107915

[240] Rockey DC, Fouassier L, Chung JJ, Carayon A, Vallee P, Rey C, Housset C. Cellular localization of endothelin-1 and increased production in liver injury in the rat: potential for autocrine and paracrine effects on stellate cells. Hepatology, 1998, 27(2):472-480. https://doi.org/10.1002/hep.510270222 PMID: 9462646

[241] Rockey DC, Chung JJ. Inducible nitric oxide synthase in rat hepatic lipocytes and the effect of nitric oxide on lipocyte contractility. J Clin Invest, 1995, 95(3):1199-1206. https:// doi.org/10.1172/JCI117769 PMID: 7533786 PMCID: PMC 441458

[242] Gressner AM, Lahme B, Meurer SK, Gressner O, Weiskirchen R. Variable expression of cystatin $C$ in cultured trans-differentiating rat hepatic stellate cells. World J Gastroenterol, 2006, 12(5):731-738. https://doi.org/10.3748/ wjg.v12.i5.731 PMID: 16521186 PMCID: PMC4066123

[243] Stevens LA, Coresh J, Greene T, Levey AS. Assessing kidney function - measured and estimated glomerular filtration rate. N Engl J Med, 2006, 354(23):2473-2483. https://doi.org/10. 1056/NEJMra054415 PMID: 16760447

[244] Hautekeete ML, Dodeman I, Azais-Braesco V, Van den Berg K, Seynaeve C, Geerts A. Hepatic stellate cells and liver retinoid content in alcoholic liver disease in humans. Alcohol Clin Exp Res, 1998, 22(2):494-500. PMID: 9581658

[245] Okanoue T, Burbige EJ, French SW. The role of the Ito cell in perivenular and intralobular fibrosis in alcoholic hepatitis. Arch Pathol Lab Med, 1983, 107(9):459-463. PMID: 6688340

[246] Giannelli G, Antonaci S. Immunological and molecular aspects of liver fibrosis in chronic hepatitis $\mathrm{C}$ virus infection. Histo Histopathol, 2005, 20(3):939-944. https://doi.org/10.14670/ $\mathrm{HH}-20.939$ PMID: 15944944

[247] Guido M, Rugge M, Leandro G, Fiel IM, Thung SN. Hepatic stellate cell immunodetection and cirrhotic evolution of viral hepatitis in liver allografts. Hepatology, 1997, 26(2):310-314 https://doi.org/10.1002/hep.510260209 PMID: 9252139

[248] Guyot C, Lepreux S, Combe C, Doudnikoff E, BioulacSage $P$, Balabaud $C$, Desmoulière $A$. Hepatic fibrosis and cirrhosis: the (myo)fibroblastic cell subpopulations involved. Int J Biochem Cell Biol, 2006, 38(2):135-151. https://doi.org/ 10.1016/j.biocel.2005.08.021 PMID: 16257564

[249] Inuzuka S, Ueno T, Torimura T, Sata M, Abe H, Tanikawa K. Immunohistochemistry of the hepatic extracellular matrix in acute viral hepatitis. Hepatology, 1990, 12(2):249-256. https:// doi.org/10.1002/hep.1840120211 PMID: 2202635

[250] Khan MA, Poulos JE, Brunt EM, Li L, Solomon H, Britton RS Bacon BR, Di Bisceglie AM. Hepatic $\alpha$-smooth muscle actin expression in hepatitis $C$ patients before and after interferon therapy. Hepatogastroenterology, 2001, 48(37):212-215. PMID: 11268968

[251] Tomanovic NR, Boricic IV, Brasanac DC, Stojsic ZM, Delic DS, Brmbolic BJ. Activated liver stellate cells in chronic viral $C$ hepatitis: histopathological and immunohistochemical study. J Gastrointestin Liver Dis, 2009, 18(2):163-167. PMID: 19565045

[252] Zakaria S, Youssef M, Moussa M, Akl M, El-Ahwany E, ElRaziky M, Mostafa O, Helmy AH, El-Hindawi A. Value of $\alpha$-smooth muscle actin and glial fibrillary acidic protein in predicting early hepatic fibrosis in chronic hepatitis $\mathrm{C}$ virus infection. Arch Med Sci, 2010, 6(3):356-365. https://doi. org/10.5114/aoms.2010.14255 PMID: 22371771 PMCID: PMC3282512

[253] Łotowska JM, Lebensztejn DM. Immunoreactive hepatic stellate cells in biopsy material in children with chronic hepatitis $\mathrm{B}$. The first report in pediatric patients. Pol J Pathol, 2015, 66(3):224-230. https://doi.org/10.5114/pjp.2015.54955 PMID: 26619100

[254] Shiraha H, Iwamuro M, Okada H. Hepatic stellate cells in liver tumor. Adv Exp Med Biol, 2020, 1234:43-56. https://doi. org/10.1007/978-3-030-37184-5_4 PMID: 32040854

[255] Sun B, Zhang X, Cheng X, Zhang Y, Chen L, Shi L, Liu Z, Qian $\mathrm{H}$, Wu M, Yin Z. Intratumoral hepatic stellate cells as a poor prognostic marker and a new treatment target for hepatocellular carcinoma. PLoS One, 2013, 8(11):e80212. https://doi.org/10.1371/journal.pone.0080212 PMID: 24278260 PMCID: PMC3835887

[256] Thompson AI, Conroy KP, Henderson NC. Hepatic stellate cells: central modulators of hepatic carcinogenesis. BMC Gastroenterol, 2015, 15:63. https://doi.org/10.1186/s12876015-0291-5 PMID: 26013123 PMCID: PMC4445994

[257] Tahmasebi Birgani M, Carloni V. Tumor microenvironment, a paradigm in hepatocellular carcinoma progression and therapy. Int J Mol Sci, 2017, 18(2):405. https://doi.org/10. 3390/ijms18020405 PMID: 28216578 PMCID: PMC5343939

[258] Schmitt-Gräff A, Chakroun G, Gabbiani G. Modulation of perisinusoidal cell cytoskeletal features during experimental hepatic fibrosis. Virchows Arch A Pathol Anat Histopathol, 1993, 422(2):99-107. https://doi.org/10.1007/BF01607161 PMID: 8465518

[259] Resnick JM, Whitley CB, Leonard AS, Krivit W, Snover DC. Light and electron microscopic features of the liver in mucopolysaccharidosis. Hum Pathol, 1994, 25(3):276-286. https://doi.org/10.1016/046-8177(94)90200-3 PMID: 8150458

[260] Mathew J, Hines JE, James OF, Burt AD. Non-parenchymal cell responses in paracetamol (acetaminophen)-induced liver injury. J Hepatol, 1994, 20(4):537-541. https://doi.org/10.10 16/s0168-8278(05)80502-1 PMID: 8051394

[261] el Hag IA, Hashim FA, el Toum IA, Homeida M, el Kalifa M, el Hassan AM. Liver morphology and function in visceral leishmaniasis (Kala-azar). J Clin Pathol, 1994, 47(6):547551. https://doi.org/10.1136/jcp.47.6.547 PMID: 8063939 PMCID: PMC494751

[262] Clark AM, Ma B, Taylor DL, Griffith L, Wells A. Liver metastases: microenvironments and ex-vivo models. Exp Biol Med (Maywood), 2016, 241(15):1639-1652. https://doi.org/ 10.1177/1535370216658144 PMID: 27390264 PMCID: PMC4999624

[263] Ishibashi H, Nakamura M, Komori A, Migita K, Shimoda S. Liver architecture, cell function, and disease. Semin Immunopathol, 2009, 31(3):399-409. https://doi.org/10.1007/s0028 1-009-0155-6 PMID: 19468732

[264] Kmieć Z. Cooperation of liver cells in health and disease. Adv Anat Embryol Cell Biol, 2001, 161:III-XIII, 1-151. https:// doi.org/10.1007/978-3-642-56553-3 PMID: 11729749

[265] Bataller R, Brenner DA. Liver fibrosis. J Clin Invest, 2005, 115(2):209-218. https://doi.org/10.1172/JCI24282 PMID: 15690074 PMCID: PMC546435

[266] Anstee QM, Reeves HL, Kotsiliti E, Govaere O, Heikenwalder M. From NASH to HCC: current concepts and future challenges. Nat Rev Gastroenterol Hepatol, 2019, 16(7):411-428. https:// doi.org/10.1038/s41575-019-0145-7 PMID: 31028350

[267] Hernandez-Gea V, Friedman SL. Pathogenesis of liver fibrosis. Annu Rev Pathol, 2011, 6:425-456. https://doi.org/10.1146/ annurev-pathol-011110-130246 PMID: 21073339

[268] Dewidar B, Meyer C, Dooley S, Meindl-Beinker N. TGF- $\beta$ in hepatic stellate cell activation and liver fibrogenesis updated 2019. Cells, 2019, 8(11):1419. https://doi.org/10. 3390/cells8111419 PMID: 31718044 PMCID: PMC6912224

[269] Ni Y, Li JM, Liu MK, Zhang TT, Wang DP, Zhou WH, Hu LZ, Lv WL. Pathological process of liver sinusoidal endothelial 
cells in liver diseases. World J Gastroenterol, 2017, 23(43): 7666-7677. https://doi.org/10.3748/wjg.v23.i43.7666 PMID: 29209108 PMCID: PMC5703927

[270] Fattovich G, Stroffolini T, Zagni I, Donato F. Hepatocellular carcinoma in cirrhosis: incidence and risk factors. Gastroenterology, 2004, 127(5 Suppl 1):S35-S50. https://doi.org/ 10.1053/j.gastro.2004.09.014 PMID: 15508101

[271] Wang BB, Cheng JY, Gao HH, Zhang Y, Chen ZN, Bian H. Hepatic stellate cells in inflammation-fibrosis-carcinoma axis Anat Rec (Hoboken), 2010, 293(9):1492-1496. https://doi.org/ 10.1002/ar.21173 PMID: 20652939

[272] Kostallari E, Shah VH. Angiocrine signaling in the hepatic sinusoids in health and disease. Am J Physiol Gastrointest Liver Physiol, 2016, 311(2):G246-G251. https://doi.org/10. 1152/ajpgi.00118.2016 PMID: 27288423 PMCID: PMC 5007289

[273] Dou C, Liu Z, Tu K, Zhang H, Chen C, Yaqoob U, Wang Y, Wen J, van Deursen J, Sicard D, Tschumperlin D, Zou H, Huang WC, Urrutia R, Shah VH, Kang N. P300 acetyltransferase mediates stiffness-induced activation of hepatic stellate cells into tumor-promoting myofibroblasts. Gastroenterology, 2018, 154(8):2209-2221.e14. https://doi.org/10. 1053/j.gastro.2018.02.015 PMID: 29454793 PMCID: PMC 6039101

[274] Bilzer M, Roggel F, Gerbes AL. Role of Kupffer cells in host defense and liver disease. Liver Int, 2006, 26(10):11751186. https://doi.org/10.1111/j.1478-3231.2006.01342.x PMID 17105582

[275] Canbay A, Higuchi H, Bronk SF, Taniai M, Sebo TJ, Gores GJ. Fas enhances fibrogenesis in the bile duct ligated mouse: a link between apoptosis and fibrosis. Gastroenterology, 2002, 123(4):1323-1330. https://doi.org/10.1053/gast.2002. 35953 PMID: 12360492

[276] Canbay A, Taimr P, Torok N, Higuchi H, Friedman S, Gores GJ. Apoptotic body engulfment by a human stellate cell line is profibrogenic. Lab Invest, 2003, 83(5):655-663. https://doi.org/10.1097/01.lab.0000069036.63405.5c PMID: 12746475

[277] Kostallari E, Hirsova P, Prasnicka A, Verma VK, Yaqoob U, Wongjarupong N, Roberts LR, Shah VH. Hepatic stellate cell-derived platelet-derived growth factor receptor-alphaenriched extracellular vesicles promote liver fibrosis in mice through SHP2. Hepatology, 2018, 68(1):333-348. https://doi. org/10.1002/hep.29803 PMID: 29360139 PMCID: PMC 6033667

[278] Lan T, Li C, Yang G, Sun Y, Zhuang L, Ou Y, Li H, Wang G, Kisseleva T, Brenner D, Guo J. Sphingosine kinase 1 promotes liver fibrosis by preventing miR-19b-3p-mediated inhibition of CCR2. Hepatology, 2018, 68(3):1070-1086. https://doi.org/10.1002/hep.29885 PMID: 29572892 PMCID: PMC6174945

[279] Marra F, Romanelli RG, Giannini C, Failli P, Pastacaldi S, Arrighi MC, Pinzani M, Laffi G, Montalto P, Gentilini P. Monocyte chemotactic protein-1 as a chemoattractant for human hepatic stellate cells. Hepatology, 1999, 29(1):140148. https://doi.org/10.1002/hep.510290107 PMID: 9862860

[280] Seki E, de Minicis S, Inokuchi S, Taura K, Miyai K, van Rooijen N, Schwabe RF, Brenner DA. CCR2 promotes hepatic fibrosis in mice. Hepatology, 2009, 50(1):185-197. https://doi.org/10.1002/hep.22952 PMID: 19441102 PMCID: PMC2705470

[281] Jiang JX, Venugopal S, Serizawa N, Chen X, Scott F, Li Y, Adamson R, Devaraj S, Shah V, Gershwin ME, Friedman SL, Török NJ. Reduced nicotinamide adenine dinucleotide phosphate oxidase 2 plays a key role in stellate cell activation and liver fibrogenesis in vivo. Gastroenterology, 2010, 139(4):1375-1384. https://doi.org/10.1053/j.gastro.2010.05 074 PMID: 20685364 PMCID: PMC2949521

[282] Kordes C, Häussinger D. Hepatic stem cell niches. J Clin Invest, 2013, 123(5):1874-1880. https://doi.org/10.1172/ JCI66027 PMID: 23635785 PMCID: PMC3638908

[283] Wang R, Ding Q, Yaqoob U, de Assuncao TM, Verma VK, Hirsova P, Cao S, Mukhopadhyay D, Huebert RC, Shah VH. Exosome adherence and internalization by hepatic stellate cells triggers sphingosine 1-phosphate-dependent migration. J Biol Chem, 2015, 290(52):30684-30696. https://doi.org/ 10.1074/jbc.M115.671735 PMID: 26534962 PMCID: PMC 4692200
[284] Ding BS, Cao Z, Lis R, Nolan DJ, Guo P, Simons M, Penfold ME, Shido K, Rabbany SY, Rafii S. Divergent angiocrine signals from vascular niche balance liver regeneration and fibrosis. Nature, 2014, 505(7481):97-102. https://doi.org/ 10.1038/nature12681 PMID: 24256728 PMCID: PMC4142699

[285] Li JT, Liao ZX, Ping J, Xu D, Wang H. Molecular mechanism of hepatic stellate cell activation and antifibrotic therapeutic strategies. J Gastroenterol, 2008, 43(6):419-428. https:// doi.org/10.1007/s00535-008-2180-y PMID: 18600385

[286] Drinane MC, Yaqoob U, Yu H, Luo F, Greuter T, Arab JP, Kostallari E, Verma VK, Maiers J, De Assuncao TM, Simons M, Mukhopadhyay D, Kisseleva T, Brenner DA, Urrutia R, Lomberk G, Gao Y, Ligresti G, Tschumperlin DJ, Revzin A, Cao S, Shah VH. Synectin promotes fibrogenesis by regulating PDGFR isoforms through distinct mechanisms. JCl Insight, 2017, 2(24):e92821. https://doi.org/10.1172/jci. insight.92821 PMID: 29263300 PMCID: PMC5752303

[287] Ohata M, Lin M, Satre M, Tsukamoto H. Diminished retinoic acid signaling in hepatic stellate cells in cholestatic liver fibrosis. Am J Physiol, 1997, 272(3 Pt 1):G589-G596. https:// doi.org/10.1152/ajpgi.1997.272.3.G589 PMID: 9124579

[288] Chen M, Liu J, Yang W, Ling W. Lipopolysaccharide mediates hepatic stellate cell activation by regulating autophagy and retinoic acid signaling. Autophagy, 2017, 13(11):18131827. https://doi.org/10.1080/15548627.2017.1356550 PMID: 29160747 PMCID: PMC5788469

[289] Dangi A, Huang C, Tandon A, Stolz D, Wu T, Gandhi CR. Endotoxin-stimulated rat hepatic stellate cells induce autophagy in hepatocytes as a survival mechanism. J Cell Physiol, 2016, 231(1):94-105. https://doi.org/10.1002/jcp. 25055 PMID: 26031389 PMCID: PMC5679025

[290] Das A, Shergill U, Thakur L, Sinha S, Urrutia R, Mukhopadhyay D, Shah VH. Ephrin B2/EphB4 pathway in hepatic stellate cells stimulates Erk-dependent VEGF production and sinusoidal endothelial cell recruitment. Am J Physiol Gastrointest Liver Physiol, 2010, 298(6):G908-G915. https:// doi.org/10.1152/ajpgi.00510.2009 PMID: 20338920 PMCID: PMC3695393

[291] Shearer AM, Rana R, Austin K, Baleja JD, Nguyen N, Bohm A Covic $L$, Kuliopulos A. Targeting liver fibrosis with a cellpenetrating protease-activated receptor-2 (PAR2) pepducin. J Biol Chem, 2016, 291(44):23188-23198. https://doi.org/ 10.1074/jbc.M116.732743 PMID: 27613872 PMCID: PMC 5087736

[292] Guvendiren M, Perepelyuk M, Wells RG, Burdick JA. Hydrogels with differential and patterned mechanics to study stiffnessmediated myofibroblastic differentiation of hepatic stellate cells. J Mech Behav Biomed Mater, 2014, 38:198-208. https://doi.org/10.1016/j.jmbbm.2013.11.008 PMID: 24361340 PMCID: PMC4045659

[293] Vallet SD, Ricard-Blum S. Lysyl oxidases: from enzyme activity to extracellular matrix cross-links. Essays Biochem, 2019, 63(3):349-364. https://doi.org/10.1042/EBC20180050 PMID: 31488698

[294] Perepelyuk M, Terajima M, Wang AY, Georges PC, Janmey PA, Yamauchi M, Wells RG. Hepatic stellate cells and portal fibroblasts are the major cellular sources of collagens and lysyl oxidases in normal liver and early after injury. Am J Physiol Gastrointest Liver Physiol, 2013, 304(6):G605-G614. https://doi.org/10.1152/ajpgi.00222.2012 PMID: 23328207 PMCID: PMC3602686

[295] Grenard P, Bresson-Hadni S, El Alaoui S, Chevallier M, Vuitton DA, Ricard-Blum S. Transglutaminase-mediated crosslinking is involved in the stabilization of extracellular matrix in human liver fibrosis. J Hepatol, 2001, 35(3):367-375. https:// doi.org/10.1016/s0168-8278(01)00135-0 PMID: 11592598

[296] Bonnans C, Chou J, Werb Z. Remodelling the extracellular matrix in development and disease. Nat Rev Mol Cell Biol, 2014, 15(12):786-801. https://doi.org/10.1038/nrm3904 PMID: 25415508 PMCID: PMC4316204

[297] Roderburg C, Urban GW, Bettermann K, Vucur M, Zimmermann H, Schmidt S, Janssen J, Koppe C, Knolle P, Castoldi M, Tacke F, Trautwein C, Luedde T. Micro-RNA profiling reveals a role for miR-29 in human and murine liver fibrosis. Hepatology, 2011, 53(1):209-218. https://doi.org/ 10.1002/hep.23922 PMID: 20890893

[298] Murakami Y, Kawada N. MicroRNAs in hepatic pathophysiology. Hepatol Res, 2017, 47(1):60-69. https://doi.org/10. 1111/hepr.12730 PMID: 27101519 
[299] Coll M, El Taghdouini A, Perea L, Mannaerts I, Vila-Casadesús M, Blaya D, Rodrigo-Torres D, Affò S, Morales-lbanez O Graupera I, Lozano JJ, Najimi M, Sokal E, Lambrecht J, Ginès $P$, van Grunsven LA, Sancho-Bru $P$. Integrative miRNA and gene expression profiling analysis of human quiescent hepatic stellate cells. Sci Rep, 2015, 5(1):11549. https://doi.org/10.1038/srep11549 PMID: 26096707 PMCID: PMC4476106

[300] McDaniel K, Huang L, Sato K, Wu N, Annable T, Zhou T, Ramos-Lorenzo S, Wan Y, Huang Q, Francis H, Glaser S, Tsukamoto H, Alpini G, Meng F. The let-7/Lin28 axis regulates activation of hepatic stellate cells in alcoholic liver injury. J Biol Chem, 2017, 292(27):11336-11347. https://doi.org/10.1074/jbc.M116.773291 PMID: 28536261 PMCID: PMC5500799

[301] Ji J, Zhang J, Huang G, Qian J, Wang X, Mei S. Overexpressed microRNA-27a and 27b influence fat accumulation and cell proliferation during rat hepatic stellate cell activation FEBS Lett, 2009, 583(4):759-766. https://doi.org/10.1016/ j.febslet.2009.01.034 PMID: 19185571

[302] Hellemans K, Verbuyst P, Quartier E, Schuit F, Rombouts K, Chandraratna RAS, Schuppan D, Geerts A. Differential modulation of rat hepatic stellate phenotype by natural and synthetic retinoids. Hepatology, 2004, 39(1):97-108. https:// doi.org/10.1002/hep.20015 PMID: 14752828

[303] Ringelhan M, McKeating JA, Protzer U. Viral hepatitis and liver cancer. Philos Trans R Soc B Biol Sci, 2017 372(1732):20160274. https://doi.org/10.1098/rstb.2016.0274 PMID: 28893941 PMCID: PMC5597741

[304] Friedman A, Siewe N. Chronic hepatitis B virus and liver fibrosis: a mathematical model. PLoS One, 2018, 13(4): e0195037. https://doi.org/10.1371/journal.pone.0195037 PMID: 29634771 PMCID: PMC5892900

[305] Bai Q, An J, Wu X, You H, Ma H, Liu T, Gao N, Jia J. HBV promotes the proliferation of hepatic stellate cells via the PDGF-B/PDGFR- $\beta$ signaling pathway in vitro. Int J Mol Med, 2012, 30(6):1443-1450. https://doi.org/10.3892/ijmm.2012. 1148 PMID: 23042547

[306] Zan Y, Zhang Y, Tien P. Hepatitis B virus e antigen induces activation of rat hepatic stellate cells. Biochem Biophys Res Commun, 2013, 435(3):391-396. https://doi.org/10.1016/j. bbrc.2013.04.098 PMID: 23665329

[307] Chen HY, Chen ZX, Huang RF, Lin N, Wang XZ. Hepatitis B virus $X$ protein activates human hepatic stellate cells through upregulating TGF $\beta 1$. Genet Mol Res, 2014, 13(4):8645-8656. https://doi.org/10.4238/2014.October.27.4 PMID: 25366754

[308] Guo GH, Tan DM, Zhu PA, Liu F. Hepatitis B virus X protein promotes proliferation and upregulates TGF-beta1 and CTGF in human hepatic stellate cell line, LX-2. Hepatobiliary Pancreat Dis Int, 2009, 8(1):59-64. PMID: 19208517

[309] Tan Z, Qian X, Jiang R, Liu Q, Wang Y, Chen C, Wang X Ryffel B, Sun B. IL-17A plays a critical role in the pathogenesis of liver fibrosis through hepatic stellate cell activation J Immunol, 2013, 191(4):1835-1844. https://doi.org/10.4049/ jimmunol.1203013 PMID: 23842754

[310] Wang Q, Zhou J, Zhang B, Tian Z, Tang J, Zheng $Y$, Huang $Z$, Tian $Y$, Jia $Z$, Tang $Y$, van Velkinburgh JC, Mao $Q$, Bian $X$, Ping $Y$, Ni B, Wu Y. Hepatitis B virus induces IL-23 production in antigen presenting cells and causes live damage via the IL-23/IL-17 axis. PLoS Pathog, 2013, 9(6): e1003410. https://doi.org/10.1371/journal.ppat.1003410 PMID: 23825942 PMCID: PMC3694858

[311] Wu LY, Liu S, Liu Y, Guo C, Li H, Li W, Jin X, Zhang K, Zhao $\mathrm{P}$, Wei L, Zhao J. Up-regulation of interleukin-22 mediates liver fibrosis via activating hepatic stellate cells in patients with hepatitis C. Clin Immunol, 2015, 158(1):77-87. https://doi.org/10.1016/j.clim.2015.03.003 PMID: 25771172

[312] Mengshol JA, Golden-Mason L, Rosen HR. Mechanisms of disease: HCV-induced liver injury. Nat Clin Pract Gastroenterol Hepatol, 2007, 4(11):622-634. https://doi.org/10. 1038/ncpgasthep0961 PMID: 17978819

[313] Spengler U, Nattermann J. Immunopathogenesis in hepatitis C virus cirrhosis. Clin Sci (Lond), 2007, 112(3):141-155. https://doi.org/10.1042/CS20060171 PMID: 17199558

[314] Brenner DA, Waterboer T, Choi SK, Lindquist JN, Stefanovic B Burchardt E, Yamauchi M, Gillan A, Rippe RA. New aspects of hepatic fibrosis. J Hepatol, 2000, 32(1 Suppl):32-38. https:// doi.org/10.1016/s0168-8278(00)80413-4 PMID: 10728792
[315] Tsukada S, Parsons CJ, Rippe RA. Mechanisms of liver fibrosis. Clin Chim Acta, 2006, 364(1-2):33-60. https://doi. org/10.1016/j.cca.2005.06.014 PMID: 16139830

[316] Wang Y, Li J, Wang X, Sang M, Ho W. Hepatic stellate cells, liver innate immunity, and hepatitis $C$ virus. J Gastroentero Hepatol, 2013, 28(Suppl 1):112-115. https://doi.org/10.1111/ jgh.12023 PMID: 23855305 PMCID: PMC3937257

[317] Mazzocca A, Sciammetta SC, Carloni V, Cosmi L, Annunziato F, Harada T, Abrignani S, Pinzani M. Binding of hepatitis $C$ virus envelope protein E2 to CD81 up-regulates matrix metalloproteinase-2 in human hepatic stellate cells. J Biol Chem, 2005, 280(12):11329-11339. https://doi.org/ 10.1074/jbc.M410161200 PMID: 15611113

[318] Bataller R, Paik YH, Lindquist JN, Lemasters JJ, Brenner DA Hepatitis $C$ virus core and nonstructural proteins induce fibrogenic effects in hepatic stellate cells. Gastroenterology, 2004, 126(2):529-540. https://doi.org/10.1053/j.gastro.2003. 11.018 PMID: 14762790

[319] Wang B, Trippler M, Pei R, Lu M, Broering R, Gerken G, Schlaak JF. Toll-like receptor activated human and murine hepatic stellate cells are potent regulators of hepatitis $C$ virus replication. J Hepatol, 2009, 51(6):1037-1045. https:// doi.org/10.1016/j.jhep.2009.06.020 PMID: 19716616

[320] Shahin K, Hosseini SY, Jamali H, Karimi MH, Azarpira N, Zeraatian M. The enhancing impact of amino termini of hepatitis $C$ virus core protein on activation of hepatic stellate cells. Gastroenterol Hepatol Bed Bench, 2020, 13(1):57-63. PMID: 32190226 PMCID: PMC7069533

[321] Schulze-Krebs A, Preimel D, Popov Y, Bartenschlager R, Lohmann V, Pinzani M, Schuppan D. Hepatitis C virusreplicating hepatocytes induce fibrogenic activation of hepatic stellate cells. Gastroenterology, 2005, 129(1):246-258. https:// doi.org/10.1053/j.gastro.2005.03.089 PMID: 16012951

[322] Jiang JX, Mikami K, Shah VH, Torok NJ. Leptin induces phagocytosis of apoptotic bodies by hepatic stellate cells via a Rho guanosine triphosphatase-dependent mechanism. Hepatology, 2008, 48(5):1497-1505. https://doi.org/10.1002/ hep.22515 PMID: 18925608 PMCID: PMC2596754

[323] Nishitsuji H, Funami K, Shimizu Y, Ujino S, Sugiyama K, Seya T, Takaku H, Shimotohno K. Hepatitis $C$ virus infection induces inflammatory cytokines and chemokines mediated by the cross talk between hepatocytes and stellate cells. J Virol, 2013, 87(14):8169-8178. https://doi.org/10.1128/ JVI.00974-13 PMID: 23678168 PMCID: PMC3700210

[324] Cheng JC, Tseng CP, Liao MH, Peng CY, Yu JS, Chuang PH, Huang JT, Chen JJW. Activation of hepatic stellate cells by the ubiquitin C-terminal hydrolase 1 protein secreted from hepatitis C virus-infected hepatocytes. Sci Rep, 2017 , 7(1):4448. https://doi.org/10.1038/s41598-017-04259-7 PMID: 28667290 PMCID: PMC5493679

[325] Khan F, Peltekian KM, Peterson TC. Effect of interferonalpha, ribavirin, pentoxifylline, and interleukin-18 antibody on hepatitis $\mathrm{C}$ sera-stimulated hepatic stellate cell proliferation. J Interferon Cytokine Res, 2008, 28(11):643-651. https:// doi.org/10.1089/jir.2007.0123 PMID: 18844579

[326] Gawrieh S, Papouchado BG, Burgart LJ, Kobayashi S, Charlton MR, Gores GJ. Early hepatic stellate cell activation predicts severe hepatitis $C$ recurrence after liver transplantation. Liver Transpl, 2005, 11(10):1207-1213. https://doi.org/ 10.1002/It.20455 PMID: 16184568

[327] Chu CM, Shyu WC, Liaw YF. Comparative studies on expression of alpha-smooth muscle actin in hepatic stellate cells in chronic hepatitis B and C. Dig Dis Sci, 2008, 53(5): 1364-1369. https://doi.org/10.1007/s10620-007-9997-8 PMID: 17934809

[328] Baroni GS, Pastorelli A, Manzin A, Benedetti A, Marucci L, Solforosi L, Di Sario A, Brunelli E, Orlandi F, Clementi M, Macarri G. Hepatic stellate cell activation and liver fibrosis are associated with necroinflammatory injury and Th1-like response in chronic hepatitis C. Liver, 1999, 19(3):212-219. https://doi.org/10.1111/j.1478-3231.1999.tb00038.x PMID: 10395041

[329] Clouston AD, Jonsson JR, Purdie DM, Macdonald GA, Pandeya N, Shorthouse C, Powell EE. Steatosis and chronic hepatitis $\mathrm{C}$ : analysis of fibrosis and stellate cell activation. J Hepatol, 2001, 34(2):314-320. https://doi.org/10.1016/ s0168-8278(00)00096-9 PMID: 11281562

[330] Săndulescu L, Rogoveanu I, Ciurea T, Comănescu MV, Streba CT, Ionescu AG, Oproaica A, Ene M. Immunohistochemical study of stellate cells in patients with chronic viral 
hepatitis C genotype 1. Rom J Morphol Embryol, 2011, 52(1):137-143. PMID: 21424045

[331] Ionescu AG, Streba LAM, Vere CC, Ciurea ME, Streba CT, Ionescu M, Comănescu M, Irimia E, Rogoveanu O. Histopathological and immunohistochemical study of hepatic stellate cells in patients with viral $\mathrm{C}$ chronic liver disease Rom J Morphol Embryol, 2013, 54(4):983-991. PMID: 24398994

[332] Hess KR, Varadhachary GR, Taylor SH, Wei W, Raber MN Lenzi R, Abbruzzese JL. Metastatic patterns in adenocarcinoma. Cancer, 2006, 106(7):1624-1633. https://doi.org/ 10.1002/cncr.21778 PMID: 16518827

[333] Jaques DP, Coit DG, Casper ES, Brennan MF. Hepatic metastases from soft-tissue sarcoma. Ann Surg, 1995 221(4):392-397. https://doi.org/10.1097/00000658-1995040 00-00010 PMID: 7726675 PMCID: PMC1234589

[334] Amankwah EK, Conley AP, Reed DR. Epidemiology and therapies for metastatic sarcoma. Clin Epidemiol, 2013, 5:147-162. https://doi.org/10.2147/CLEP.S28390 PMID: 23700373 PMCID: PMC3660127

[335] Ryu SW, Saw R, Scolyer RA, Crawford M, Thompson JF, Sandroussi C. Liver resection for metastatic melanoma: equivalent survival for cutaneous and ocular primaries. J Surg Oncol, 2013, 108(2):129-135. https://doi.org/10. 1002/jso.2336 PMID: 23813600

[336] Bray F, Ferlay J, Soerjomataram I, Siegel RL, Torre LA Jemal A. Global cancer statistics 2018: GLOBOCAN estimates of incidence and mortality worldwide for 36 cancers in 185 countries. CA Cancer J Clin, 2018, 68(6):394-424. https:// doi.org/10.3322/caa.c.21492 PMID: 30207593

[337] Ananthakrishnan A, Gogineni V, Saeian K. Epidemiology of primary and secondary liver cancers. Semin Intervent Radiol, 2006, 23(1):47-63. https://doi.org/10.1055/s-2006-939841 PMID: 21326720 PMCID: PMC3036307

[338] Chen F, Zhuang X, Lin L, Yu P, Wang Y, Shi Y, Hu G, Sun Y. New horizons in tumor microenvironment biology: challenges and opportunities. BMC Med, 2015, 13:45. https://doi.org/ 10.1186/s12916-015-0278-7 PMID: 25857315 PMCID: PMC4350882

[339] Shimoda M, Mellody KT, Orimo A. Carcinoma-associated fibroblasts are a rate-limiting determinant for tumour progression. Semin Cell Dev Biol, 2010, 21(1):19-25. https:// doi.org/10.1016/j.semcdb.2009.10.002 PMID: 19857592 PMCID: PMC2828545

[340] Singh SR, Rameshwar P, Siegel P. Targeting tumor microenvironment in cancer therapy. Cancer Lett, 2016, 380(1): 203-204. https://doi.org/10.1016/j.canlet.2016.04.009 PMID: 27060765

[341] Yang JD, Nakamura I, Roberts LR. The tumor microenvironment in hepatocellular carcinoma: current status and therapeutic targets. Semin Cancer Biol, 2011, 21(1):35-43. https://doi.org/10.1016/j.semcancer.2010.10.007 PMID: 20946957 PMCID: PMC3050428

[342] Bertuccio P, Turati F, Carioli G, Rodriguez T, La Vecchia C Malvezzi M, Negri E. Global trends and predictions in hepatocellular carcinoma mortality. J Hepatol, 2017, 67(2): 302-309. https://doi.org/10.1016/j.jhep.2017.03.011 PMID: 28336466

[343] Llovet JM, Zucman-Rossi J, Pikarsky E, Sangro B, Schwartz M, Sherman M, Gores G. Hepatocellular carcinoma. Nat Rev Dis Primers, 2016, 2:16018. https://doi.org/10.1038/nrdp. 2016.18 PMID: 27158749

[344] Rombouts K, Carloni V. The fibrotic microenvironment as a heterogeneity facet of hepatocellular carcinoma. Fibrogenesis Tissue Repair, 2013, 6(1):17. https://doi.org/10.1186/17551536-6-17 PMID: 24350713 PMCID: PMC3849063

[345] Park YN, Yang CP, Cubukcu O, Thung SN, Theise ND. Hepatic stellate cell activation in dysplastic nodules: evidence for an alternate hypothesis concerning human hepatocarcinogenesis. Liver, 1997, 17(6):271-274. https://doi.org/ 10.1111/j.1600-0676.1997.tb01031.x PMID: 9455731

[346] Schrader J, Gordon-Walker TT, Aucott RL, van Deemter M, Quaas A, Walsh S, Benten D, Forbes SJ, Wells RG, Iredale JP. Matrix stiffness modulates proliferation, chemotherapeutic response, and dormancy in hepatocellular carcinoma cells. Hepatology, 2011, 53(4):1192-1205. https://doi.org/10.1002/ hep.24108 PMID: 21442631 PMCID: PMC3076070

[347] Legate KR, Wickström SA, Fässler R. Genetic and cell biological analysis of integrin outside-in signaling. Genes Dev, 2009, 23(4):397-418. https://doi.org/10.1101/gad.175 8709 PMID: 19240129
[348] Desgrosellier JS, Cheresh DA. Integrins in cancer: biological implications and therapeutic opportunities. Nat Rev Cancer, 2010, 10(1):9-22. https://doi.org/10.1038/nrc2748 PMID: 20029421 PMCID: PMC4383089

[349] Reif S, Lang A, Lindquist JN, Yata Y, Gabele E, Scanga A, Brenner DA, Rippe RA. The role of focal adhesion kinasephosphatidylinositol 3-kinase-akt signaling in hepatic stellate cell proliferation and type I collagen expression. J Biol Chem, 2003, 278(10):8083-8090. https://doi.org/10.1074/jbc.M21 2927200 PMID: 12502711

[350] Dong Y, Xie X, Wang Z, Hu C, Zheng Q, Wang Y, Chen R, Xue T, Chen J, Gao D, Wu W, Ren Z, Cui J. Increasing matrix stiffness upregulates vascular endothelial growth factor expression in hepatocellular carcinoma cells mediated by integrin $\beta 1$. Biochem Biophys Res Commun, 2014, 444(3):427-432. https://doi.org/10.1016/j.bbrc.2014.01.079 PMID: 24472554

[351] Lee SK, Kim MH, Cheong JY, Cho SW, Yang SJ, Kwack K. Integrin alpha $\mathrm{V}$ polymorphisms and haplotypes in a Korean population are associated with susceptibility to chronic hepatitis and hepatocellular carcinoma. Liver Int, 2009, 29(2):187-195. https://doi.org/10.1111/j.1478-3231.2008.01 843.x PMID: 18694400

[352] Lai KKY, Shang S, Lohia N, Booth GC, Masse DJ, Fausto N, Campbell JS, Beretta L. Extracellular matrix dynamics in hepatocarcinogenesis: a comparative proteomics study of PDGFC transgenic and Pten null mouse models. PLoS Genet, 2011, 7(6):e1002147. https://doi.org/10.1371/journal. pgen.1002147 PMID: 21731504 PMCID: PMC3121762

[353] Jung CW, Song TJ, Lee KO, Choi SB, Kim WB, Suh SO, Kim YC, Choi SY. Characterization of hepatocellular carcinoma cell lines based on cell adhesion molecules. Int J Mol Med, 2012, 29(6):1158-1164. https://doi.org/10.3892/ijmm.2012. 951 PMID: 22447134

[354] Zhao G, Cui J, Qin Q, Zhang J, Liu L, Deng S, Wu C, Yang M, Li S, Wang C. Mechanical stiffness of liver tissues in relation to integrin $\beta 1$ expression may influence the development of hepatic cirrhosis and hepatocellular carcinoma. J Surg Oncol, 2010, 102(5):482-489. https://doi.org/10.1002/jso.2 1613 PMID: 20872952

[355] Yang C, Zeisberg M, Lively JC, Nyberg P, Afdhal N, Kalluri R. Integrin alpha1beta1 and alpha2beta1 are the key regulators of hepatocarcinoma cell invasion across the fibrotic matrix microenvironment. Cancer Res, 2003, 63(23):8312-8317. PMID: 14678990

[356] Fu BH, Wu ZZ, Qin J. Effects of integrin $\alpha 6 \beta 1$ on migration of hepatocellular carcinoma cells. Mol Biol Rep, 2011, 38(5): 3271-3276. https://doi.org/10.1007/s11033-010-0308-7 PMID: 21359644

[357] Mizuno H, Ogura M, Saito Y, Sekine W, Sano R, Gotou T, Oku T, Itoh S, Katabami K, Tsuji T. Changes in adhesive and migratory characteristics of hepatocellular carcinoma (HCC) cells induced by expression of alpha3beta1 integrin. Biochim Biophys Acta, 2008, 1780(3):564-570. https://doi.org/ 10.1016/j.bbagen.2007.09.007 PMID: 17997226

[358] Ke AW, Shi GM, Zhou J, Huang XY, Shi YH, Ding ZB, Wang XY, Devbhandari RP, Fan J. CD151 amplifies signaling by integrin $\alpha 6 \beta 1$ to $\mathrm{PI} 3 \mathrm{~K}$ and induces the epithelialmesenchymal transition in HCC cells. Gastroenterology, 2011, 140(5):1629-1641.e15. https://doi.org/10.1053/j.gastro. 2011.02.008 PMID: 21320503

[359] Azzariti A, Mancarella S, Porcelli L, Quatrale AE, Caligiuri A, Lupo L, Dituri F, Giannelli G. Hepatic stellate cells induce hepatocellular carcinoma cell resistance to sorafenib through the laminin-332/a3 integrin axis recovery of focal adhesion kinase ubiquitination. Hepatology, 2016, 64(6):2103-2117. https://doi.org/10.1002/hep.28835 PMID: 27639064

[360] Yaqoob U, Cao S, Shergill U, Jagavelu K, Geng Z, Yin M, de Assuncao TM, Cao Y, Szabolcs A, Thorgeirsson S, Schwartz M, Yang JD, Ehman R, Roberts L, Mukhopadhyay D, Shah VH. Neuropilin-1 stimulates tumor growth by increasing fibronectin fibril assembly in the tumor microenvironment. Cancer Res, 2012, 72(16):4047-4059. https://doi.org/10. 1158/0008-5472.CAN-11-3907 PMID: 22738912 PMCID: PMC3421041

[361] Fransvea E, Mazzocca A, Antonaci S, Giannelli G. Targeting transforming growth factor (TGF)-betaRI inhibits activation of beta1 integrin and blocks vascular invasion in hepatocellular carcinoma. Hepatology, 2009, 49(3):839-850. https://doi.org/ 10.1002/hep.22731 PMID: 19115199 
[362] Matsuzaki K. Smad phosphoisoform signals in acute and chronic liver injury: similarities and differences between epithelial and mesenchymal cells. Cell Tissue Res, 2012 347(1):225-243. https://doi.org/10.1007/s00441-011-1178-6 PMID: 21626291 PMCID: PMC3250618

[363] Hayashida T. Integrins modulate cellular fibrogenesis at multiple levels; regulation of TGF- $\beta$ signaling. Endocr Metab Immune Disord Drug Targets, 2010, 10(4):302-319. https:// doi.org/10.2174/1871530311006040302 PMID: 20925652

[364] Okabe H, Beppu T, Hayashi H, Horino K, Masuda T, Komori H, Ishikawa S, Watanabe M, Takamori H, lyama $\mathrm{K}$ Baba $\mathrm{H}$. Hepatic stellate cells may relate to progression of intrahepatic cholangiocarcinoma. Ann Surg Oncol, 2009 16(9):2555-2564. https://doi.org/10.1245/s10434-009-0568-4 PMID: 19548033

[365] Amann T, Bataille F, Spruss T, Mühlbauer M, Gäbele E, Schölmerich J, Kiefer P, Bosserhoff AK, Hellerbrand C Activated hepatic stellate cells promote tumorigenicity of hepatocellular carcinoma. Cancer Sci, 2009, 100(4):646653. https://doi.org/10.1111/j.1349-7006.2009.01087.x PMID: 19175606

[366] Zhao W, Zhang L, Yin Z, Su W, Ren G, Zhou C, You J, Fan J, Wang X. Activated hepatic stellate cells promote hepatocellular carcinoma development in immunocompetent mice. Int J Cancer, 2011, 129(11):2651-2661. https://doi.org/ 10.1002/ijc.25920 PMID: 21213212

[367] Kang N, Gores GJ, Shah VH. Hepatic stellate cells: partners in crime for liver metastases? Hepatology, 2011, 54(2):707713. https://doi.org/10.1002/hep.24384 PMID: 21520207 PMCID: PMC3145026

[368] Mogler C, König C, Wieland M, Runge A, Besemfelder E, Komljenovic D, Longerich T, Schirmacher P, Augustin HG. Hepatic stellate cells limit hepatocellular carcinoma progression through the orphan receptor endosialin. EMBO Mol Med, 2017, 9(6):741-749. https://doi.org/10.15252/emmm.2016 07222 PMID: 28373218 PMCID: PMC5452049

[369] Carloni V, Luong TV, Rombouts K. Hepatic stellate cells and extracellular matrix in hepatocellular carcinoma: more complicated than ever. Liver Int, 2014, 34(6):834-843. https:// doi.org/10.1111/liv.12465 PMID: 24397349

[370] Coulouarn C, Corlu A, Glaise D, Guénon I, Thorgeirsson SS, Clément B. Hepatocyte-stellate cell cross-talk in the liver engenders a permissive inflammatory microenvironment that drives progression in hepatocellular carcinoma. Cancer Res 2012, 72(10):2533-2542. https://doi.org/10.1158/0008-547 2.CAN-11-3317 PMID: 22419664 PMCID: PMC3498759

[371] Fausto N. Mouse liver tumorigenesis: models, mechanisms, and relevance to human disease. Semin Liver Dis, 1999 , 19(3):243-252. https://doi.org/10.1055/s-2007-1007114 PMID 10518304

[372] Bedossa P, Peltier E, Terris B, Franco D, Poynard T. Transforming growth factor-beta 1 (TGF-beta 1) and TGFbeta 1 receptors in normal, cirrhotic, and neoplastic human livers. Hepatology, 1995, 21(3):760-766. https://doi.org/10. 1002/hep.1840210325 PMID: 7875675

[373] Shirai Y, Kawata S, Tamura S, Ito N, Tsushima H, Takaishi K, Kiso S, Matsuzawa Y. Plasma transforming growth factorbeta 1 in patients with hepatocellular carcinoma. Comparison with chronic liver diseases. Cancer, 1994, 73(9):2275-2279. https://doi.org/10.1002/1097-0142(19940501)73:9<2275::a id-cncr2820730907>3.0.co;2-t PMID: 7513247

[374] Nagahara T, Shiraha H, Sawahara H, Uchida D, Takeuchi $Y$, Iwamuro M, Kataoka J, Horiguchi S, Kuwaki T, Onishi H, Nakamura S, Takaki A, Nouso K, Yamamoto K. Hepatic stellate cells promote upregulation of epithelial cell adhesion molecule and epithelial-mesenchymal transition in hepatic cancer cells. Oncol Rep, 2015, 34(3):1169-1177. https:// doi.org/10.3892/or.2015.4126 PMID: 26165819 PMCID: PMC4530901

[375] Paik SY, Park YN, Kim H, Park C. Expression of transforming growth factor-beta1 and transforming growth factor-beta receptors in hepatocellular carcinoma and dysplastic nodules. Mod Pathol, 2003, 16(1):86-96. https://doi.org/10.1097/01. MP.0000047308.03300.9C PMID: 12527718

[376] Hernanda PY, Chen K, Das AM, Sideras K, Wang W, Li J, Cao W, Bots SJA, Kodach LL, de Man RA, ljzermans JNM Janssen HLA, Stubbs AP, Sprengers D, Bruno MJ, Metselaar HJ, ten Hagen TLM, Kwekkeboom J, Peppelenbosch MP, Pan Q. SMAD4 exerts a tumor-promoting role in hepatocellular carcinoma. Oncogene, 2015, 34(39):50555068. https://doi.org/10.1038/onc.2014.425 PMID: 25531314
[377] Copple BL. Hypoxia stimulates hepatocyte epithelial to mesenchymal transition by hypoxia-inducible factor and transforming growth factor- $\beta$-dependent mechanisms. Liver Int, 2010, 30(5):669-682. https://doi.org/10.1111/j.1478-32 31.2010.02205.x PMID: 20158611 PMCID: PMC3111074

[378] Caja L, Dituri F, Mancarella S, Caballero-Diaz D, Moustakas A, Giannelli G, Fabregat I. TGF- $\beta$ and the tissue microenvironment: relevance in fibrosis and cancer. Int $\mathrm{J}$ Mol Sci, 2018, 19(5):1294. https://doi.org/10.3390/ijms19051294 PMID: 29701666 PMCID: PMC5983604

[379] Eiró N, Vizoso FJ. Importance of tumor/stroma interactions in prognosis of hepatocellular carcinoma. Hepatobiliary Surg Nutr, 2014, 3(2):98-101. https://doi.org/10.3978/j.issn.2304 -3881.2014.02.12 PMID: 24812604 PMCID: PMC3999424

[380] Kubo N, Araki K, Kuwano H, Shirabe K. Cancer-associated fibroblasts in hepatocellular carcinoma. World J Gastroenterol, 2016, 22(30):6841-6850. https://doi.org/10.3748/wjg.v22.i30. 6841 PMID: 27570421 PMCID: PMC4974583

[381] Efimova EA, Glanemann M, Liu L, Schumacher G, Settmacher U, Jonas S, Langrehr JM, Neuhaus P, Nüssler AK. Effects of human hepatocyte growth factor on the proliferation of human hepatocytes and hepatocellular carcinoma cell lines. Eur Surg Res, 2004, 36(5):300-307. https://doi.org/ 10.1159/000079915 PMID: 15359093

[382] Suzuki A, Hayashida M, Kawano H, Sugimoto K, Nakano T, Shiraki K. Hepatocyte growth factor promotes cell survival from Fas-mediated cell death in hepatocellular carcinoma cells via Akt activation and Fas-death-inducing signaling complex suppression. Hepatology, 2000, 32(4 Pt 1):796802. https://doi.org/10.1053/jhep.2000.17738 PMID: 11003625

[383] Boix L, Rosa JL, Ventura F, Castells A, Bruix J, Rodés J, Bartrons R. c-met mRNA overexpression in human hepatocellular carcinoma. Hepatology, 1994, 19(1):88-91. https:// doi.org/10.1002/hep.1840190115 PMID: 8276372

[384] Okano J, Shiota G, Kawasaki H. Expression of hepatocyte growth factor (HGF) and HGF receptor (c-met) proteins in liver diseases: an immunohistochemical study. Liver, 1999, 19(2):151-159. https://doi.org/10.1111/j.1478-3231.1999.tb 00025.x PMID: 10220746

[385] Ueki T, Fujimoto J, Suzuki T, Yamamoto H, Okamoto E. Expression of hepatocyte growth factor and its receptor c-met proto-oncogene in hepatocellular carcinoma. Hepatology, 1997, 25(4):862-866. https://doi.org/10.1002/hep.510250413 PMID: 9096589

[386] Kaposi-Novak P, Lee JS, Gòmez-Quiroz L, Coulouarn C, Factor VM, Thorgeirsson SS. Met-regulated expression signature defines a subset of human hepatocellular carcinomas with poor prognosis and aggressive phenotype. J Clin Invest, 2006, 116(6):1582-1595. https://doi.org/10.1172/JCI27236 PMID: 16710476 PMCID: PMC1462944

[387] Yu G, Jing Y, Kou X, Ye F, Gao L, Fan Q, Yang Y, Zhao Q, Li R, Wu M, Wei L. Hepatic stellate cells secreted hepatocyte growth factor contributes to the chemoresistance of hepatocellular carcinoma. PLoS One, 2013, 8(9):e73312. https://doi.org/10.1371/journal.pone.0073312 PMID: 24023859 PMCID: PMC3759390

[388] Kopitz C, Gerg M, Bandapalli OR, Ister D, Pennington CJ, Hauser S, Flechsig C, Krell HW, Antolovic D, Brew K, Nagase $H$, Stangl M, von Weyhern $C W H$, Brücher BLDM, Brand K, Coussens LM, Edwards DR, Krüger A. Tissue inhibitor of metalloproteinases-1 promotes liver metastasis by induction of hepatocyte growth factor signaling. Cancer Res, 2007, 67(18):8615-8623. https://doi.org/10.1158/000 8-5472.CAN-07-0232 PMID: 17875701

[389] Schelter F, Grandl M, Seubert B, Schaten S, Hauser S, Gerg M, Boccaccio C, Comoglio P, Krüger A. Tumor cellderived Timp-1 is necessary for maintaining metastasispromoting Met-signaling via inhibition of Adam-10. Clin Exp Metastasis, 2011, 28(8):793-802. https://doi.org/10.1007/ s10585-011-9410-z PMID: 21789719

[390] Dapito DH, Mencin A, Gwak GY, Pradere JP, Jang MK, Mederacke I, Caviglia JM, Khiabanian H, Adeyemi A, Bataller R, Lefkowitch JH, Bower M, Friedman R, Sartor RB, Rabadan R, Schwabe RF. Promotion of hepatocellular carcinoma by the intestinal microbiota and TLR4. Cancer Cell, 2012, 21(4):504-516. https://doi.org/10.1016/j.ccr.2012.02.007 PMID: 22516259 PMCID: PMC3332000

[391] Darnaud M, Faivre J, Moniaux N. Targeting gut flora to prevent progression of hepatocellular carcinoma. J Hepatol, 2013, 58(2):385-387. https://doi.org/10.1016/j.jhep.2012.08. 019 PMID: 22940407 
[392] Corpechot C, Barbu V, Wendum D, Kinnman N, Rey C Poupon R, Housset C, Rosmorduc O. Hypoxia-induced VEGF and collagen I expressions are associated with angiogenesis and fibrogenesis in experimental cirrhosis. Hepatology, 2002 35(5):1010-1021. https://doi.org/10.1053/jhep.2002.32524 PMID: 11981751

[393] Aleffi S, Petrai I, Bertolani C, Parola M, Colombatto S, Novo E, Vizzutti F, Anania FA, Milani S, Rombouts K, Laffi G Pinzani M, Marra F. Upregulation of proinflammatory and proangiogenic cytokines by leptin in human hepatic stellate cells. Hepatology, 2005, 42(6):1339-1348. https://doi.org/ 10.1002/hep.20965 PMID: 16317688

[394] Taura K, De Minicis S, Seki E, Hatano E, Iwaisako K, Osterreicher $\mathrm{CH}$, Kodama Y, Miura K, Ikai I, Uemoto S, Brenner DA. Hepatic stellate cells secrete angiopoietin 1 that induces angiogenesis in liver fibrosis. Gastroenterology, 2008, 135(5):1729-1738. https://doi.org/10.1053/j.gastro.2008. 07.065 PMID: 18823985

[395] Sancho-Bru P, Juez E, Moreno M, Khurdayan V, MoralesRuiz M, Colmenero J, Arroyo V, Brenner DA, Ginès $P$, Bataller R. Hepatocarcinoma cells stimulate the growth, migration and expression of pro-angiogenic genes in human hepatic stellate cells. Liver Int, 2010, 30(1):31-41. https:// doi.org/10.1111/j.1478-3231.2009.02161.x PMID: 19929904

[396] Lin N, Chen Z, Lu Y, Li Y, Hu K, Xu R. Role of activated hepatic stellate cells in proliferation and metastasis of hepatocellular carcinoma. Hepatol Res, 2015, 45(3):326-336. https:// doi.org/10.1111/hepr.12356 PMID: 24827154

[397] Torimura T, Ueno T, Kin M, Harada R, Taniguchi E, Nakamura $T$, Sakata $R$, Hashimoto $O$, Sakamoto $M$, Kumashiro R, Sata M, Nakashima O, Yano H, Kojiro M Overexpression of angiopoietin-1 and angiopoietin-2 in hepatocellular carcinoma. J Hepatol, 2004, 40(5):799-807. https://doi.org/10.1016/j.jhep.2004.01.027 PMID: 15094228

[398] Qu H, Yang X. Metformin inhibits angiogenesis induced by interaction of hepatocellular carcinoma with hepatic stellate cells. Cell Biochem Biophys, 2015, 71(2):931-936. https:// doi.org/10.1007/s12013-014-0287-8 PMID: 25326336

[399] Bianchi G, Borgonovo G, Pistoia V, Raffaghello L. Immunosuppressive cells and tumour microenvironment: focus on mesenchymal stem cells and myeloid derived suppressor cells. Histol Histopathol, 2011, 26(7):941-951. https://doi.org/ 10.14670/HH-26.941 PMID: 21630223

[400] Brahmer JR, Drake CG, Wollner I, Powderly JD, Picus J, Sharfman WH, Stankevich E, Pons A, Salay TM, McMiller TL, Gilson MM, Wang C, Selby M, Taube JM, Anders R, Chen L, Korman AJ, Pardoll DM, Lowy I, Topalian SL. Phase I study of single-agent anti-programmed death-1 (MDX-1106) in refractory solid tumors: safety, clinical activity, pharmacodynamics, and immunologic correlates. J Clin Oncol, 2010 28(19):3167-3175. https://doi.org/10.1200/JCO.2009.26.7609 PMID: 20516446 PMCID: PMC4834717

[401] Sznol M, Powderly JD, Smith DC, Brahmer JR, Drake CG, McDermott DF, Lawrence DP, Wolchok JD, Topalian SL, Lowy I. Safety and antitumor activity of biweekly MDX-1106 (Anti-PD-1, BMS-936558/ONO-4538) in patients with advanced refractory malignancies. J Clin Oncol, 2010, 28(15 Suppl): 2506. https://doi.org/10.1200/jco.2010.28.15_suppl.2506

[402] Xia YH, Wang ZM, Chen RX, Ye SL, Sun RX, Xue Q, Huang $Y$. T-cell apoptosis induced by intratumoral activated hepatic stellate cells is associated with lung metastasis in hepatocellular carcinoma. Oncol Rep, 2013, 30(3):11751184. https://doi.org/10.3892/or.2013.2571 PMID: 23807027

[403] Zhao W, Zhang L, Xu Y, Zhang Z, Ren G, Tang K, Kuang P, Zhao B, Yin Z, Wang X. Hepatic stellate cells promote tumor progression by enhancement of immunosuppressive cells in an orthotopic liver tumor mouse model. Lab Invest 2014, 94(2):182-191. https://doi.org/10.1038/labinvest.2013. 139 PMID: 24296878
[404] Xia YH, Lu Z, Zhao M, Dai WT, Ding L, Hu LX, Jiang GJ. Tumor-specific hepatic stellate cells (tHSCs) induce DIgR2 expression in dendritic cells to inhibit T cells. Oncotarget, 2017, 8(33):55084-55093. https://doi.org/10.18632/oncotar get.19027 PMID: 28903404 PMCID: PMC5589643

[405] Sulpice L, Rayar M, Desille M, Turlin B, Fautrel A, Boucher E, Llamas-Gutierrez F, Meunier B, Boudjema K, Clément B, Coulouarn C. Molecular profiling of stroma identifies osteopontin as an independent predictor of poor prognosis in intrahepatic cholangiocarcinoma. Hepatology, 2013, 58(6): 1992-2000. https://doi.org/10.1002/hep.26577 PMID: 23775819

[406] Xiao X, Gang Y, Gu Y, Zhao L, Chu J, Zhou J, Cai X, Zhang $\mathrm{H}, \mathrm{Xu}$ L, Nie Y, Wu K, Liu Z, Fan D. Osteopontin contributes to TGF- $\beta 1$ mediated hepatic stellate cell activation. Dig Dis Sci, 2012, 57(11):2883-2891. https://doi.org/10.10 07/s10620-012-2248-7 PMID: 22661273

[407] Gentilini A, Rombouts K, Galastri S, Caligiuri A, Mingarelli E, Mello T, Marra F, Mantero S, Roncalli M, Invernizzi $P$, Pinzani M. Role of the stromal-derived factor-1 (SDF-1)CXCR4 axis in the interaction between hepatic stellate cells and cholangiocarcinoma. J Hepatol, 2012, 57(4):813-820. https://doi.org/10.1016/j.jhep.2012.06.012 PMID: 22727731

[408] Okamoto K, Tajima H, Nakanuma S, Sakai S, Makino I, Kinoshita J, Hayashi H, Nakamura K, Oyama K, Nakagawara H, Fujita $\mathrm{H}$, Takamura H, Ninomiya I, Kitagawa H, Fushida S, Fujimura T, Harada S, Wakayama T, Iseki S, Ohta T. Angiotensin II enhances epithelial-to-mesenchymal transition through the interaction between activated hepatic stellate cells and the stromal cell-derived factor-1/CXCR4 axis in intrahepatic cholangiocarcinoma. Int J Oncol, 2012, 41(2): 573-582. https://doi.org/10.3892/ijo.2012.1499 PMID: 22664794

[409] Chuaysri C, Thuwajit P, Paupairoj A, Chau-In S, Suthiphongchai T, Thuwajit C. Alpha-smooth muscle actin-positive fibroblasts promote biliary cell proliferation and correlate with poor survival in cholangiocarcinoma. Oncol Rep, 2009, 21(4):957-969. https://doi.org/10.3892/or_00000309 PMID: 19287994

[410] Kim Y, Kim MO, Shin JS, Park SH, Kim SB, Kim J, Park SC, Han CJ, Ryu JK, Yoon YB, Kim YT. Hedgehog signaling between cancer cells and hepatic stellate cells in promoting cholangiocarcinoma. Ann Surg Oncol, 2014, 21(8):26842698. https://doi.org/10.1245/s10434-014-3531-y PMID: 24682719

[411] Schuppan D, Ashfaq-Khan M, Yang AT, Kim YO. Liver fibrosis: direct antifibrotic agents and targeted therapies. Matrix Biol, 2018, 68-69:435-451. https://doi.org/10.1016/ j.matbio.2018.04.006 PMID: 29656147

[412] Friedman S, Sanyal A, Goodman Z, Lefebvre E, Gottwald M, Fischer L, Ratziu V. Efficacy and safety study of cenicriviroc for the treatment of non-alcoholic steatohepatitis in adult subjects with liver fibrosis: CENTAUR Phase $2 \mathrm{~b}$ study design. Contemp Clin Trials, 2016, 47:356-365. https://doi.org/10. 1016/j.cct.2016.02.012 PMID: 26944023

[413] Narra K, Mullins SR, Lee HO, Strzemkowski-Brun B Magalong K, Christiansen VJ, McKee PA, Egleston B, Cohen SJ, Weiner LM, Meropol NJ, Cheng JD. Phase II trial of single agent Val-boroPro (Talabostat) inhibiting fibroblast activation protein in patients with metastatic colorectal cancer. Cancer Biol Ther, 2007, 6(11):1691-1699. https://doi.org/ 10.4161/ cbt.6.11.4874 PMID: 18032930

[414] Kelly T. Fibroblast activation protein-alpha and dipeptidyl peptidase IV (CD26): cell-surface proteases that activate cell signaling and are potential targets for cancer therapy. Drug Resist Updat, 2005, 8(1-2):51-58. https://doi.org/10. 1016/j.drup.2005.03.002 PMID: 15939342

[415] Ingham PW, Nakano Y, Seger C. Mechanisms and functions of Hedgehog signalling across the metazoa. Nat Rev Genet, 2011, 12(6):393-406. https://doi.org/10.1038/nrg2984 PMID: 21502959

\section{Corresponding author}

Carmen Stanca Melincovici, Lecturer, MD, PhD, Discipline of Histology, Department of Morphological Sciences, luliu Haţieganu University of Medicine and Pharmacy, 4-6 Louis Pasteur Street, 400349 Cluj-Napoca, Romania; Phone +40740-219 735, e-mail: cmelincovici@yahoo.com 